\title{
Geology of an Upper Cretaceous Copper Deposit in the Andean Province, Lassiter Coast, Antarctic Peninsula
}

GEOLOGICAL SURVEY PROFESSIONAL PAPER 984

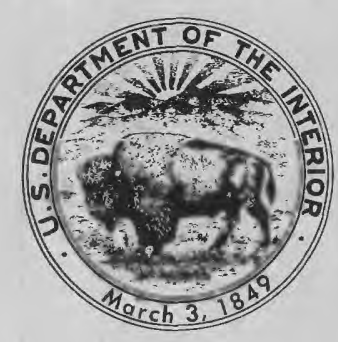



GEOLOGY OF AN

UPPER GRETACEOUS COPPER DEPOSIT

IN THE ANDEAN PROVINCE,

LASSITER COAST, ANTARCTIC PENINSULA 


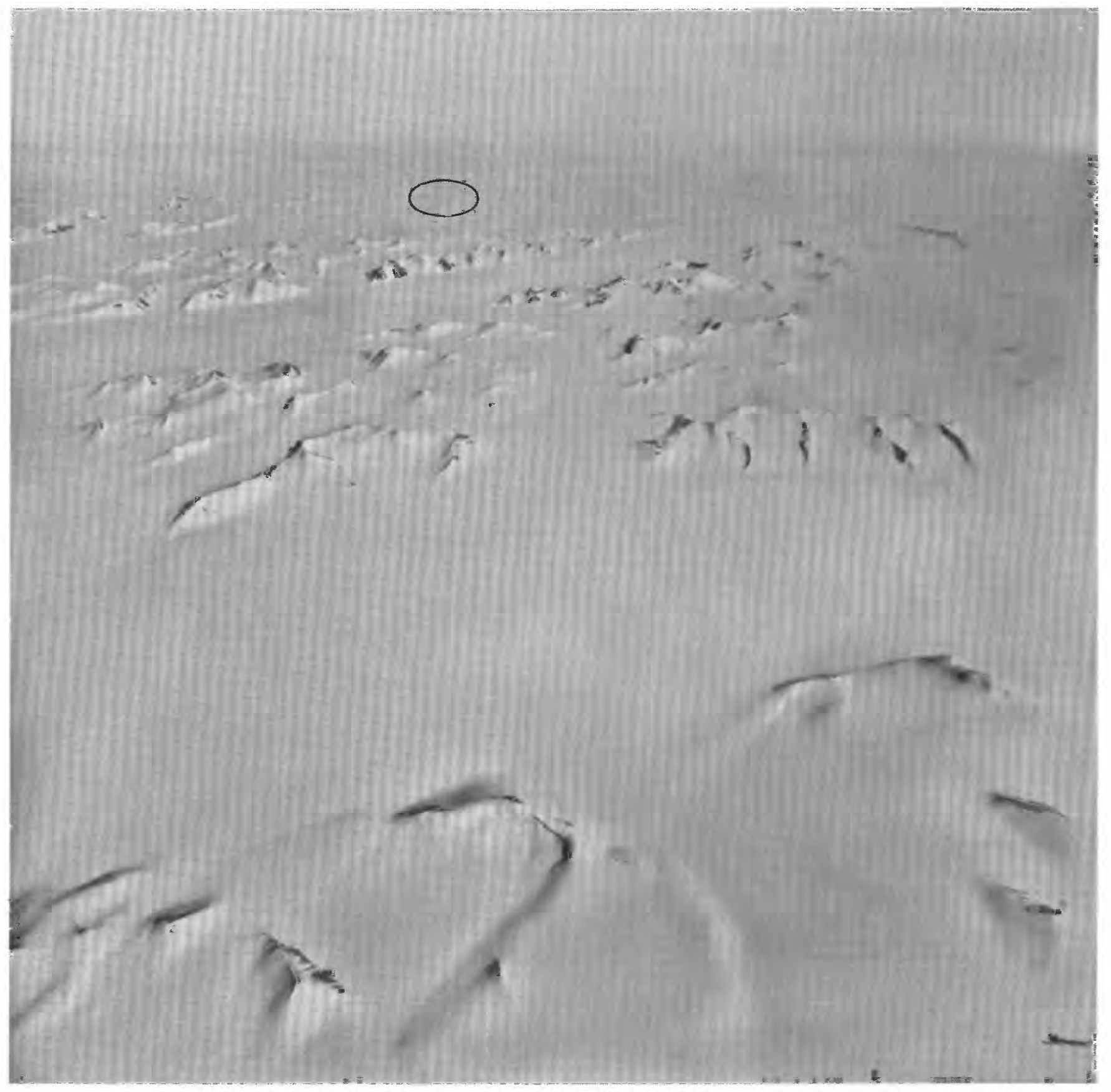

Physiographic setting of the Copper Nunataks (circled). View westsouthwest toward the Antarctic Peninsula ice plateau in the background. Western part of the Hutton Mountains in the forground; Johnston glacier separates these mountains from the
Guettard Range in the middleground. The narrow RARE Range lies beyond the well-defined 6-km-wide Irvine Glacier, and it is separated by the Wetmore Glacier from several nunatak clusters of the Latady Mountains in the left background. 


\section{Geology of an Upper Cretaceous Copper Deposit in the Andean Province, Lassiter Coast, Antarctic Peninsula}

By Peter D. Rowley, Paul L. Williams, and Dwight L. Schmidt

GE O L O I C A L S U R V E Y PR OFES I O N A L PA PER 984

Work done in cooperation with

the National Science Foundation

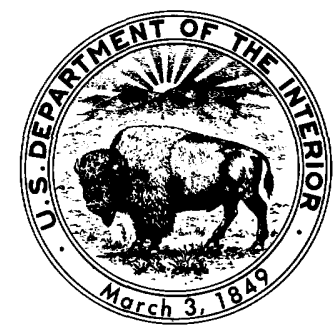

A discussion of the southernmost known

circum-Pacific copper deposit, which has

affinities to the porphyry copper class

but has no present economic potential 


\title{
UNITED STATES DEPARTMENT OF THE INTERIOR
}

\author{
CECIL D. ANDRUS, Secretary
}

\section{GEOLOGICAL SURVEY}

\author{
V. E. McKelvey, Director
}

Library of Congress Cataloging in Publication Data

Rowley, Peter D.

Geology of an Upper Cretaceous copper deposit in the Andean Province, Lassiter Coast, Antarctic Peninsula.

(Geological Survey Professional Paper 984)

Bibliography: $p$.

1. Copper ores-Antarctic regions-Lassiter Coast. 2. Geology-Antarctic regions-Lassiter Coast. 3. Geology, StratigraphicCretaceous. I. Williams, Paul Lincoln, 1932- joint author. II. Schmidt, Dwight Lyman, 1926- joint author. III. United States, National Science Foundation. IV. Title: Geology of an Upper Cretaceous copper deposit in the Andean Province... V. Series: United States Geological Survey Professional Paper 984.

$\begin{array}{lr}\text { QE390.2.C6R68 } & 549^{\prime} .23\end{array}$

$76-45929$

For sale by the Superintendent of Documents, U.S. Government Printing Office

Washington, D.C. 20402

Stock Number 024-001-02955-3 


\section{CONTENTS}

\begin{tabular}{|c|c|}
\hline Page & Page \\
\hline Abstract_ & Older shear fracturing, hydrothermal alteration, and mineraliza- \\
\hline troduction & tion \\
\hline Acknowledgments -- & Younger shear fracturing, hydrothermal alteration, and mineral- \\
\hline Igneous rocks & ization \\
\hline Medium-grained granodiorite pluton & Mineralization \\
\hline Aplite and pegmatite dikes & Phyllic and argillic alteration... \\
\hline Dacite dike & Propylitic alteration \\
\hline Copper Nunataks pluton & Epidote alteration \\
\hline Aplite and pegmatite dikes & Silicification \\
\hline Granodiorite porphyry dikes & Mineralized and altered rock elsewhere in the Lassiter Coast and \\
\hline Interpretation of the chemical and modal data & southern Black Coast \\
\hline Trends of systematic joints & Conclusions - \\
\hline & \\
\hline
\end{tabular}

\section{ILLUSTRATIONS}

FrontisPiECE. Photograph showing physiographic setting of the Copper Nunataks.

Figures 1-4. Maps of:

1. West Antarctica showing location of Lassiter Coast project area and Copper Nunataks

2. Lassiter Coast and southern Black Coast showing locations of known mineralized and hydrothermally altered rock

3. The Copper Nunataks showing generalized geology

4. Three of the Copper Nunataks showing the geologic features

5. Ternary diagram showing modal distribution of quartz, K-feldspar, and plagioclase from igneous rocks in the Copper

Nunataks _...

6. Maps showing sample localities and outcrops in the Copper Nunataks

7. Photograph of Nunatak B

8. Photomicrograph of granodiorite pluton _...

9. Photograph of mafic inclusion, aplite dikes, and gray shear fractures cutting granodiorite pluton

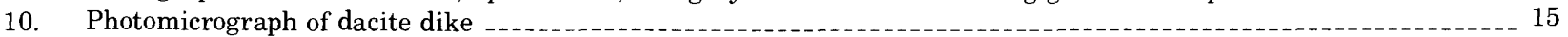

11. Photograph showing a typical outcrop of Copper Nunataks pluton, Nunatak A

12. Photograph showing a typical outcrop of Copper Nunataks pluton, Nunatak D

13. Closeup photograph of outcrop of Copper Nunataks pluton, Nunatak D

14. Photomicrographs of Copper Nunataks pluton, Nunataks B and E

15. Photograph of aplite dikes in a stoped block in the granodiorite pluton, Nunatak A

16. Photomicrograph of chilled margins of granodiorite porphyry dike

17. Photomicrograph of interior of granodiorite porphyry dike

18. Variation diagram of common oxides, selected trace elements, and differentiation index plotted against $\mathrm{SiO}_{2}$ in specimens from igneous rocks in the Copper Nunataks _...

19. Ternary plots of selected normative minerals, Barth's cations, and oxides in specimens from igneous rocks in the Copper Nunataks -

20. Rose diagram of strikes of systematic steeply dipping joints in rocks in the Copper Nunataks

21. Photograph of granodiorite pluton and pegmatite dikes offset by several black shear fractures

22. Photomicrograph of black shear fracture _...

23. Photographs of sheared phyllic-argillic zones, Nunataks A, B, and C

24-29. Photomicrographs of altered rock:

24. Phyllic altered rock of the granodiorite pluton

25. Phyllic altered rock of the granodiorite porphyry dike

26. Sheared and phyllic altered rock of the Copper Nunataks pluton

27. Argillic altered rock of the Copper Nunataks pluton

28. Propylitic altered rock of the granodiorite pluton

29. Silicified rock of the granodiorite pluton 


\section{TABLES}

TABLE

Modes of fresh igneous rocks in Copper Nunataks, Antarctica Page

10

2. Chemical and modal data of selected fresh rocks from the major rock units from the Copper Nunataks, Antarctica

3. Semiquantitative spectrographic analyses of selected fresh, altered, and mineralized rock from the Copper Nunataks, Antarctica

4. Results of X-ray determination of sheet silicates from hydrothermally altered rocks of the Copper Nunataks, Antarc-

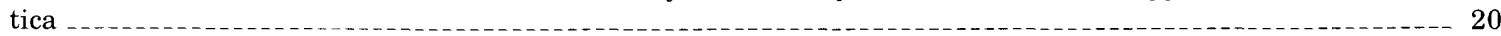

5. Semiquantitative spectrographic analyses of biotite-hornblende separates from fresh igneous rocks in the Copper Nunataks, Antarctica _......

6. Semiquantitative spectrographic analyses of selected fresh, altered, and mineralized rock from scattered locations elsewhere in the Lassiter Coast and southern Black Coast 


\title{
GEOLOGY OF AN UPPER CRETACEOUS COPPER DEPOSIT IN THE ANDEAN PROVINCE, LASSITER COAST, ANTARCTIC PENINSULA
}

\author{
By Peter D. Rowley, Paul L. Williams, and Dwight L. Schmidt
}

\begin{abstract}
Mineralization with affinities to the porphyry copper class terminated two Upper Cretaceous episodes of similar igneous-tectonic events in the Copper Nunataks area of the Lassiter Coast, Antarctica. The first episode, at about 105 m.y. (million years), began with intrusion of a medium-grained granodiorite batholith, followed by emplacement of thin hornblende dacite dikes, and ended with two events of fracturing accompanied by minor hydrothermal alteration and pyrite mineralization. The second episode, at about 95 m.y., began with intrusion of a coarse-grained and mostly porphyritic, concentrically zoned quartz monzonite stock (Copper Nunataks pluton), followed by emplacement of 1 - to 20 -m-wide granodiorite porphyry dikes, and ended with extensive shearing accompanied by major hydrothermal alteration and copper mineralization (Lassiter Coast copper deposit). Altered rock associated with the second episode occurs along northwest-striking sheared phyllic-argillic zonés, between which is propylitic-altered rock. Mineralization, in the same location as propylitic, argillic, and phyllic rock, produced quartz veins, fist-size clots of chalcopyrite and pyrite, and disseminated crystals of chalcopyrite and pyrite. The main ore minerals are chalcopyrite, pyrite, and magnetite; malachite, molybdenite, hematite-limonite, and apparently chalococite are less abundant. Average mineral grade of exposed rock probably does not exceed $200 \mathrm{ppm} \mathrm{Cu}$, $100 \mathrm{ppm} \mathrm{Pb}$, and $50 \mathrm{ppm}$ Mo. Thus there is no evidence that the deposit is of ore grade even if it were feasible to be mined, but its discovery demonstrates that the Antarctic Peninsula may be placed within the circum-Pacific copper province. The presence of the occurrence suggests the possibility of undiscovered copper deposits of economic grade elsewhere in the peninsula.
\end{abstract}

\section{INTRODUCTION}

The world's southernmost occurrence of significant copper minerals was discovered in the Lassiter Coast area of Antarctica by D. L. Schmidt and L. E. Brown during the 1969-70 austral summer field season. Exposures occur in the Copper Nunataks, ${ }^{1}$ a small cluster of rock hills about $10 \mathrm{~km}$ west of the RARE (Ronne Antarctic Research Expedition) Range near the crest of the ice plateau $(2,000 \mathrm{~m}$ elevation) of the Antarctic Peninsula about $130 \mathrm{~km}$ west of the Weddell Sea (fig. 1). A more detailed field study was conducted during 5 days of the 1970-71 season by P. L. Williams (party leader), P. D. Rowley, R. L. Reynolds, and A. B. Ford.

\footnotetext{
${ }^{1}$ Name recommended for initial approval by Advisory Committee on Antarctic Names.
}

This report presents the results of field studies, detailed petrographic studies, and chemical analyses.

The Antarctic Peninsula is a geologic continuation of the Chilean and Patagonian Andes (Adie, 1955, 1964; Halpern, 1971; Ford, 1972; Dalziel and Elliot, 1973), but the continuation of this Andean orogen south of the Antarctic Peninsula is more uncertain. Evidence such as a sharp westward bend in the structure at the south base of the Antarctic Peninsula (Laudon, 1972; Laudon and others, 1969) and some similarities between the rocks of the peninsula and those of western Ellsworth

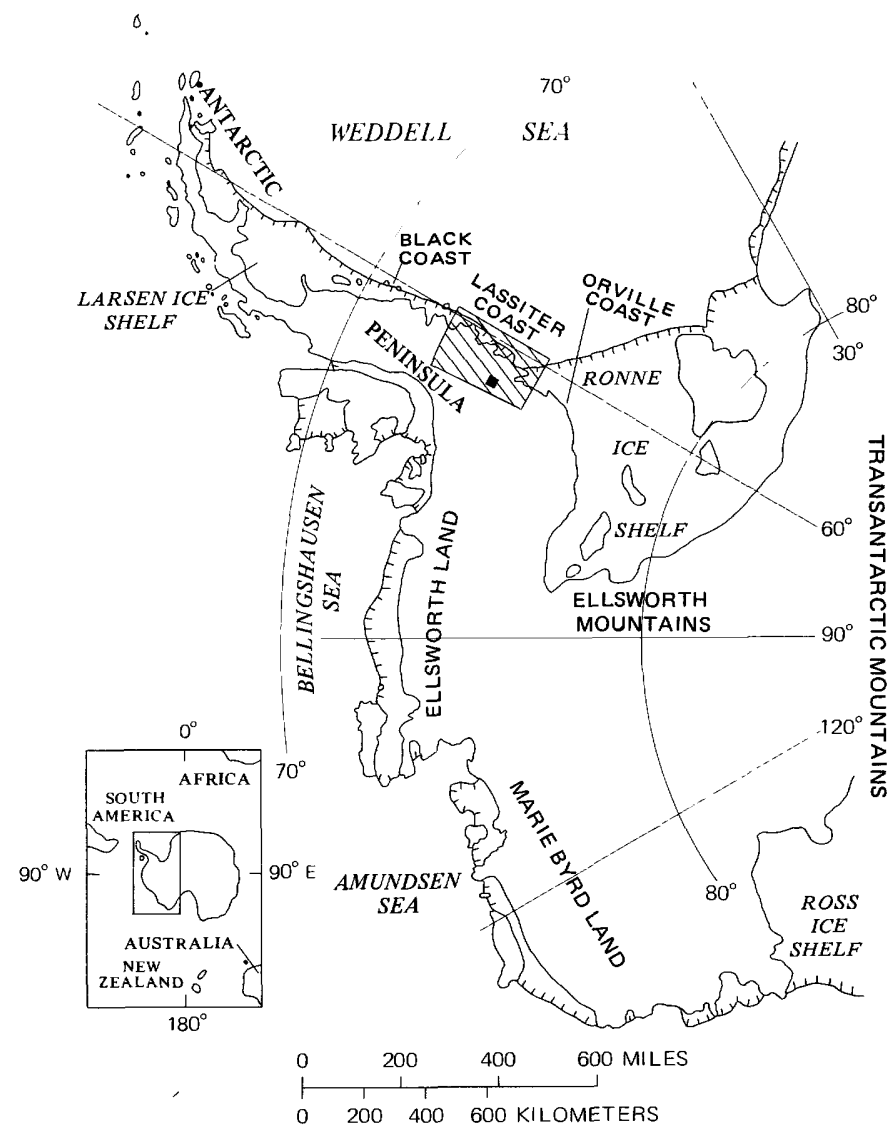

Figure 1.-West Antarctica, showing location of Lassiter Coast project area (diagonal ruling) and Copper Nunataks (black square). 
Land and Marie Byrd Land (for example, Wade, 1969) suggests that the orogen passes through these parts of West Antarctica (Craddock, 1970a, 1972; Halpern, 1971). Geologic similarities suggest that this belt, which is the southern loop of the great circum-Pacific mountain chain, may extend through New Zealand (Craddock, 1970b; Elliot, 1972; Bradshaw and Andrews, 1973) and into the western Pacific area.

The geology of the Antarctic Peninsula has been summarized by Adie $(1964,1969)$. He and other workers noted that calc-alkaline stocks and batholiths of the Cretaceous and Tertiary Andean intrusive suite (Adie, 1955) dominate the geology of the Antarctic Peninsula. Plutons of this suite intrude (1) a lower Paleozoic(?) basement complex of igneous and metamorphic rock (Adie, 1954), (2) a thick sequence of black sedimentary rock of the Carboniferous(?) to lower Mesozoic(?) Trinity Peninsula Series (Adie, 1957) that were probably folded in Triassic or Jurassic time, and (3) a thick sequence of black Upper Jurassic and Lower Cretaceous sedimentary rock and associated volcanic rock (Upper Jurassic) that were probably folded in Cretaceous time. Gently folded to horizontal Upper Cretaceous sedimentary rock (Bibby, 1966) and Cenozoic sedimentary and volcanic rock unconformably overlie the older rocks. Rowley and others (1975) compared the Lassiter Coast copper deposit to other metal occurrences in the Antarctic Peninsula and concluded that metallization is associated with Andean plutonic rock and that the peninsula belongs to the circum-Pacific copper province.

Reconnaissance geologic investigations over about $30,000 \mathrm{~km}^{2}$ of the Lassiter Coast, northern Orville Coast, and southern Black Coast (Williams, 1970; Williams and Rowley, 1971, 1972; Williams and others, 1972; Rowley, 1973) show that the area is part of the Andean orogen. The oldest known rocks consist of black fine-grained sedimentary rocks (Latady Formation) of Late Jurassic age (R. W. Imaly and E. G. Kauffman, written commun., 1975); these rocks have been tightly folded around northeast to northnortheast axes (Kellogg and Rowley, 1974) prior to intrusion of numerous stocks and batholiths. Metamorphic aureoles, containing grades as high as andalusite hornfels, surround the plutons (Plummer, 1974). The plutons belong to a calc-alkaline suite (Rowley and Williams, 1974) consisting largely of quartz diorite, granodiorite, and quartz monzonite but they range from gabbro to granite. Numerous occurrences of minor hydrothermally altered rock, copper sulfides, and other ore minerals are associated with the Andean plutonic rocks (fig. 2); these occurrences are discussed in the section on "Mineralized and altered rock else- where in the Lassiter Coast and southern Black Coast."

Biotite-hornblende pairs from five plutons in the southern and central Lassiter Coast yield K-Ar ages ranging between 119 and 99 m.y. (Mehnert and others, 1975). Potassium-argon ages of biotite and hornblende from eight samples of plutonic rocks in the northern Lassiter Coast and southern Black Coast range between 114 and 98 m.y. (Rowley and others, 1976). The ages agree with three K-Ar ages given below (see pp. 4, 8, and 15) for rocks from the Copper Nunataks, determined by A. H. Clark, Edward Farrar, and S. L. McBride of Queen's University, Ontario, Canada.

The Lassiter Coast copper deposit is by far the highest grade and most extensive of the mineral occurrences on the Lassiter Coast, and it is the only one that received any detailed field and laboratory investigation. It has affinities with the porphyry copper class of mineral deposits. However, the average copper content of samples from the limited exposures is probably no more than $200 \mathrm{ppm}$, well below present economic grade even for United States domestic deposits.

The bedrock in the Copper Nunataks (fig. 3) consists entirely of igneous rocks of Late Cretaceous age. The geologic history of these rocks may be divided into two broad episodes consisting of a nearly identical series of events; both episodes terminated with mineralization. Each episode consisted of intrusion of a pluton followed by emplacement of aplite and pegmatite dikes, intrusions of northwest-trending mafic porphyritic dikes, and faulting or "crackling" accompanied by mineralization and hydrothermal alteration. The mineralization and alteration during the younger episode were more intense and resulted in the Lassiter Coast copper deposit.

The well-exposed bedrock (fig. 3) in the Copper Nunataks is fresh because it was scoured during higher ice stands. Summer air temperatures extend to $-30^{\circ} \mathrm{C}$ and rarely exceed $0^{\circ} \mathrm{C}$; the humidity is extremely low, so megascopic organisms are limited to sparse patches of lichens on the rocks. Rock temperatures, however, have been recorded at above $+20^{\circ} \mathrm{C}$ for several hours a week during several weeks at midseason. Under these conditions, chemical weathering takes place very slowly (Boyer, 1975); therefore supergene minerals are scarce and most alteration and mineralization products discussed below are considered to be hypogene.

\section{ACKNOWLEDGMENTS}

This work is part of a U.S. Geological Survey geologic study of the Lassiter Coast area done under 


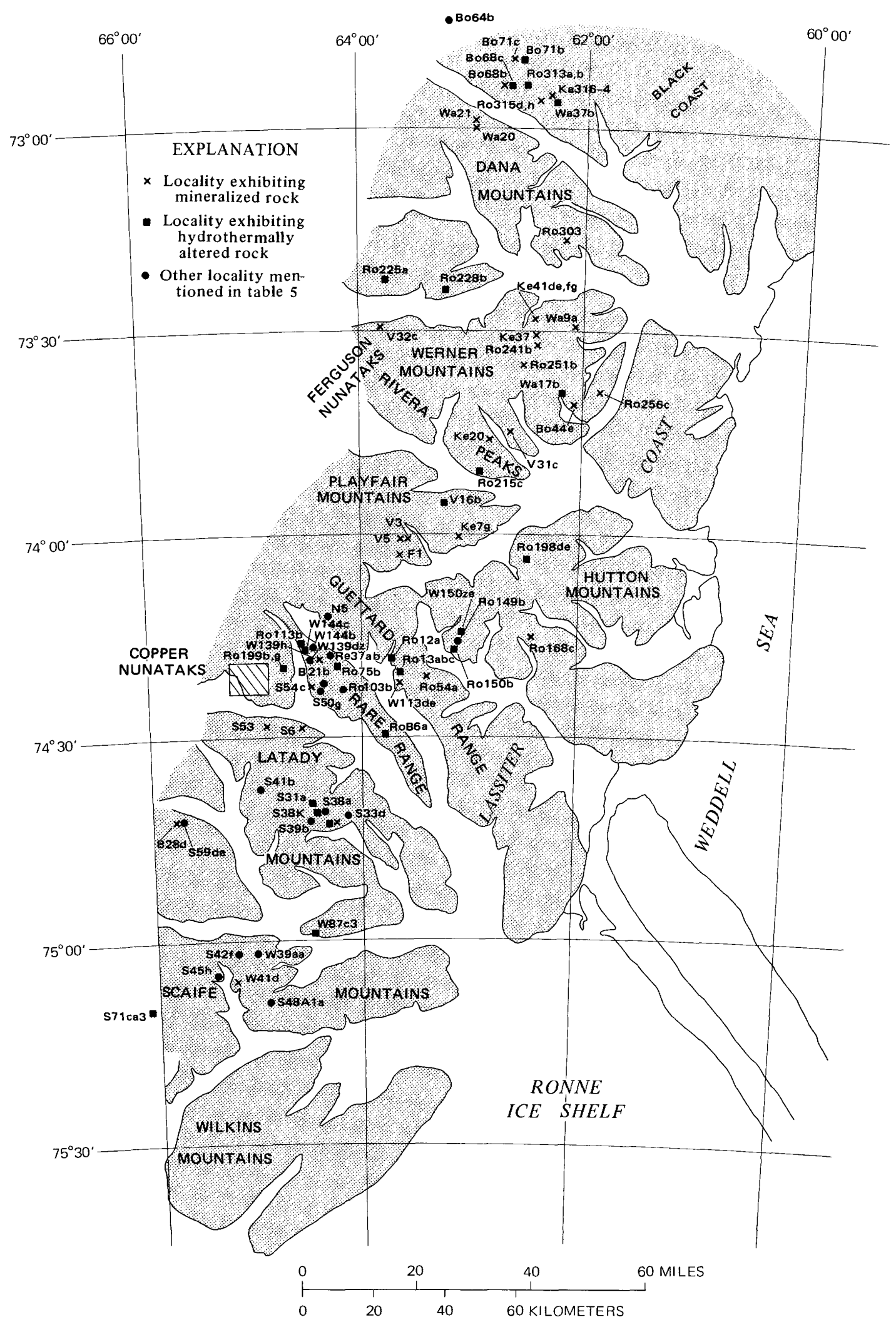

FIGURE 2.-Lassiter Coast and southern Black Coast showing locations of known mineralized and hydrothermally altered rock. 


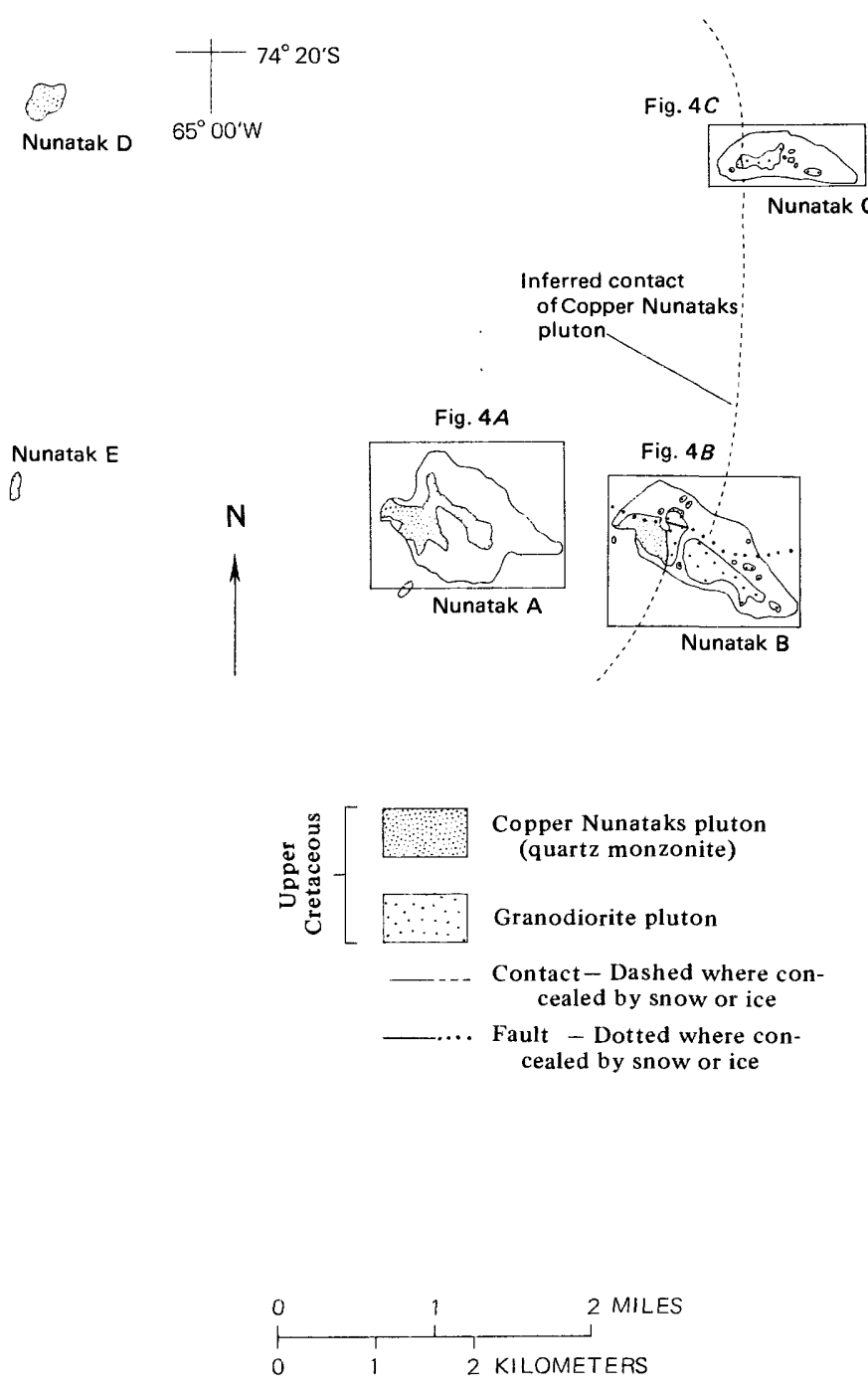

Figure 3.-Generalized geology of the Copper Nunataks.

the auspices of, and financed by, the National Science Foundation (NSF) (Grant AG-187). The U.S. Antarctic Research Program of the National Science Foundation and the U.S. Navy Operation Deep Freeze provided logistic support in Antarctica. Many persons made the study possible. The memory of the late Prof. Duncan Stewart VII of Carleton College, a former teacher, colleague, and friend, provided inspiration for this report. M. D. Turner, Program Manager of Polar Earth Sciences, Division of Polar Programs of NSF, approved the program and provided logistic help. L. E. Brown, A. B. Ford, and R. L. Reynolds of the U.S. Geological Survey aided the writers with the field mapping of the Copper Nunataks. Copper sightings elsewhere in the Lassiter Coast area were made by the other geologists during the field seasons: C. C. Plummer during the 1969-70 season, W. H. Nelson during the 1970-71 season, and S. J. Boyer, E. N. Kamenev, K. S. Kellogg,
W. R. Vennum and R. B. Waitt, Jr., during the 197273 season; all were affiliated with the U.S. Geological Survey except Kamenev, who is at the Research Institute of the Geology of the Arctic, Leningrad, USSR. Potassium-argon age dating was done by A. H. Clark, Edward Farrar, and S. L. McBride of Queen's University, Ontario, Canada. L. G. Schultz of the U.S. Geological Survey aided the senior author in X-ray identification of clay minerals and interpreted the data. Discussions with A. V. Heyl and R. U. King of the U.S. Geological Survey helped form conclusions. G. A. Desborough and D. P. Cox reviewed the manuscript.

\section{IGNEOUS ROCKS}

Rocks in the Copper Nunataks are discussed in age sequence from oldest to youngest; their distribution is shown on the geologic sketch map (fig. 4). The modal classification (fig. 5) follows Bateman (1961, fig. 2). Sample localities and outcrops are shown in figure 6 . Anorthite content of plagioclase was determined by the a-normal method using the low-temperature curves of Wahlstrom (1947, fig. 21, curve D).

\section{MEDIUM-GRAINED GRANODIORITE PLUTON}

The first event in the earliest igneous episode was intrusion of the older of two large plutons in the area. This granodiorite body is characterized by its uniform composition and texture, light- to medium-gray color due to abundant ferromagnesian minerals and dioritic inclusions, and at least minor alteration in nearly all exposures. The rock is generally nonfoliated, but in several places a vague flow foliation of ferromagnesian minerals strikes northwest. It is mostly medium grained (1-5 mm), but in some places it is gradational to fine grained. Studies by A. H. Clark, Edward Farrar, and S. L. McBride (written commun., 1974) give a $\mathrm{K}-\mathrm{Ar}$ biotite determination of $104.9 \pm 1.6 \mathrm{~m}$.y. for this pluton (specimen M308a).

The granodiorite is exposed at Nunataks A and B (figs. 4, 5, 7) as massive resistant outcrops cut by medium spaced to finely spaced joints; it underlies at least $15 \mathrm{~km}^{2}$ in the area of the five largest nunataks of figure 3. No contacts with older rocks are exposed in the area, but on the basis of similar petrology (table 1) and chemistry (table 2), the granodiorite is probably correlative with a batholith (West RARE pluton) in the western nunataks of the RARE Range about $8 \mathrm{~km}$ to the northeast. The West RARE batholith discordantly intrudes folded slate and sandstone of the Upper Jurassic Latady Formation (Williams and others, 1972), and contact metamorphism reaches andalusite hornfels grade (Plummer, 1974). Pluton contacts are commonly chilled and are accompanied by igneous apophyses in the metamorphic country rock; as else- 

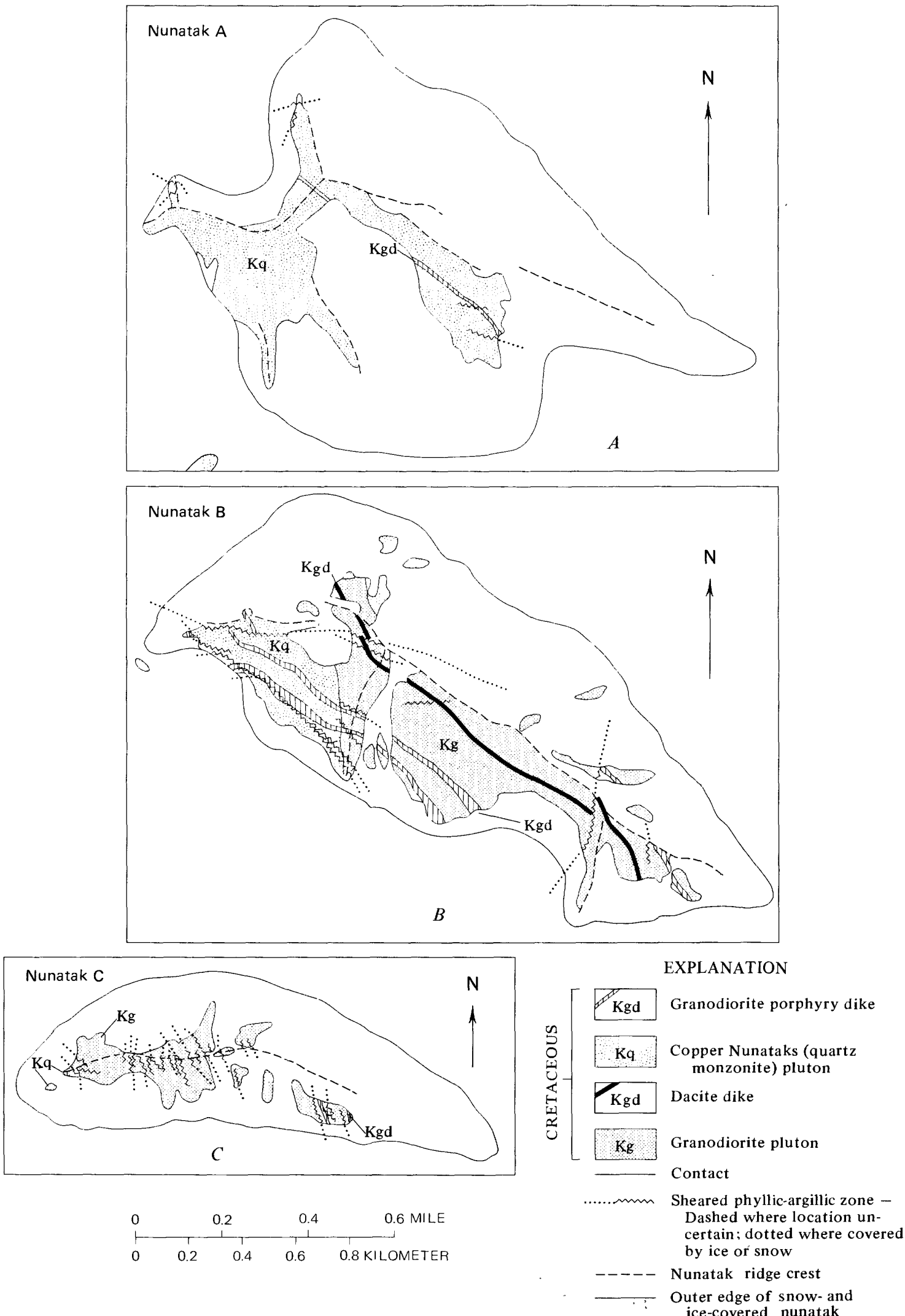

Figure 4.-Geology of three of the Copper Nunataks (fig. 3). 

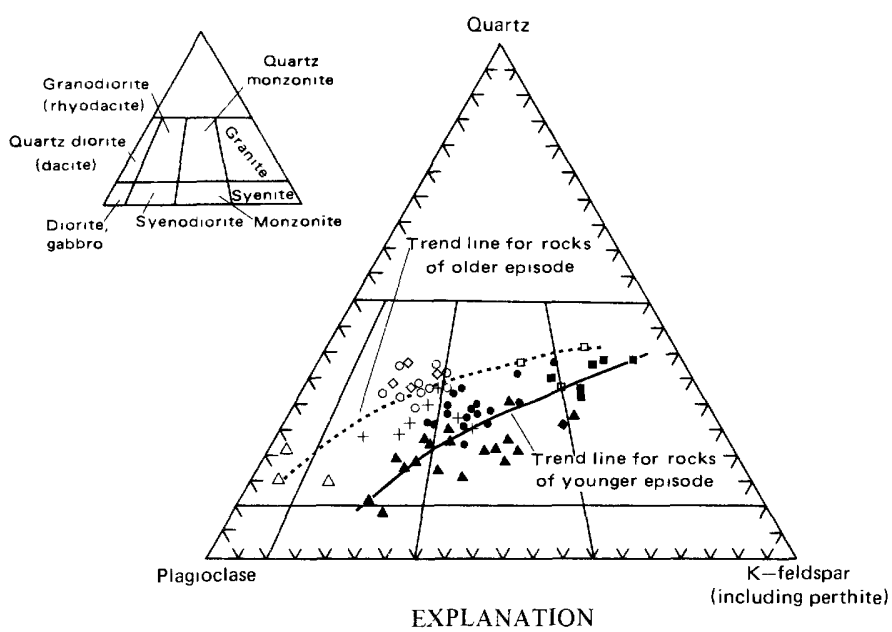

Cretaceous

Younger igneous episode

- Aplite of granodiorite porphyry dike

- Granodiorite porphyry dike

- Aplite of Copper Nunataks pluton

- Quartz monzonite of Copper Nunataks pluton

+ Assimilated rocks - Of same age as Copper Nunataks pluton

Older igneous episode

$\triangle$ Dacite dike

- Aplite of granodiorite pluton

- Granodiorite pluton

West RARE pluton - Of same age as granodiorite pluton

FIGURE 5.-Modal distribution of quartz, K-feldspar, and plagioclase in fresh rocks from the major igneous units, Copper Nunataks. Calculated from data in table 1 . Insert shows igneous classification used.

where in the Lassiter Coast, evidence supports the conclusion that the plutons originated by magmatic processes of passive to forceful intrusion. If the petrologic and age correlations are correct, the medium-grained granodiorite is at least $20 \mathrm{~km}$ long in a northeast direction and $10 \mathrm{~km}$ wide in a northwest direction.

Modal analyses for 10 samples from the mediumgrained granodiorite and their averages are presented in table 1. Plagioclase, hornblende, and biotite are subhedral in most thin sections; quartz and K-feldspar are anhedral (fig. 8). Minerals are equigranular except for scattered large inconspicuous light-gray poikilitic $\mathrm{K}$-feldspar crystals which are as much as $2 \mathrm{~cm}$ long and which enclose other minerals. Crystals other than $\mathrm{K}$-feldspar average about $1 \mathrm{~mm}$ and rarely exceed $3 \mathrm{~mm}$. K-feldspar is rarely grid-twinned; perthite is rare to absent. Most plagioclase is zoned, anorthite content in most thin sections ranges from sodic lab- radorite cores to calcic oligoclase rims. Nonzoned crystals have an average composition of intermediate andesine. In some places, the boundaries between plagioclase and K-feldspar or plagioclase and quartz contain small areas of myrmekite. Smoky quartz is abundant and has undulatory extinction in irregular masses as large as $5 \mathrm{~mm}$ across. Biotite is strongly pleochroic ( $\mathrm{X}=$ pale yellow, $\mathrm{Z}=$ dark brown to dark reddish brown). Most biotite shows at least some alteration to chlorite (penninite?) along cleavage planes and to a much lesser degree to epidote. Hornblende is also markedly pleochroic ( $\mathrm{X}=$ yellowish green, $\mathrm{Y}=$ grass green, $\mathrm{Z}=$ olive green to dark yellowish green). Content of biotite is relatively uniform, whereas the content of hornblende is quite variable. Magnetite is the most abundant opaque mineral; minor amounts of pyrite and ilmenite are present. Sphene is rare and occurs as small poorly developed crystals. Apatite and zircon are present.

A triangular plot of plagioclase, K-feldspar, and quartz (fig. 5) shows that most rocks fall in a tight cluster in the granodiorite field near the boundary with quartz monzonite. Similar data for four samples from the West RARE pluton plot in the same area in figure 5 add further support to the proposed correlation of these two rock bodies.

Three rapid rock chemical analyses and three semiquantitative spectrographic analyses of fresh rock of the granodiorite pluton and West RARE pluton are presented in tables 2 and 3 . The analyses from the granodiorite are somewhat lower in potassium and sodium and higher in calcium than the average hornblende-biotite granodiorite of Nockolds (1954). Sample W144a, representative of the West RARE pluton and from $15 \mathrm{~km}$ northwest of Nunatak C, is only slightly more silicic; it is lower in potassium and sodium and higher in calcium than Nockolds' average granodiorite. Trace elements of sample W144a have concentrations similar to those of the medium-grained granodiorite.

The plutonic rock contains many medium- to darkgreenish-gray, ovoid to subspherical inclusions that average $5 \mathrm{~cm}$ in diameter; some exceed $1 \mathrm{~m}$ in diameter (fig. 9). Exposures average three or four inclusions per $\mathrm{m}^{2}$ of outcrop face, but in some places inclusions constitute more than 5 percent of rock volume. Mafic inclusions are remarkably uniform in texture, composition, and size within each pluton; most inclusions are fine-grained rocks (average crystal size less than $1 \mathrm{~mm}$ ), with or without phenocrysts of plagioclase, hornblende, and (or) biotite. Inclusion edges are mostly 

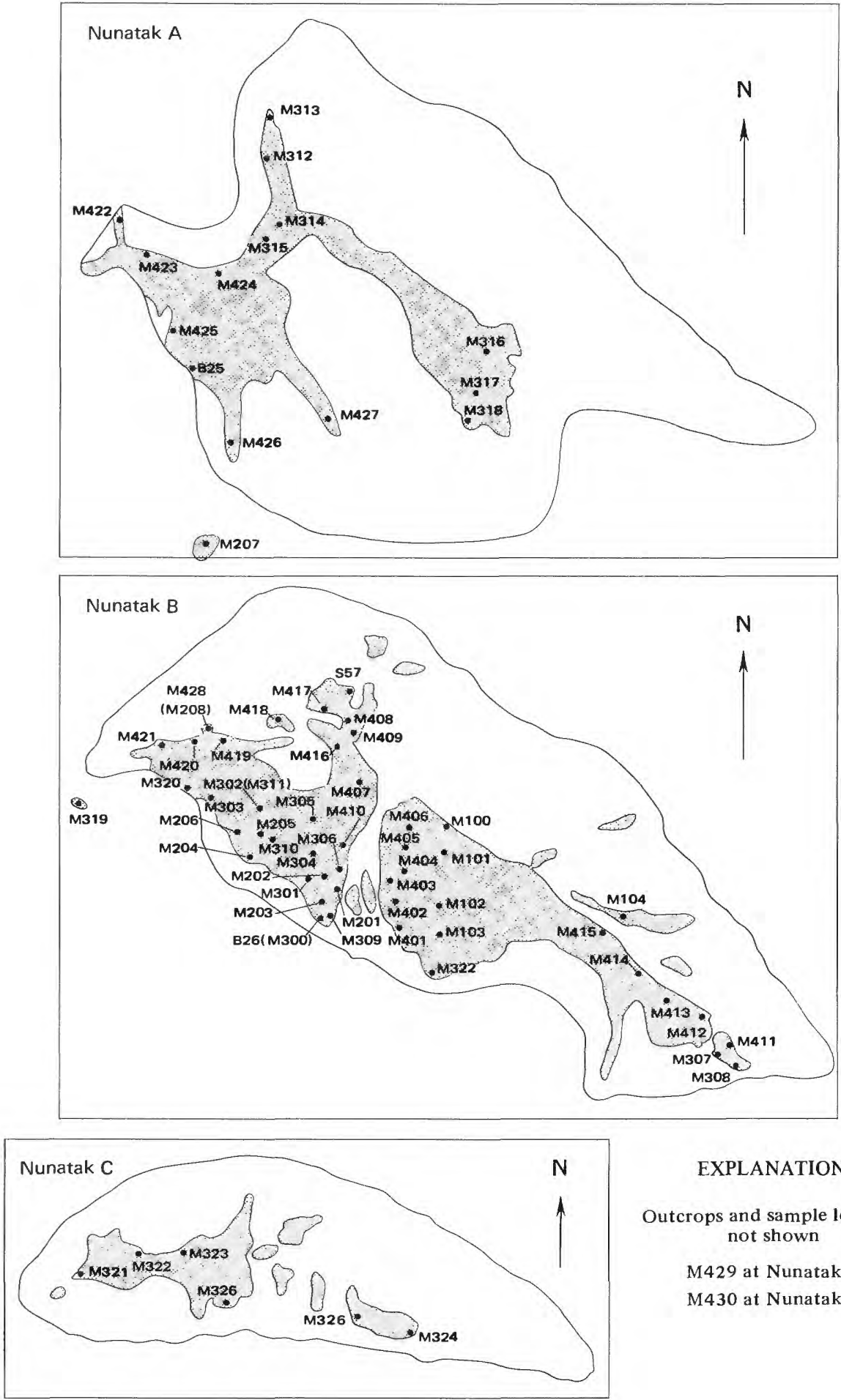

EXPLANATION

Outcrops and sample localities not shown

M429 at Nunatak D M430 at Nunatak E

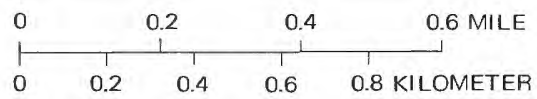

FiguRE 6.-Sample localities and outcrops (patterned) in the Copper Nunataks. 


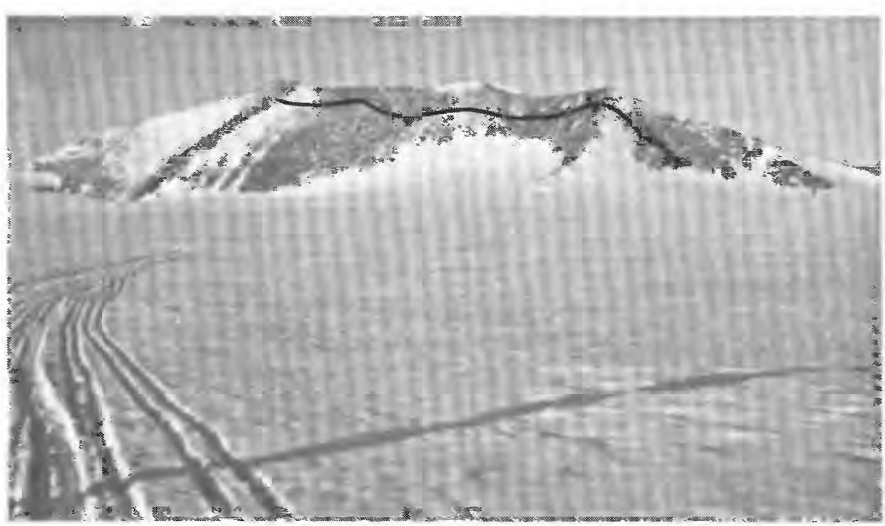

Figure 7.-Southwestern face of Nunatak B. Black curved line extending from one end of the nunatak to the other just below the crest is the dacite dike.

sharp, but some exhibit narrow gradational contacts with the enclosing igneous rock. Two thin sections (table 1) are of a hypidiomorphic-granular to allotriomorphic-granular hornblende diorite and hornblende syenodiorite; minerals are the same as those of the enclosing granodiorite, consisting mostly of abundant euhedral hornblende and uncommon biotite with interstitial plagioclase (calcic andesine), K-feldspar, and quartz.

\section{APLITE AND PEGMATITE DIKES}

Light pink, or less commonly white, aplite and pegmatite dikes are abundant (to 10 percent of rock volume in some areas) end-stage products of the intrusive activity that produced the medium-grained granodiorite (fig. 9). Most aplite dikes. are $2-15 \mathrm{~cm}$ wide, but several are more than $10 \mathrm{~m}$ wide. Coarse-grained ( $5 \mathrm{~mm}$ to $3 \mathrm{~cm}$ ) to very coarse grained pegmatite dikes are intimately associated with, and in some places gradational into, aplites; they have the same dimensions and attitudes as the aplite dikes but are significantly less abundant. The dominant strike of aplitepegmatite dikes is northwest; dips range from $40^{\circ}$ to vertical with no apparent preferred orientation. Two thin sections (table 1) have a typical fine-grained allotriomorphic-granular texture and consist chiefly of K-feldspar (rarely grid-twinned), quartz, and less abundant plagioclase; perthite and myrmekite are rare. The rocks are in the quartz monzonite and granite fields of the plagioclase, K-feldspar, and quartz diagram (fig. 5).

\section{DACITE DIKE}

A single thin (1-4 $\mathrm{m}$ wide) subvertical north-northeast- to west-northwest-striking, dark-green to black dike cuts the medium-grained granodiorite, associated aplites, and pegmatites at Nunatak B (figs. 4, 7). In most places it is a hornblende dacite, with finer grained chilled margins; at several places where it is thicker, the interior is a lamprophyre of small (1$3 \mathrm{~mm}$ ) hornblende phenocrysts in a fine-grained phaneritic matrix. Small pyrite crystals as much as $2 \mathrm{~mm}$ across are conspicuous in hand specimen.

Contained minerals ( 3 thin sections, table 1 ) are the same as those in the medium-grained granodiorite. The seriate or porphyritic rock consists mainly of euhedral green hornblende in a groundmass of mostly anhedral crystals of abundant plagioclase and hornblende. Minor K-feldspar, quartz, biotite, and opaque minerals are present (fig. 10). Ferromagnesian minerals are moderately to extensively altered to chlorite and epidote; anorthite content of plagioclase cannot be determined, owing to saussuritization. This alteration is probably deuteric, because the adjacent granodiorite wallrock is fresh. The ternary diagram (fig. 5) shows that the rocks fall in the dacite field and in the lower right part of the rhyodacite field. A single chemical analysis of a dacite dike is given in tables 2 and 3.

\section{COPPER NUNATAKS PLUTON}

The dominant rock type in the Copper Nunataks is that of the younger stock, which has an average composition of quartz monzonite and underlies an area of at least $40 \mathrm{~km}^{2}$. It is here named the Copper Nunataks pluton. It represents the first event in the younger igneous episode. Specimens are easily distinguishable from the older granodiorite by (1) lack of alteration, (2) considerably coarser grain size, and (3) light-gray or pinkish-gray color which, owing to the sparseness of ferromagnesian minerals and dark inclusions, is significantly lighter in color than the granodiorite pluton (fig. 11). In contrast to the older batholith, the Copper Nunataks pluton exhibits considerable internal variety in texture and composition. At Nunataks A, B, and C (fig. 3), the pluton is mostly granodiorite to quartz monzonite, at Nunatak $\mathrm{E}$ it is quartz monzonite, and at Nunatak D it is granite (figs. 12,13). Thus the pluton appears to be concentrically zoned from a more mafic marginal zone to a silicic interior at Nunatak D. A $\mathrm{K}$-Ar biotite date of $95.2+1.5 \mathrm{~m}$.y. was determined for the stock (specimen M430a) by A. H. Clark, Edward Farrar, and S. L. McBride (written commun., 1974).

Sharp intrusive contacts are exposed at Nunataks B and $\mathrm{C}$; here the older granodiorite body and the dacite dike are sheared and slightly altered in the area from the contact to a distance of several centimeters. The Copper Nunataks pluton is somewhat finer grained at the margin than elsewhere in the body. At one location along the contact at Nunatak B, the rock is gneissic for a width of several meters. The light-gray, mediumgrained gneissic bands, $5-50 \mathrm{~cm}$ wide, vary in quartz and feldspar content, grain size, and amount of fer- 
romagnesian minerals; the rock in different bands varies from quartz diorite to granodiorite. The foliation is considered to be primary, strikes parallel to the contact, and dips east under the older rock.

The Copper Nunataks pluton occurs as resistant, massive outcrops that in places have a slightly crumbly weathered surface. Microscopic study of 17 thin sections (table 1) shows that different sizes (as much as $3 \mathrm{~cm}$ long) and shapes (anhedral, less commonly subhedral) of pink or gray $\mathrm{K}$-feldspar crystals result in different textures that are most commonly porphyritic but may be equigranular (hypidiomorphic-granular), poikilitic, or seriate (fig. 14); the three latter textures appear to predominate in the interior (Nunataks D and E). K-feldspar is rarely grid-twinned and perthite is scarce to absent. Plagioclase, hornblende, and biotite are subhedral and quartz is anhedral; these minerals average $2-3 \mathrm{~mm}$ in size and few exceed $1 \mathrm{~cm}$. Most plagioclase crystals are zoned and have an anorthite content that is slightly lower than that of the granodiorite pluton: most zoned crystals range from calcic andesine cores to calcic oligoclase rims; most unzoned crystals range from sodic to intermediate andesine. Rare amounts of myrmekite occupy small areas near the boundaries of plagioclase and K-feldspar or plagioclase and quartz. Quartz has undulatory extinction, and in some places it exhibits either sutured boundaries or mortar texture suggestive of late-stage plutonic movement. Green hornblende and brown biotite have the same pleochroic formulas as those in the granodiorite pluton. The hornblende content varies considerably whereas the content of biotite is more uniform. Most biotite is slightly altered to chlorite (penninite?) along cleavages and is much less commony altered to epidote. Opaque minerals are abundant and most are magnetite; pyrite is virtually absent. Sphene is abundant and occurs as large, conspicuous euhedral crystals as much as several millimeters long; apatite is relatively abundant, but zircon and other nonopaque accessory minerals are rare.

On the ternary diagram (fig. 5), the rocks of the Copper Nunataks pluton occupy an elongate belt spanning the quartz monzonite field extending from just inside the granodiorite field to the edge of the granite field. Specimens collected close to the contacts are more mafic and contain more biotite, hornblende, and sphene, and have a higher hornblende-to-biotite ratio (table 1) than those collected farther inward from the contact. In comparison with rocks of the granodiorite batholith, the rocks of the Copper Nunataks pluton are characterized by a higher content of K-feldspar, opaque minerals, and sphene; a higher hornblende-tobiotite ratio; and a lower content of plagioclase, quartz, hornblende, and biotite.
Rapid rock chemical analyses and semiquantitative spectrographic analyses of fresh samples collected from the Copper Nunataks pluton (tables 2 and 3 ) show a systematic increase inward towards Nunatak D in $\mathrm{SiO}_{2}, \mathrm{~K}_{2} \mathrm{O}, \mathrm{Sr}, \mathrm{V}, \mathrm{Ga}, \mathrm{Ce}, \mathrm{Y}, \mathrm{Cr}, \mathrm{Co}, \mathrm{Yb}$ and a systematic decrease in $\mathrm{Al}_{2} \mathrm{O}_{3}, \mathrm{Fe}_{2} \mathrm{O}_{3}, \mathrm{FeO}, \mathrm{MgO}, \mathrm{CaO}, \mathrm{TiO}_{2}$, $\mathrm{P}_{2} \mathrm{O}_{5}, \mathrm{MnO}$, and perhaps $\mathrm{Pb}$. Proceeding inward from the contacts, sample M315a is comparable to Nockolds' hornblende-biotite granodiorite; M321i is somewhat higher in $\mathrm{CaO}$ and lower in $\mathrm{K}_{2} \mathrm{O}$ than Nockolds' average granodiorite; M421 is somewhat higher in $\mathrm{CaO}$ than Nockolds' average hornblende-biotite adamellite; M318a and M430 are somewhat higher in CaO than Nockolds' average adamellite; and M429c is somewhat higher in $\mathrm{CaO}$ and lower in $\mathrm{Na} 2 \mathrm{O}$ and $\mathrm{K}_{2} \mathrm{O}$ than Nockolds' calc-alkali granite. Specimen B25a is from assimilated material near a stope block and is somewhat higher in $\mathrm{CaO}$ and lower in $\mathrm{K}_{2} \mathrm{O}$ than Nockolds' average granodiorite.

Dark inclusions in the Copper Nunataks pluton are much less abundant (about 1 per $\mathrm{m}^{2}$ of rock area), lighter colored, and smaller (average diameter about $2 \mathrm{~cm}$ and maximum length about $10 \mathrm{~cm}$ ) than those in the medium-grained granodiorite. The abundance of inclusions increases slightly toward the intrusive contact. The included rock is a syenodiorite (table 1 ) with both porphyritic texture (subhedral to euhedral plagioclase and green hornblende phenocrysts as much as $5 \mathrm{~mm}$ long) and poikilitic texture (sparse K-feldspar as much as $3 \mathrm{~mm}$ ) in a fine-grained (about $0.4 \mathrm{~mm}$ ) matrix of subhedral plagioclase, hornblende, and opaque minerals and of anhedral quartz. Anorthite content of twinned, zoned plagioclase phenocrysts ranges from calcic oligoclase to calcic andesine; anhedral, slightly zoned groundmass plagioclase is mostly sodic to intermediate andesine. The contrast in relative amounts of minerals between the Copper Nunataks and granodiorite plutons is paralleled by those in their contained inclusions; inclusions in the Copper Nunataks pluton contain less hornblende and more K-feldspar, quartz, opaque minerals, and sphene than inclusions in the granodiorite pluton.

Intrusion of the Copper Nunataks pluton was largely passive. Large-scale stoping and partial assimilation of the rock of the older granodiorite is apparent at many locations at Nunatak A (fig. 15). Some stoped blocks, as much as $8 \mathrm{~m}$ in diameter, have sharp contacts with quartz monzonite of the Copper Nunataks pluton; more commonly, however, contacts are gradational over several tens of meters, and the rock in these zones is compositionally and texturally transitional between that of the two plutonic rock types. Microscopic study of seven specimens of the assimilated stoped blocks (table 1 ) indicates that most of those rocks were derived from 


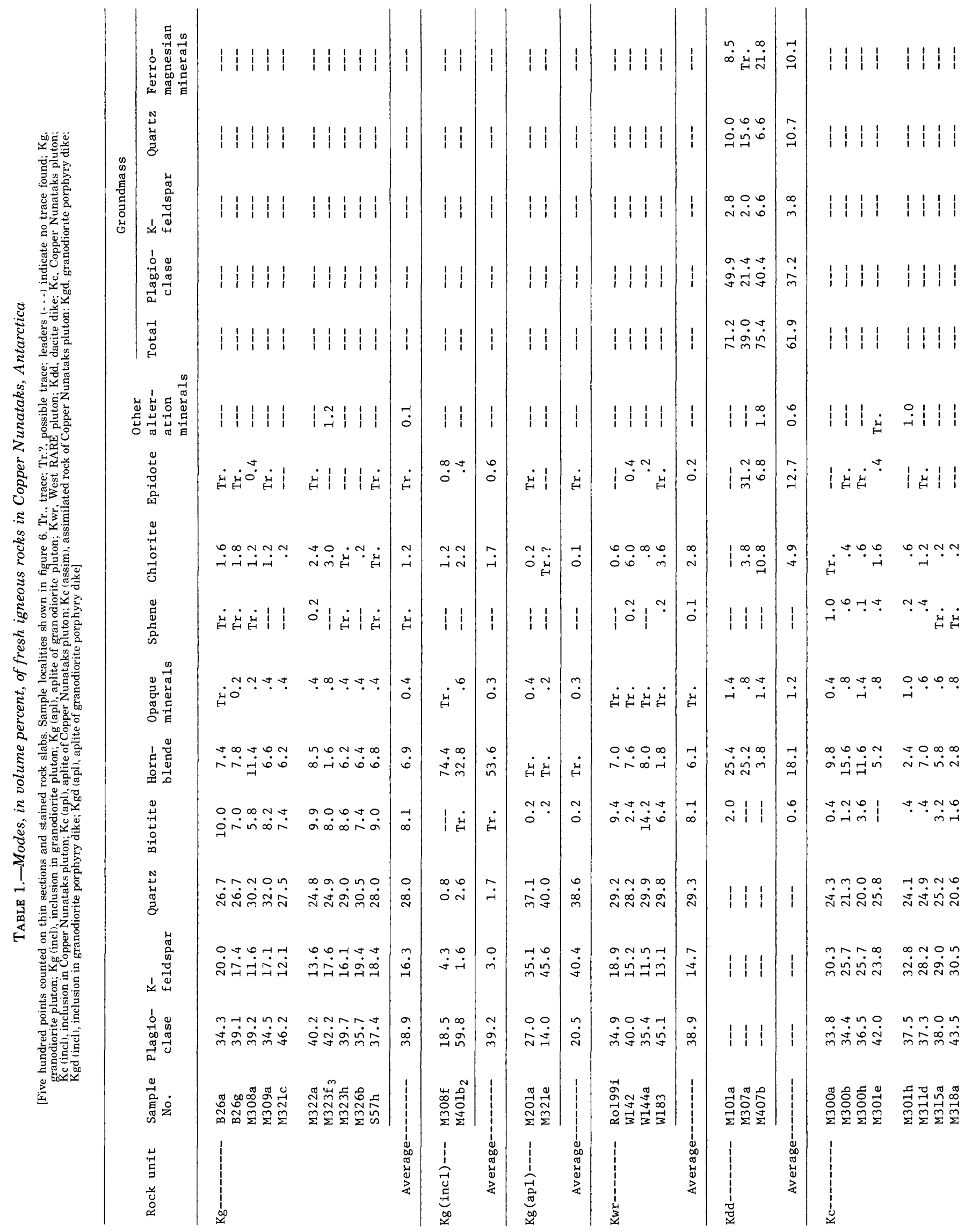




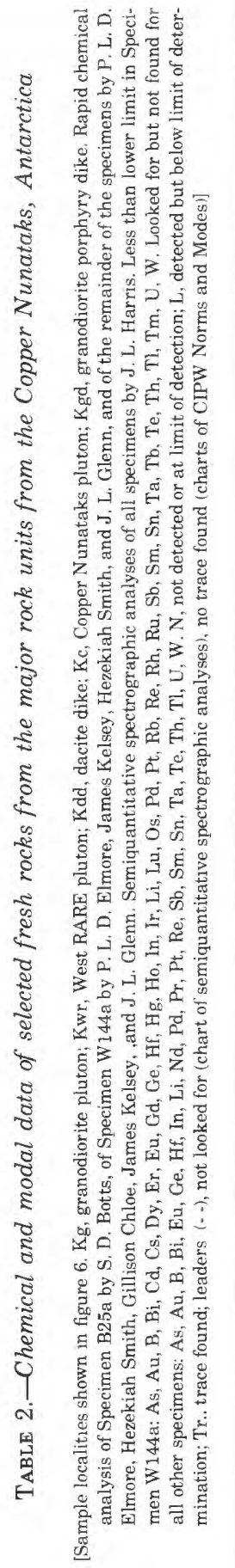

ت.

$\mid \begin{gathered}\text { กี } \\ \text { ก } \\ \infty\end{gathered}$

올

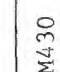

誉

$\underset{\substack{10 \\ \infty}}{m}$

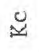

口

(3)

ت্

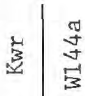

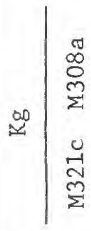

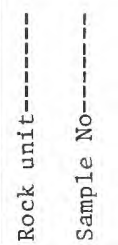

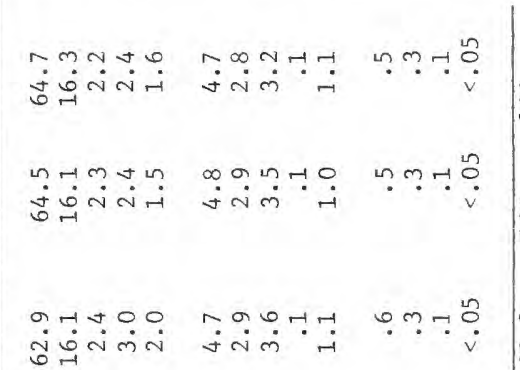

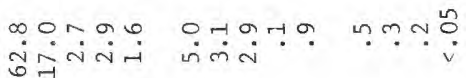

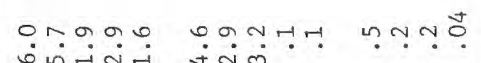

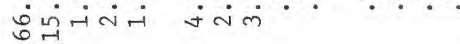

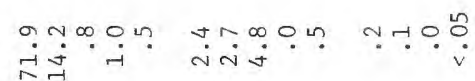

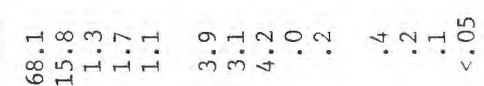

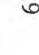

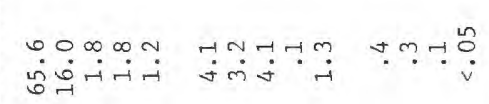$$
\text { (1) }
$$

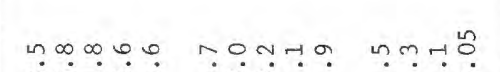

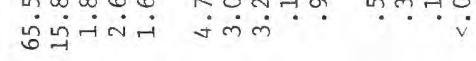

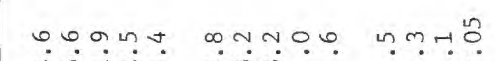

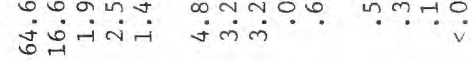

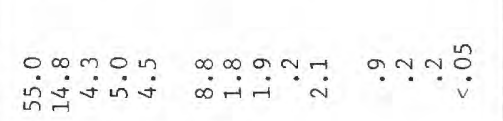

in

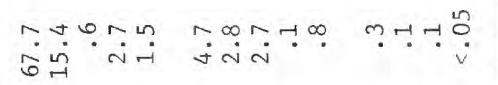

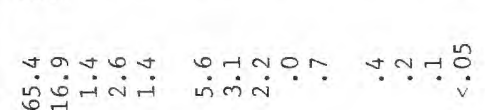

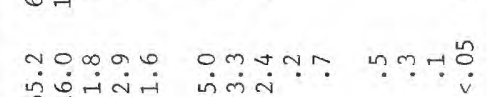

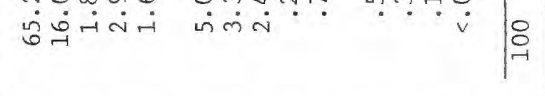

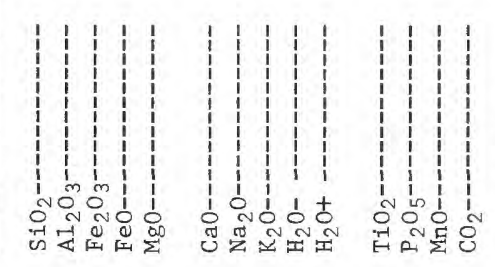

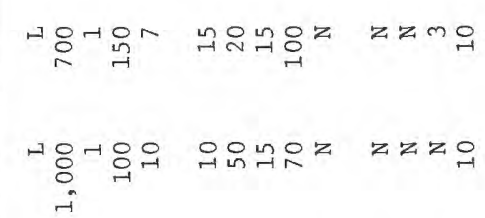

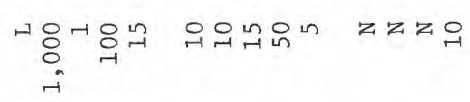

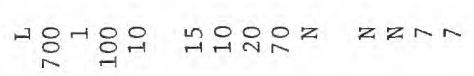

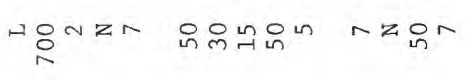

율 mnoㅁ zzzm

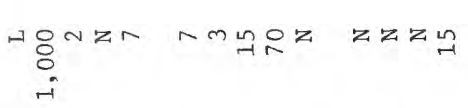

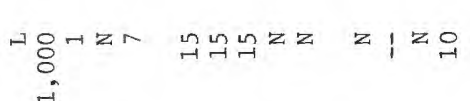

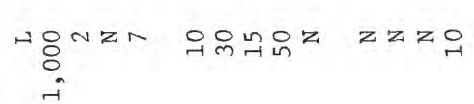

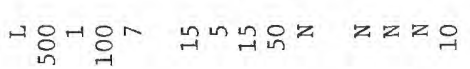

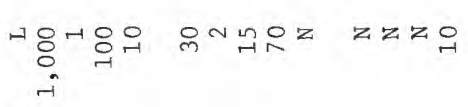

뮴유 윰z zing

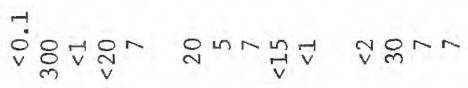

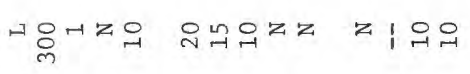

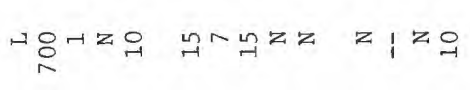

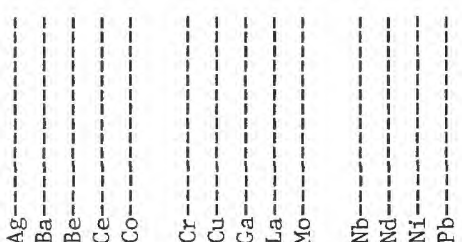




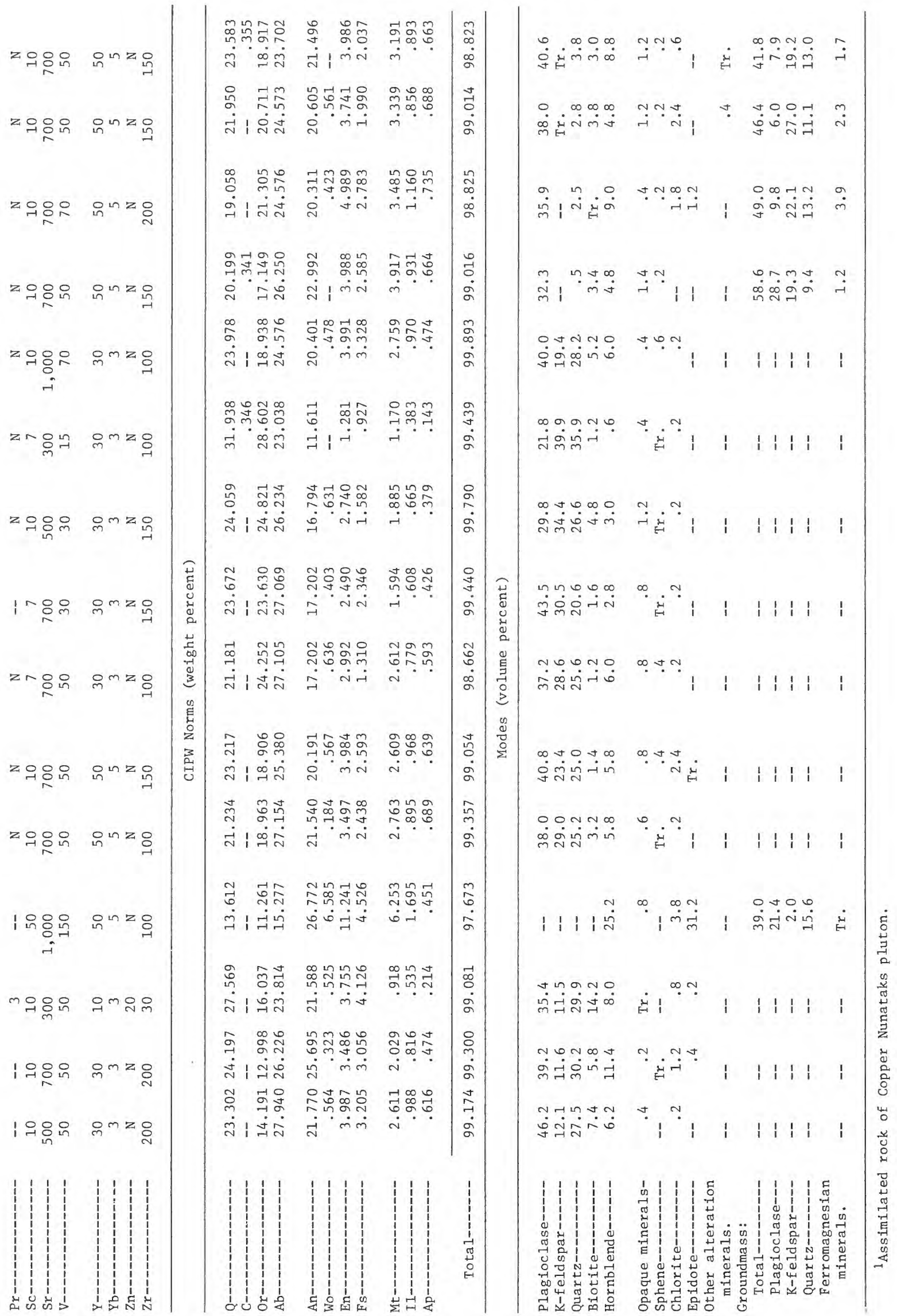




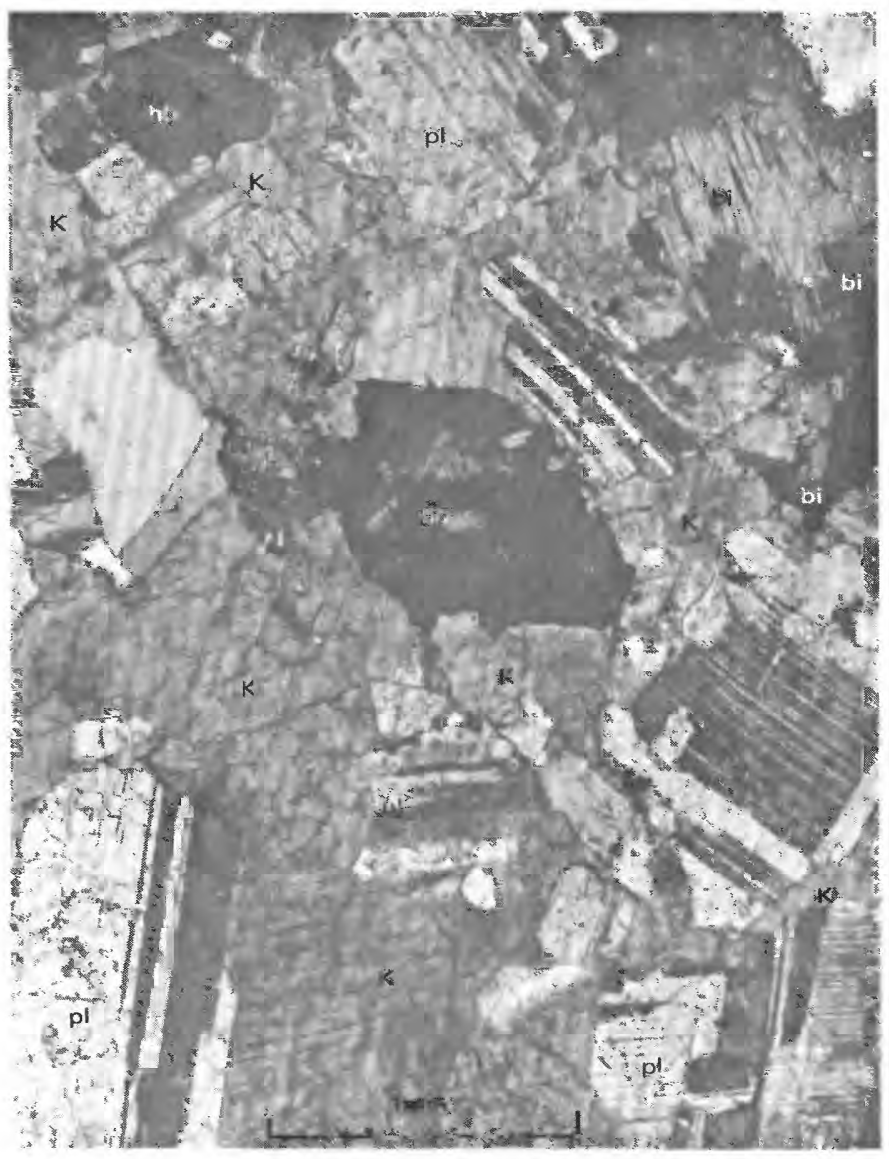

FIGURE 8.-Mostly fresh rock of the granodiorite pluton: small anhedral crystals of quartz (Q) and small subhedral crystals of plagioclase ( $\mathrm{pl}$ ), hornblende ( $\mathrm{hb}$ ), and biotite (bi) poikilitically enclosed in a large crystal of untwinned K-feldspar (K). Specimen M309a. Crossed polars.

a contaminated quartz monzonite melt that was perhaps a border phase of the Copper Nunataks pluton. The rock is medium-grained hypidiomorphic-granular or hypidiomorphic-seriate. Some rocks have a bimodal grain size containing small, commonly-altered crystals similar to those of the older granodiorite, and larger fresh crystals derived from the quartz monzonite melt. Partly assimilated stoped blocks exhibit strongly undulose quartz with sutured boundaries or mortar texture; some crystals are bent and broken. One sample is allotriomorphic-granular. Most assimilated rocks plot between the fields of the granodiorite and Copper Nunataks plutons on the triangular diagram (fig. 5).

\section{APLITE AND PEGMATITE DIKES}

Gray or pink aplite dikes and associated pegmatite dikes are volumetrically abundant end-stage products of the Copper Nunataks pluton intrusive episode (figs. $9,15)$; they are especially abundant near the pluton contacts where they may make up 10 or 20 percent of

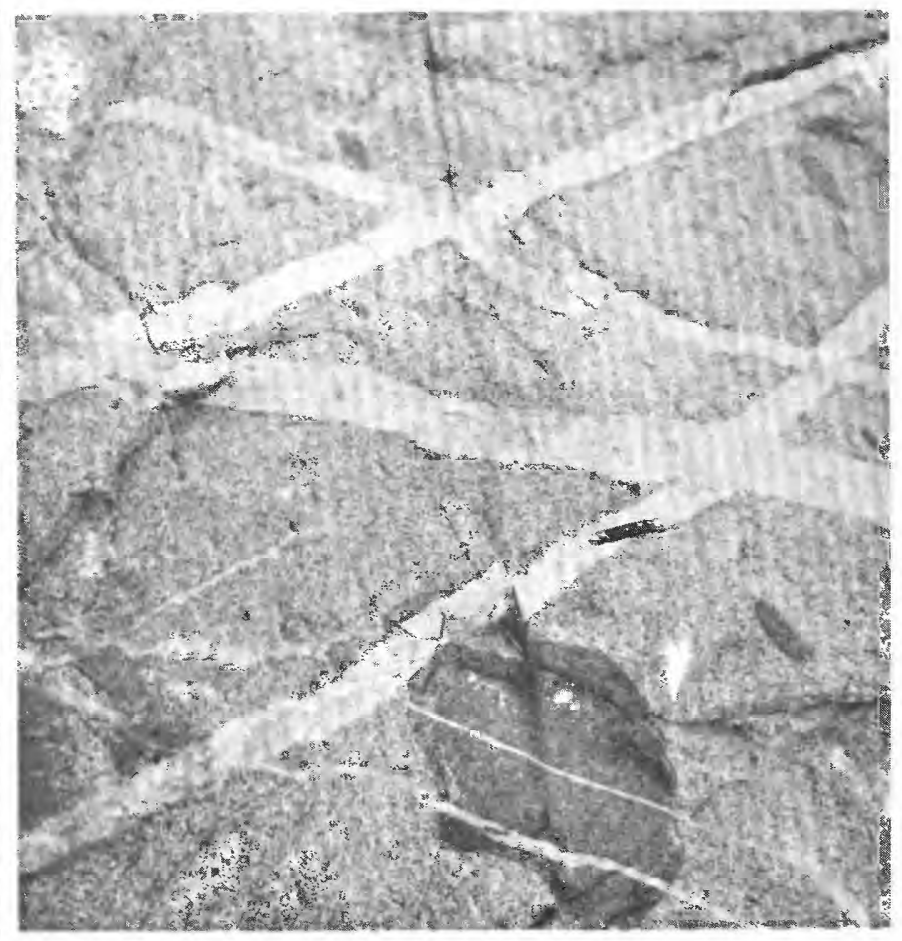

FIGURE 9.-Aplite dikes of several ages in granodiorite pluton near the Copper Nunataks pluton intrusive contact, outcrop M201, Nunatak B. Pocketknife lies on an older aplite dike that is intruded into its parent granodiorite and a mafic inclusion (black) in the granodiorite. This aplite dike and the inclusion are offset by a thin gray shear fracture. Several younger aplite dikes, of the Copper Nunataks pluton episode, cut the gray shear fracture. Note offset of the older aplite dike by the fracture occupied by one of the younger aplite dikes, just above and to the right of the knife.

the rock. Pegmatite bodies may occur with aplitic material or as separate masses; they are significantly more abundant than the pegmatites of the granodiorite pluton. Most pegmatite or aplite dikes are a few centimeters to $25 \mathrm{~cm}$ wide, but some are more than $10 \mathrm{~m}$ wide. Crosscutting relations indicate at least two events of aplite-pegmatite intrusion. One event produced an older subhorizontal to gently dipping, nonrooted series of pod-form masses and dikes and the second, a younger one, produced a steeply dipping set, rooted to deeper parts of the pluton. Crosscutting relations also are exhibited within the younger dike set. The steeply dipping dikes have numerous trends. Small masses of tourmaline and garnet occur within some pegmatites. Seven thin sections show that, with the exception of one microgranite, most rocks are typical aplites (table 1). Grid-twinned K-feldspar and perthite are rare. Most aplites are classified as granites (fig. 5); paralleling the differences between the two plutonic rock types, the aplites of the Copper Nunataks stock contain less quartz than those of the granodiorite batholith. 


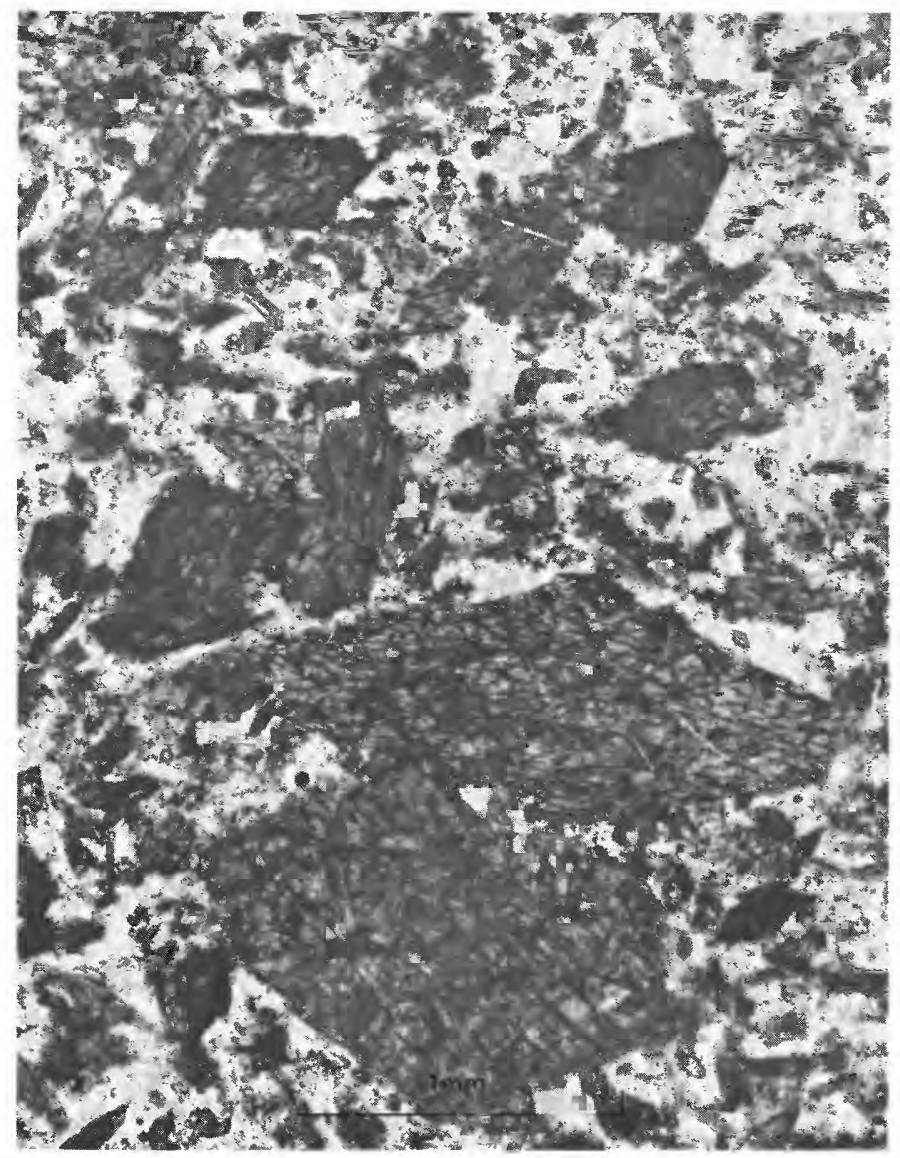

FIGURE 10.-Fresh dacite dike: a lamprophyric texture of subhedral to euhedral hornblende crystals of all sizes in a fine-grained groundmass of anhedral feldspar and lesser quartz, hornblende, biotite, and opaque minerals. Specimen M101. Plane light.

\section{GRANODIORITE PORPHYRY DIKES}

The youngest igneous rock in the area is granodiorite porphyry exposed in distinctive dikes. Two of these are as narrow as $1 \mathrm{~m}$, but most are 5-20 m wide; all are subvertical and strike from north-northwest to westnorthwest. The four smallest dikes are at Nunataks A and $\mathrm{C}$, but the largest and best exposed are at Nunatak $\mathrm{B}$ (fig. 4). A K-Ar biotite determination of $95.6 \pm 1.5$ m.y. (specimen M311a) by Clark, Farrar, and McBride (written commun., 1974) suggests that the dikes are related to the igneous activity of the Copper Nunataks pluton.

All dikes have medium-gray to black chilled margins that are as much as several meters thick. The country rock is sheared and slightly to moderately altered for several centimeters outward from the intrusive contacts, and the chilled margins also commonly show similar shearing and deuteric(?) alteration. Thin coatings or disseminated crystals of epidote occur locally in the chilled rock and at the contacts in the country rocks. The chilled margins are aphanitic, with rare

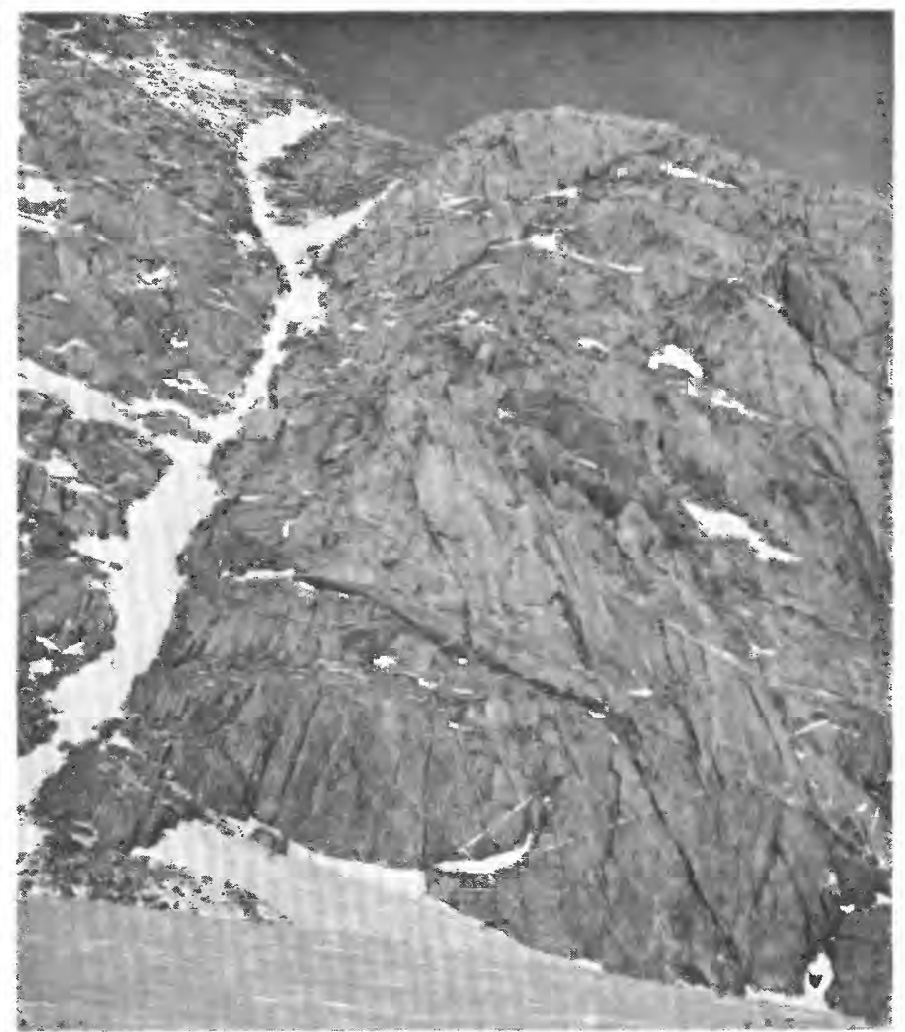

FIGURE 11.-Typical outcrop of Copper Nunataks pluton, outcrop M425, Nunatak A. Snow-filled ravine on left about $3 \mathrm{~m}$ wide at base of nunatak.

phenocrysts; inward, phenocryst abundance and size of both phenocrysts and groundmass increase; the dike interiors are light gray. The transition is most commonly gradational, but in several places it is sharp across less than a 5 -mm width, indicating a younger pulse of more crystal-rich rock.

The rock is fresh in most places. However, the 5-8 m wide dike at Nunatak A is entirely altered to saussurite and chlorite; altered rock does not continue for more than 1 or $2 \mathrm{~m}$ into the country rock. This alteration is most probably caused by deuteric or hydrothermal solutions very closely tied in time and origin to dike intrusion. Petrography, clay mineralogy (table 4), and the results of semiquantitative spectrographic analyses (table 3 ) show that the altered rock is similar to hydrothermally altered argillic rock of the copper deposit. This similarity, and the presence of disseminated sulfides in some chilled dike margins, adds support to our belief that the main period of copper mineralization is related to and shortly followed emplacement of granodiorite porphyry dikes.

Modes of 17 thin sections are presented in table 1 , and four chemical analyses are given in tables 2 and 3 . Minerals are identical to those of previously described rocks, but their size, shape, and relative abundances 


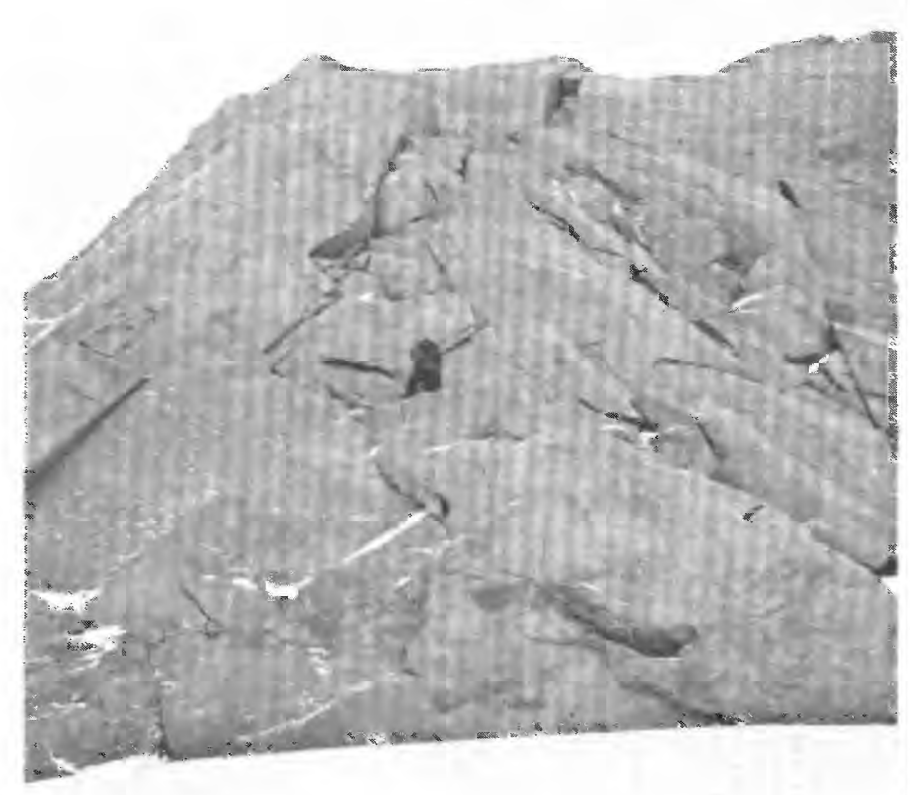

Figure 12.-Typical outcrop of massive Copper Nunataks pluton. Nunatak D. Rock is a fresh coarse-grained granite in presumed interior of pluton; note lack of aplite-pegmatite dikes and mafic inclusions.

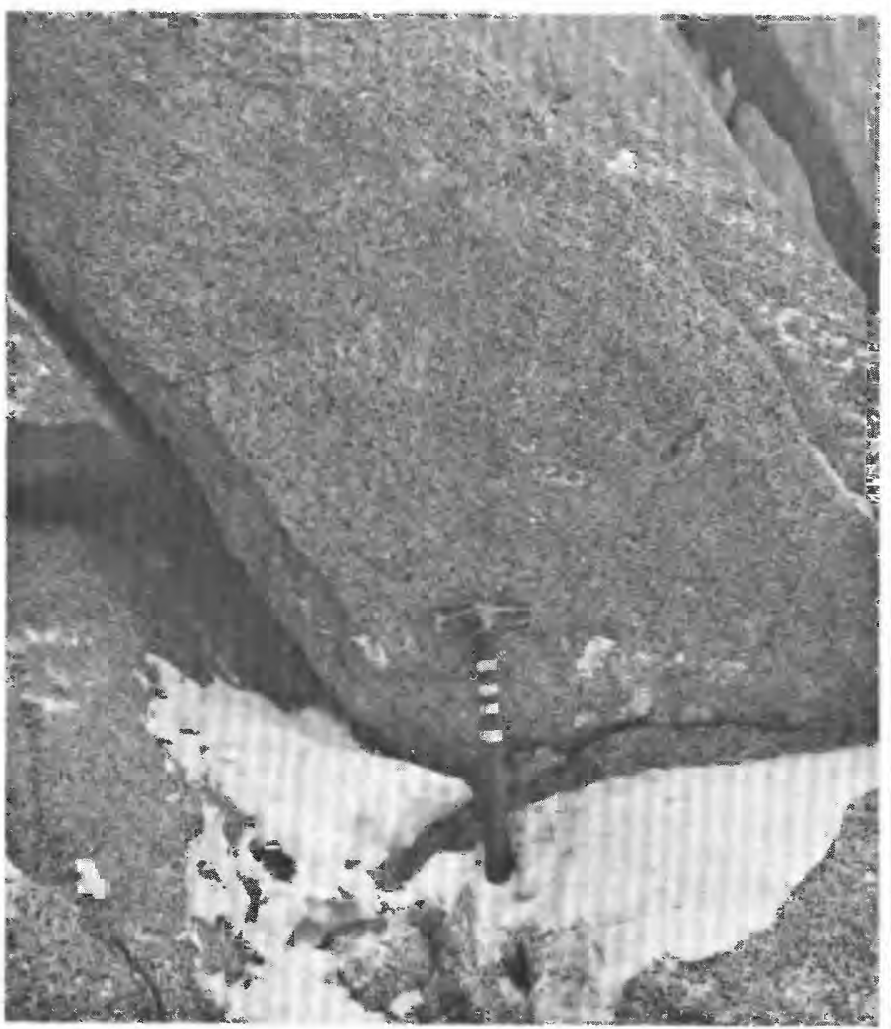

FiguRE 13.-Fresh coarse-grained granite in presumed interior of Copper Nunataks pluton, Nunatak D. Granite contains 0.5$1.5 \mathrm{~mm}$ biotite books and hornblende crystals as well as abundant smoky quartz. are different. The most common phenocryst is euhedral and subhedral plagioclase; the phenocrysts average 2 or $3 \mathrm{~mm}$ in length with a maximum of more than $7 \mathrm{~mm}$; less abundant euhedral hornblende crystals average 1 or $2 \mathrm{~mm}$ in length with a maximum of $1 \mathrm{~cm}$, and euhedral or subhedral biotite grains average $1 \mathrm{~mm}$ in length with a maximum of $4 \mathrm{~mm}$. Deeply embayed "beta" quartz as much as $3 \mathrm{~mm}$ across and untwinned $\mathrm{K}$-feldspar as much as 1 or $2 \mathrm{~mm}$ long, as well as small crystals of opaque minerals, are present but uncommon. The groundmass consists of tiny anhedral crystals that are less than $0.1 \mathrm{~mm}$ at the chilled margins of the dikes (fig. 16) and commonly reach $0.2-0.3 \mathrm{~mm}$ in the interior; the interiors of the larger dikes contain a micrographic groundmass texture (granophyric) and the crystals have myrmekitic to cuneiform intergrowths up to $0.6 \mathrm{~mm}$ across (fig. 17). The main groundmass minerals are K-feldspar (no gridtwinning) and less abundant quartz; plagioclase, hornblende, biotite, and opaque minerals are generally minor. Most plagioclase phenocrysts are zoned; their anorthite content generally ranges between intermediate labradorite cores and sodic andesine rims. Hornblende and biotite have the same pleochroic formulas as those in the plutonic rocks. The hornblende content has a relatively wide range. Pyrite and magnetite are moderately abundant. Sphene is uncommon as small anhedral to subhedral crystals.

Phenocryst and groundmass contents of plagioclase, hornblende, and opaque minerals are generally greater in the granodiorite dikes than in the Copper Nunataks pluton, but K-feldspar, quartz, biotite, and sphene are less abundant (table 1). The granodiorite porphyry dike rock occupies a linear belt on the modal ternary diagram (fig. 5); this belt extends across the quartz monzonite field to a low-quartz position in the granodiorite field. The belt is parallel to, and displaced below and slightly to the left of, the field for the Copper Nunataks pluton. The rather wide compositional scatter within the belt largely reflects the relatively lower precision in point counting the fine-grained groundmass; generally the best modal data are those from coarser rocks of the interior of the dikes, and these lie toward the upper left part of the belt.

Rather inconspicuous, medium-gray fine-grained inclusions as much as $10 \mathrm{~cm}$ long rarely are present in the granodiorite dikes. A thin section of one specimen (table 1) shows a hypidiomorphic-seriate rock with grain size averaging $0.4 \mathrm{~mm}$ and a maximum of $1.5 \mathrm{~mm}$. The minerals are the same as those in the other igneous rocks and the other inclusions; the pleochroic formulas of hornblende and biotite are also the same. The larger crystals are plagioclase and hornblende. K-feldspar exhibits no grid-twinning. The 


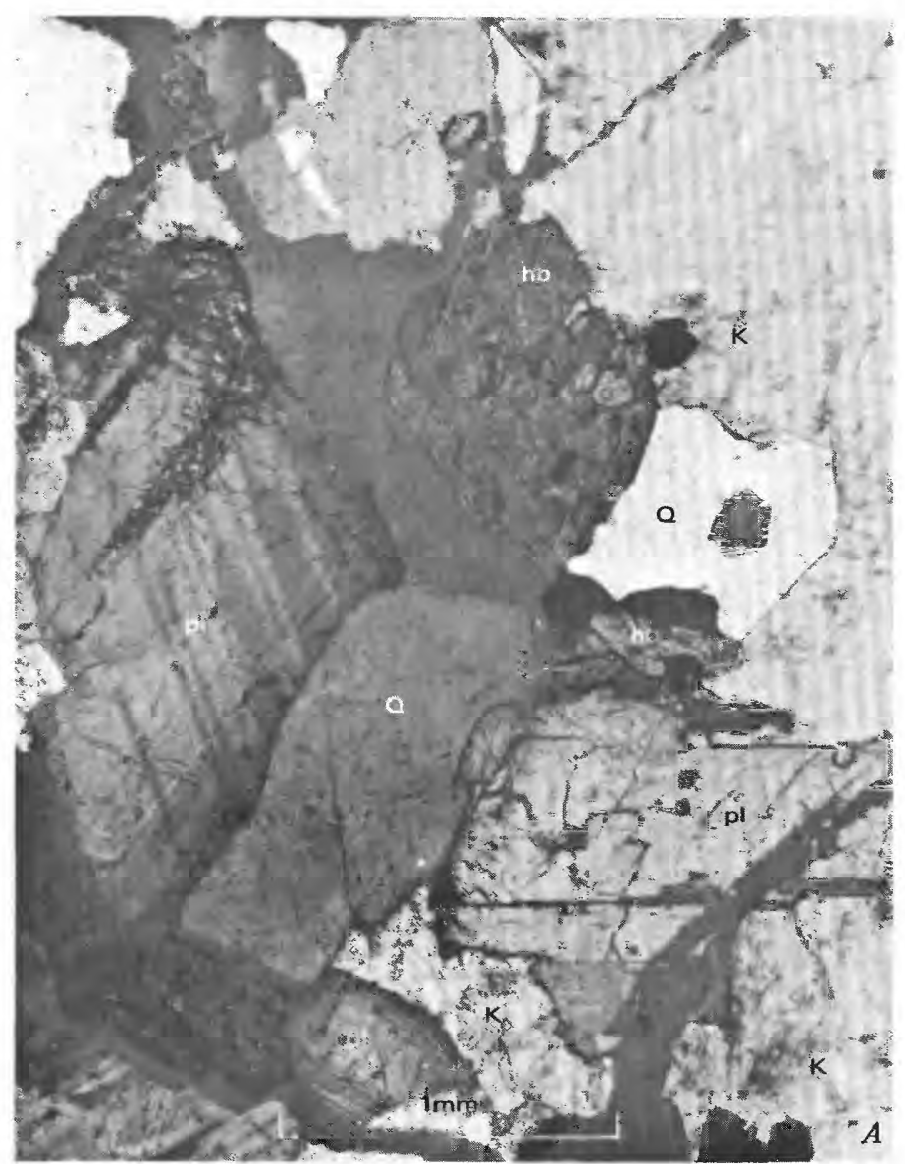

Figure 14.-Rocks of the Copper Nunataks pluton.

$A$, Fresh rock: Medium- to coarse-grained hypidiomorphic granular texture of K-feldspar (K), plagioclase (pl), quartz (Q), hornblende $(\mathrm{hb}$ ), and minor opaque minerals and sphene (sp). Specimen M311d, Nunatak B. Crossed polars.

commonly zoned plagioclase crystals are generally carlsbad twinned or untwinned; anorthite content of zoned crystals ranges from sodic andesine to sodic labradorite. The rock is modally classified in the low quartz and high plagioclase part of the quartz monzonite field, but it is more silicic than inclusions from the Copper Nunataks pluton.

\section{INTERPRETATION OF THE CHEMICAL AND MODAL DATA}

The major oxides are shown on a silica variation diagram (fig. 18). Plotted against increasing silica, the oxides of the combined igneous units exhibit a regular trend that is typical of the calc-alkaline rock series. Average alkali-lime index (Peacock, 1931) is slightly greater than 62 . Ternary diagrams of selected chemical constituents (fig. 19) also show trends characteristic of the calc-alkaline rock series. The data points of the combined igneous rocks define an overall systematic trend on the variation diagram and the ternary plots; the smoothness of the overall curve further sup-

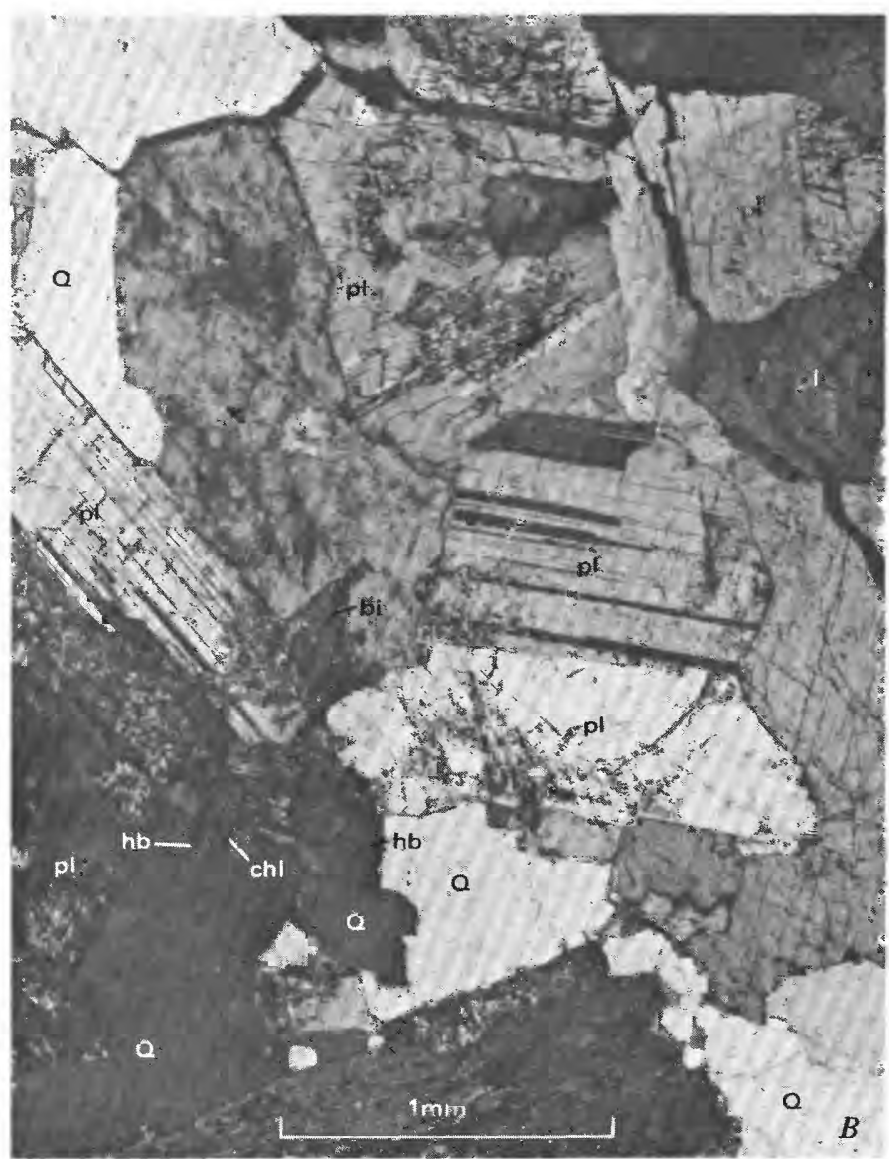

$B$, Mostly fresh rock: Medium-grained hypidiomorphic-granular texture of untwinned K-feldspar $(\mathrm{K})$, plagioclase $(\mathrm{pl})$, quartz $(\mathrm{Q})$, hornblende (hb), chlorite (chl), and biotite (bi). Feldspar is slightly sericitized and some biotite is altered to chlorite. Specimen M430, Nunatak E. Crossed polars.

ports the proposal that all rocks are genetically related to a single magma series.

Each igneous rock unit occupies a distinct and generally separate position on the various modal and chemical diagrams. The data points for individual rock units may form a tight cluster or a broad belt. Rocks of the Copper Nunataks stock occupy the longest belt; samples obtained nearer the intrusive contacts of this pluton lie progressively closer in all diagrams to the mafic end of the overall field, as defined by the granodiorite porphyry dike rocks. The consistent trends for this pluton are interpreted as formation by igneous differentiation of a single magma body. Another smaller belt of data points is defined by rocks of the medium-grained granodiorite pluton and rocks of the presumably equivalent West RARE pluton; these data, too, are interpreted to reflect differentiation of a single magma. Assimilated rock occupies a position between the fields of the granodiorite pluton and Copper Nunataks pluton. Mafic dike rocks are 


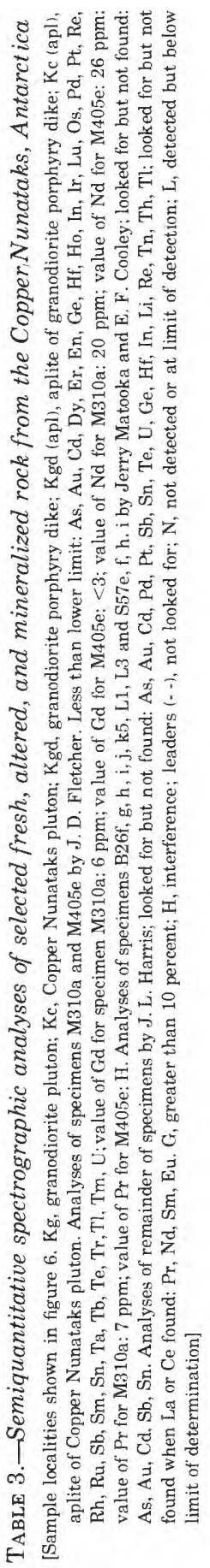

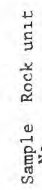

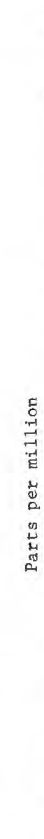

D.

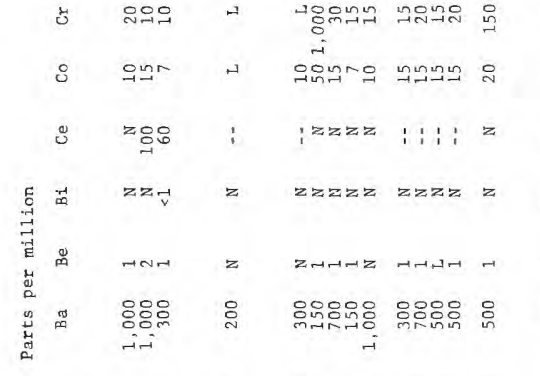

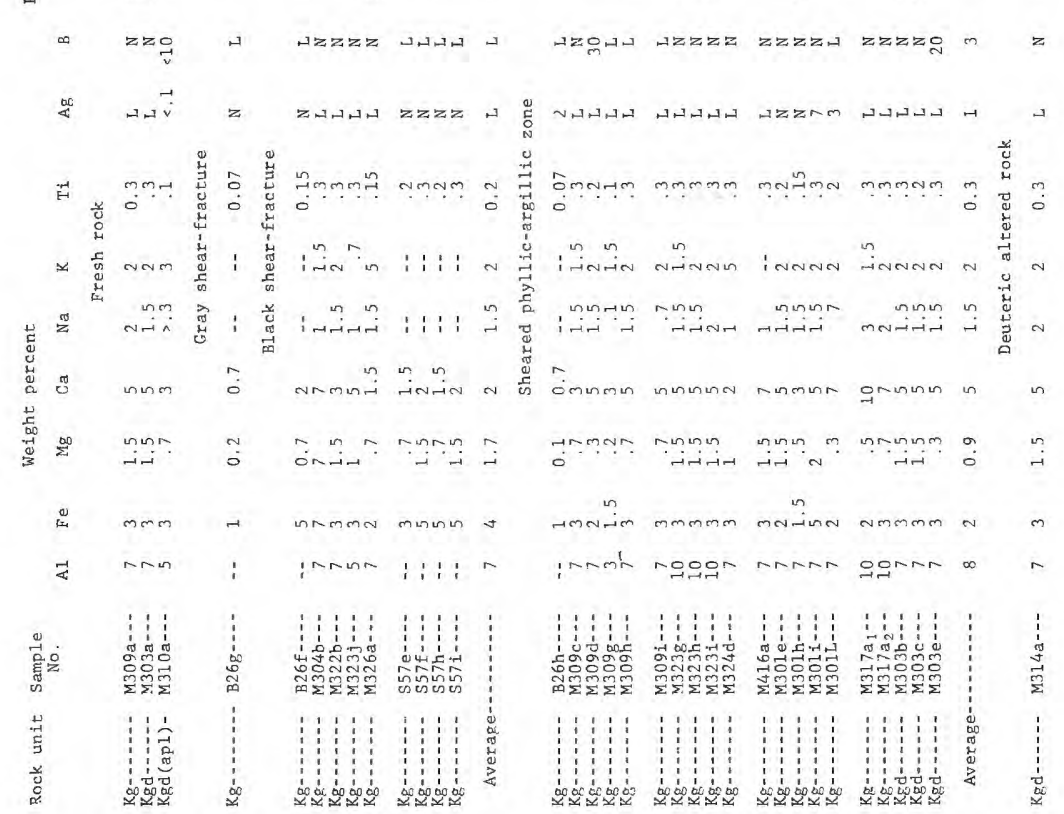




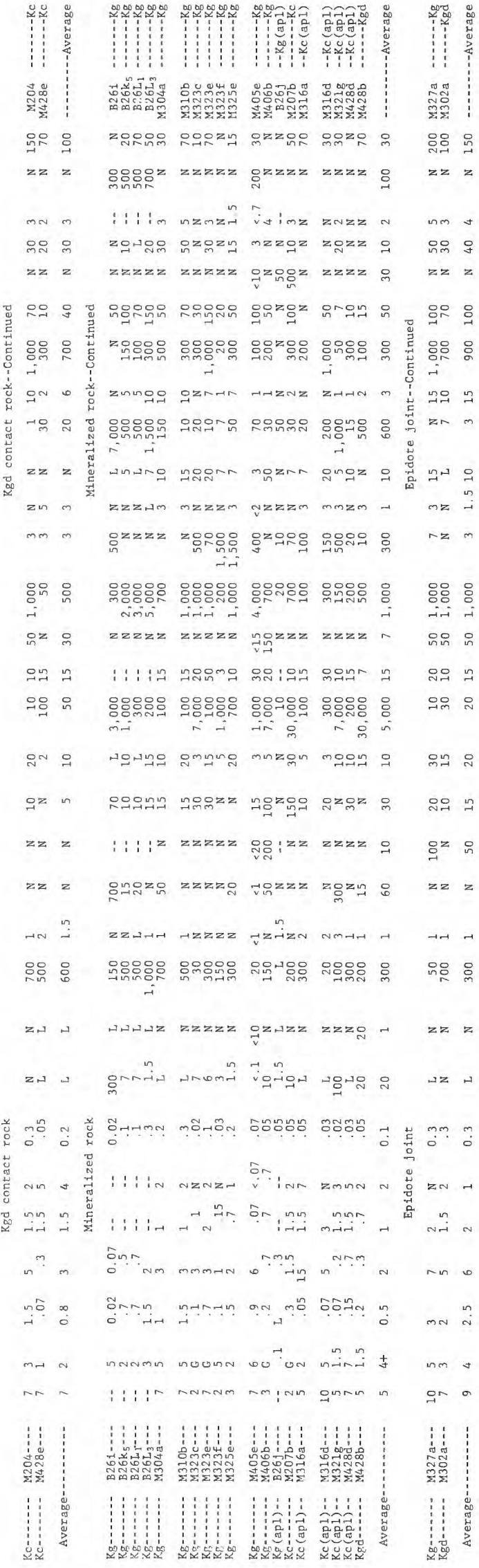

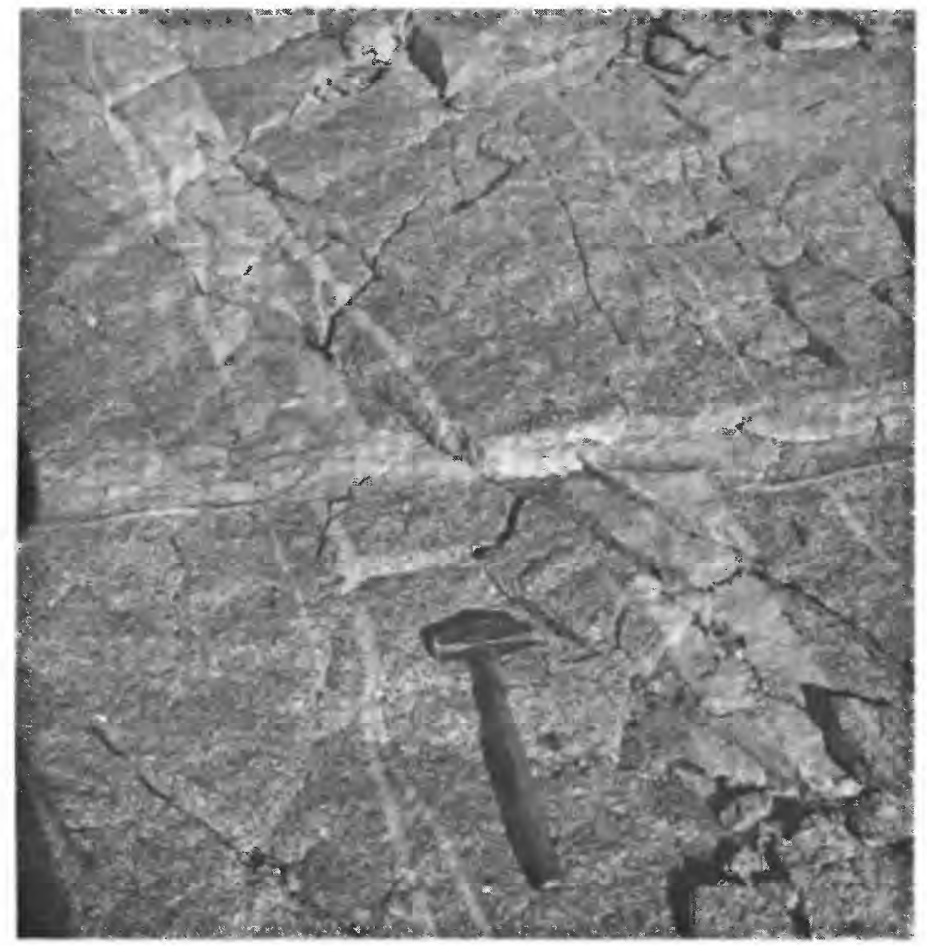

FigURE 15.-N. $80^{\circ} \mathrm{W}$. aplite dike offset along a fracture occupied by a younger N. $20^{\circ} \mathrm{E}$. aplite dike, outcrop M424, Nunatak A. Country rock is a large stoped block in the granodiorite pluton, not far from the contact with the enclosing Copper Nunataks pluton. Affiliation of the aplite dikes is unknown.

more tightly grouped on the diagrams although at least the spread of modal data on the granodiorite porphyry dikes suggest that magma of these dikes may have differentiated internally prior to or during intrusion.

Despite its general smoothness, the overall curve on most diagrams (figs. $5,18,19$ ) may be separated into two parallel belts of data points. The makeup of the belts is consistent with the interpretation for two similar Upper Cretaceous igneous-structural episodes in the area of the Copper Nunataks. The first belt is defined largely by samples from the granodiorite pluton and the presumed correlative West RARE pluton; the data points of the slightly younger aplite-pegmatite dikes and the dacite dike define the opposite ends of this belt. The second belt is defined largely by samples from the Copper Nunataks pluton; the data points of the slightly younger aplite-pegmatite dikes and granodiorite porphyry dikes define the opposite ends of it. The axes of the first and second belts are emphasized on each diagram by a dashed and a solid line respectively; these lines are referred to as the granodiorite pluton trend line and Copper Nunataks pluton trend line. Each smooth trend line presumably represents a common magma chamber tapped at only slightly different times: the granodiorite pluton and associated dikes represent tapping at only slightly different times 
of different levels of one common magma chamber; the Copper Nunataks pluton and associated dikes represent tapping at only slightly different times of different levels of a second, younger common magma chamber. Most dike material intruded along the regional extension joint direction (see section on "Trends of Systematic Joints").

Each of the two magmatic episodes displayed the same sequence of plutonism, related late-stage aplitepegmatite dike intrusion, and emplacement of relatively mafic dikes. Both the dacite dike and the granodiorite porphyry dikes show similar chemical trends away from their respectively older pluton. Both dikes are higher than their parent pluton in $\mathrm{Fe}_{2} \mathrm{O}_{3}$, $\mathrm{FeO}, \mathrm{MgO}, \mathrm{CaO}, \mathrm{TiO}_{2}, \mathrm{MnO}, \mathrm{Co}, \mathrm{Ni}, \mathrm{Cu}, \mathrm{Sc}, \mathrm{Sr}, \mathrm{V}, \mathrm{Y}, \mathrm{Ga}$, and $\mathrm{Yb}$, and lower in $\mathrm{SiO}_{2}, \mathrm{~K}_{2} \mathrm{O}, \mathrm{Ba}$, and differentiation index (Thornton and Tuttle, 1960). However, the dacite dike is more mafic than the granodiorite porphyry dikes, and thus its magma doubtless proceeded farther along the trend line from the parent pluton than did that of the granodiorite porphyry dikes.

The differences between the two trend lines are clear but not profound: the younger Copper Nunataks pluton trend line reflects less quartz but generally higher alkalies and lower contents of $\mathrm{MgO}$ and $\mathrm{CaO}$. The chemical and petrographic differences between the two episodes may be explained largely by differentiation of a magma. The 10-m.y.-age difference between the granodiorite and Copper Nunataks plutons suggests the time frame during which differentiation produced these changes. The lower position of the Copper Nunataks pluton trend line with respect to quartz however, may partly reflect the tapping of magma from a lower level in a compositionally zoned magma chamber as compared with the level of the magma of the granodiorite episode.

\section{TRENDS OF SYSTEMATIC JOINTS}

Steeply dipping systematic joints cut all rocks in the Copper Nunataks. As in rocks of the overall Lassiter Coast (Kellogg and Rowley, 1974), joints may be di- vided into two groups: barren joints and less common epidote-coated joints. Most barren joints (fig. 20) strike north-northeast and east-west; they are probably shear joints. In contrast, most epidote-coated joints strike between north-northwest and west-northwest. They are interpreted as extension joints and mark the position parallel to the direction of maximum principal compressive stress. This strike direction is paralleled by the dacite and granodiorite porphyry dikes and the main mode of aplite-pegmatite dikes of the Copper Nunataks pluton intrusive event; the parallelism suggests intrusion along the extension position and indicates that the stress field direction was long lived. The sheared phyllic-argillic zones (p. 25) also have an average strike of northwest and may reflect vertical movement along the previously established trend of open joints. The direction of maximum principal compressive stress interpreted from trends of Upper Cretaceous dikes and Upper Cretaceous and post(?)-Upper Cretaceous joints is not far removed from that which produced the period of northeast- to north-northeaststriking tight folds sometime between Late Jurassic and Late Cretaceous time (Williams and others, 1972; Kellogg and Rowley, 1974).

\section{OLDER SHEAR FRACTURING, HYDROTHERMAL ALTERATION, AND MINERALIZATION}

The medium-grained granodiorite of Nunataks B and $\mathrm{C}$ was sheared with accompanying minor hydrothermal alteration and mineralization prior to intrusion of the Copper Nunataks pluton. This took place during two events, described by their field names as an early set of crisscrossing "gray shear fractures" and a late set of crisscrossing "black shear fractures;" the late set cut across the early set. The black shear fractures cut the dacite dike; presumably the gray shear fractures also cut the dacite dike, but this was not verified by the field evidence. The gray shear fractures consist of numerous individual fault planes; in most places they are $1-5 \mathrm{~cm}$ wide but locally are as wide as $50 \mathrm{~cm}$. The rock has been mylonitized to a light- to

TABLE 4.- Results of X-ray determination of sheet silicates from hydrothermally altered rocks of the Copper Nunataks, Antarctica

[Sample localities shown in figure 6. Kgd, granodiorite porphyry dike; Kc, Copper Nunataks pluton; Kg, granodiorite pluton. Interpretation of X-ray data by Leonard G. Schultz. Numbers given in estimated percent by volume of total rocks, rounded to nearest 5 . Tr., significant trace, probably several percent; Tr??, possible significant trace; $\leqslant$, less than or equal to; $\equiv$, greater than or equal to]

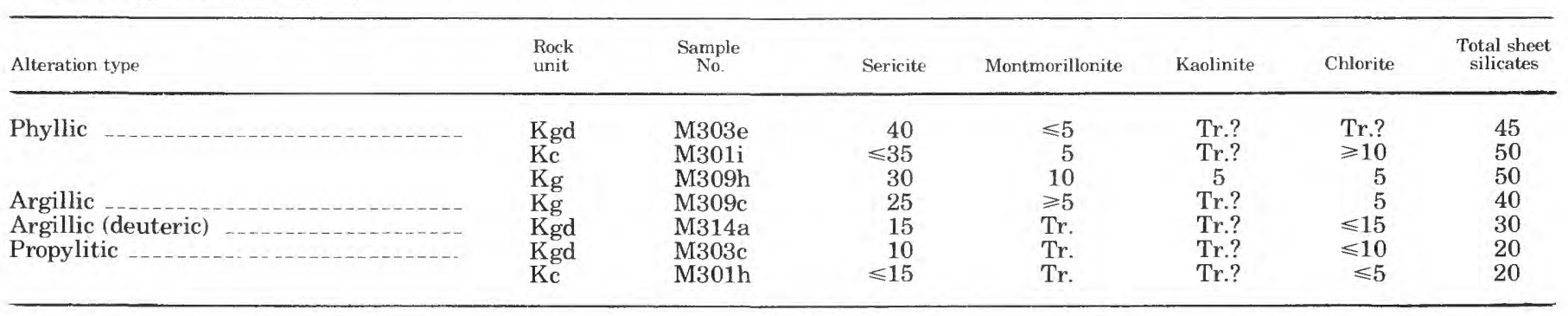




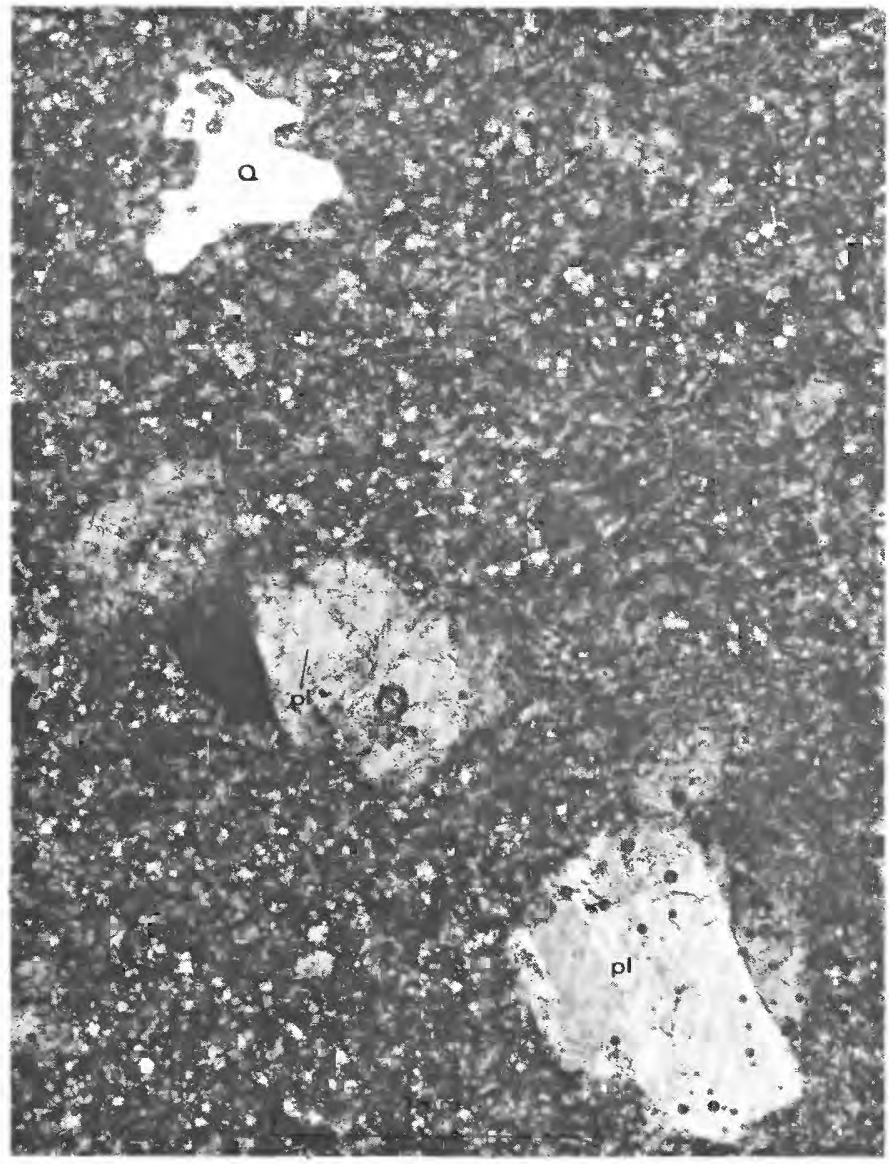

FigURE 16.-Fresh contact phase (chilled margin) of granodiorite porphyry dike: sparse phenocrysts of plagioclase ( $\mathrm{pl}$ ) and embayed "beta" quartz (Q) in a groundmass of fine-grained anhedral K-feldspar, quartz, and lesser plagioclase and hornblende. Specimen M404c. Crossed polars.

medium-gray, fine-grained rock (fig. 9). The black shear fractures consist of numerous individual fault planes that are generally less than $5 \mathrm{~cm}$ wide, but in many places are more than $1 \mathrm{~m}$ wide. The rock has been mylonitized to a black fine-grained rock (fig. 21). Typically, the shear planes of both types of fractures are spaced at intervals of about one-half to several meters. Shear-fracture planes of both the gray and black sets dip steeply and strike in many directions; relative displacement is difficult to determine in this igneous terrane, but where it could be measured, the displacement is from several centimeters to over several meters in a predominantly vertical component. The relatively widespread extent, minor size, and small amount of offset suggest that both shear-fracture sets are probably best considered as the results of crackling or breaking. These two sets occur in the same areas on Nunatak B and are best developed within about $100 \mathrm{~m}$ of the quartz monzonite intrusive contacts; they also overlap each other over most of

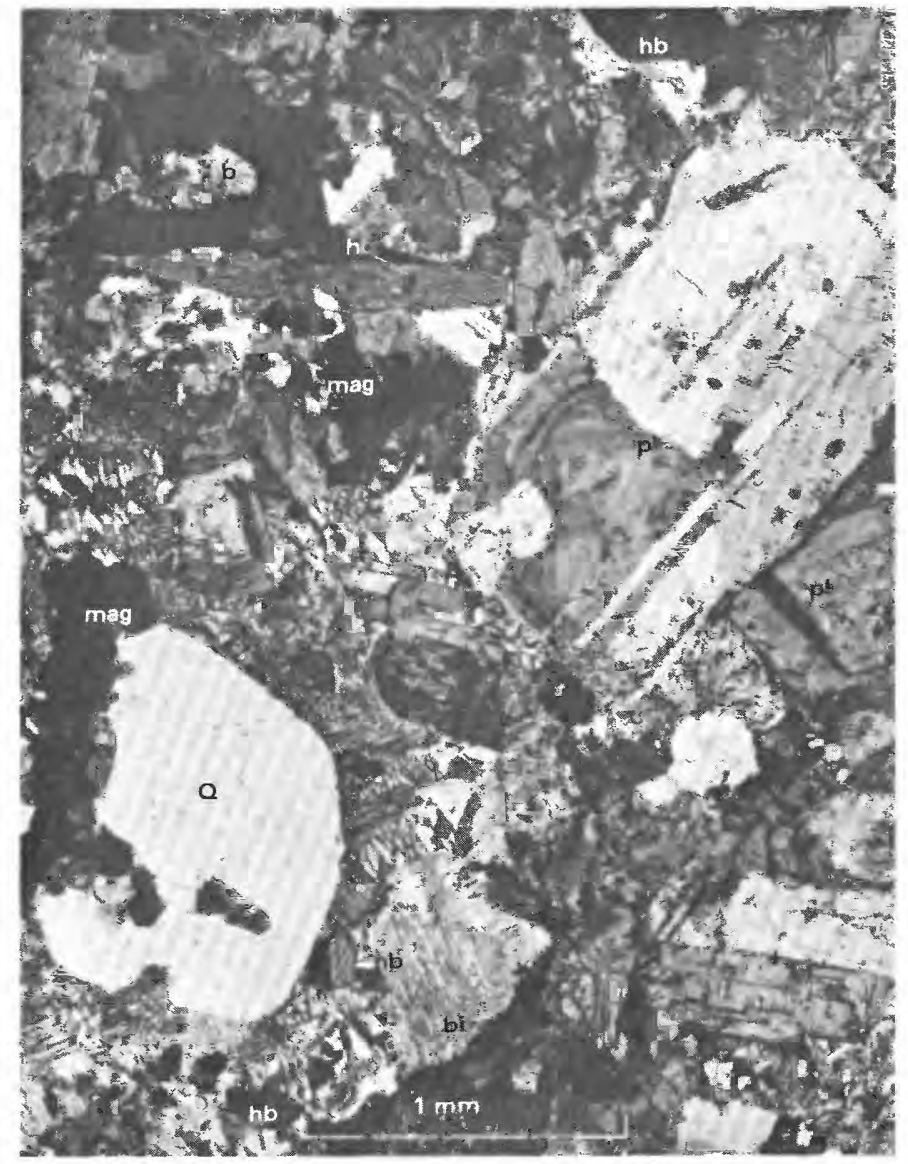

FigURE 17.-Fresh interior phase of a granodiorite porphyry dike: abundant phenocrysts of mostly zoned plagioclase (pl), embayed "beta" quartz (Q), hornblende (hb), partly chloritized biotite (bi), and accessory magnetite (mag) and sphene ( $\mathrm{sp}$ ) in a groundmass of myrmekitic K-feldspar and quartz and lesser hornblende, plagioclase, and opaque minerals. Specimen M311c. Crossed polars.

Nunatak C. Similar shear fractures cut the stoped blocks of granodiorite within the Copper Nunataks pluton at Nunatak A. Minor hydrothermal alteration affects both sets although shearing and alteration is greater along the black shear fractures and is accompanied by minor pyrite mineralization.

Microscopically the mylonite of the gray shearfracture set consists of very fine grained (mostly 10 or $20 \mu \mathrm{m}$ or less) equant anhedral crystals of quartz, less abundant feldspar, minor green hornblende, and traces of magnetite (fig. 22). The wallrock, from the megascopic edge of the shear fracture outward to about $5 \mathrm{~mm}$, exhibits partial recrystallization of much of the feldspar and quartz creating a fine-grained rock similar to that within the shear fracture. Most relic quartz has sutured boundaries, relic green hornblende is fresh but ragged and anhedral, and biotite has recrystallized to clusters of small (less than $0.3 \mathrm{~mm}$ ) randomly oriented brown biotite. This alteration zone rapidly grades into an outer zone $5 \mathrm{~cm}$ wide where only clus- 

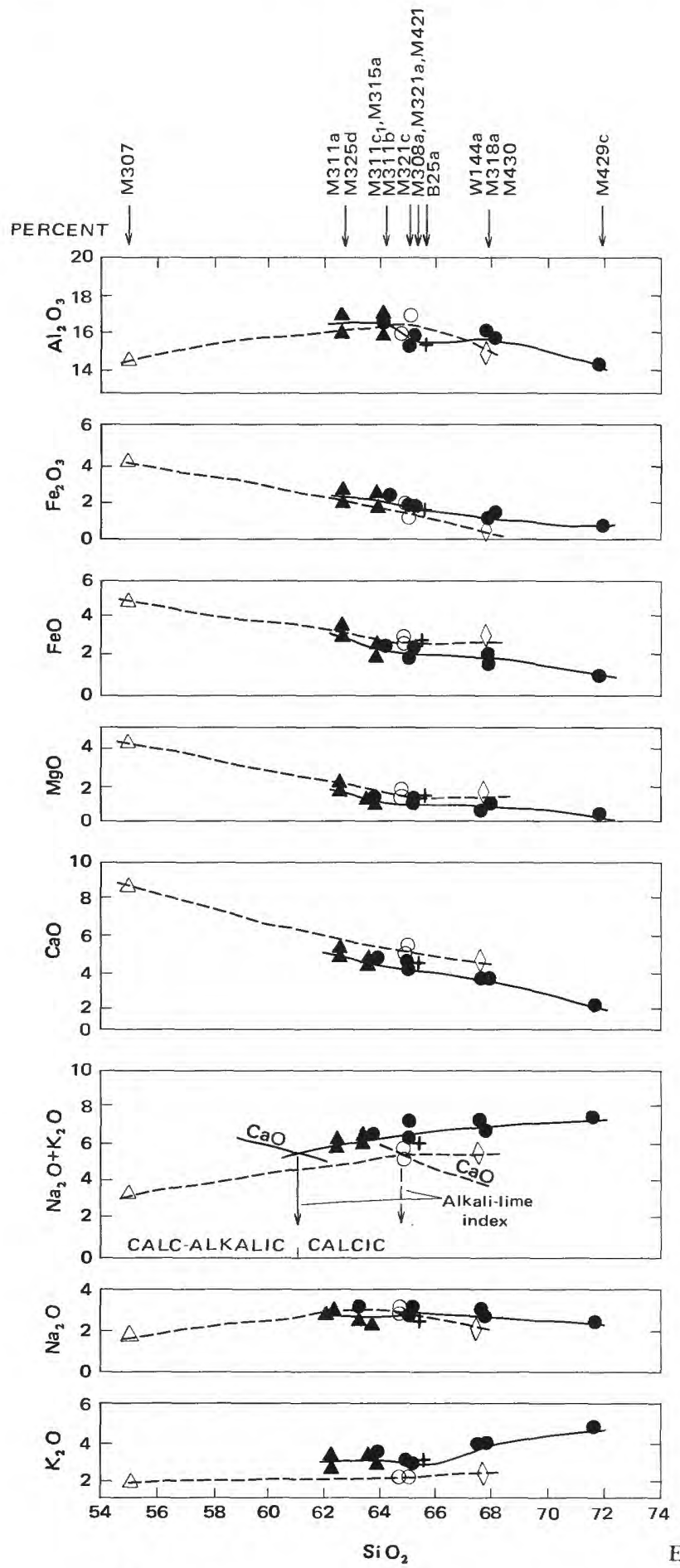

Cretaceous

Younger igneous episode

$\Delta$ Granodiorite porphyry dike

- Quartz monzonite of Copper Nunataks pluton

+ Assimilated rocks - Of same age as Copper Nunataks pluton
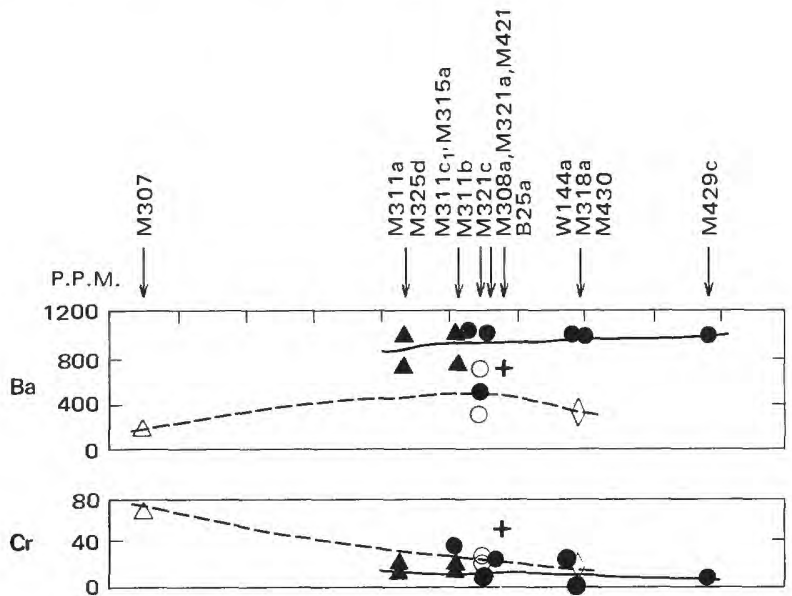

La
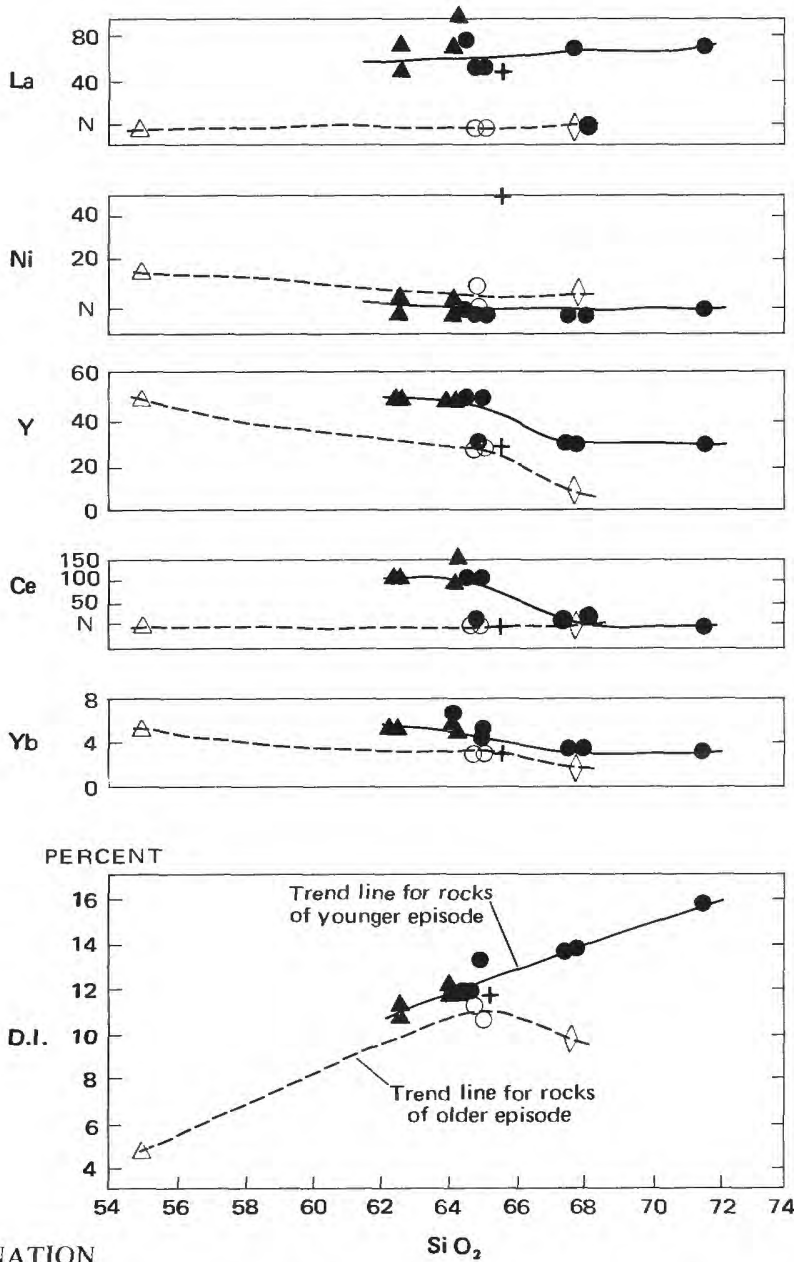

Cretaceous

Older igneous episode

$\triangle$ Dacite dike

Granodiorite pluton

$\checkmark$ West RARE pluton - Of same age as granodiorite pluton

Figure 18.-Variation in common oxides (weight percent), selected trace elements (ppm), and differentiation index plotted against $\mathrm{SiO}_{2}$ (percentage content) for specimens from fresh rocks from the major igneous units, Copper Nunataks. From data in table 2. 

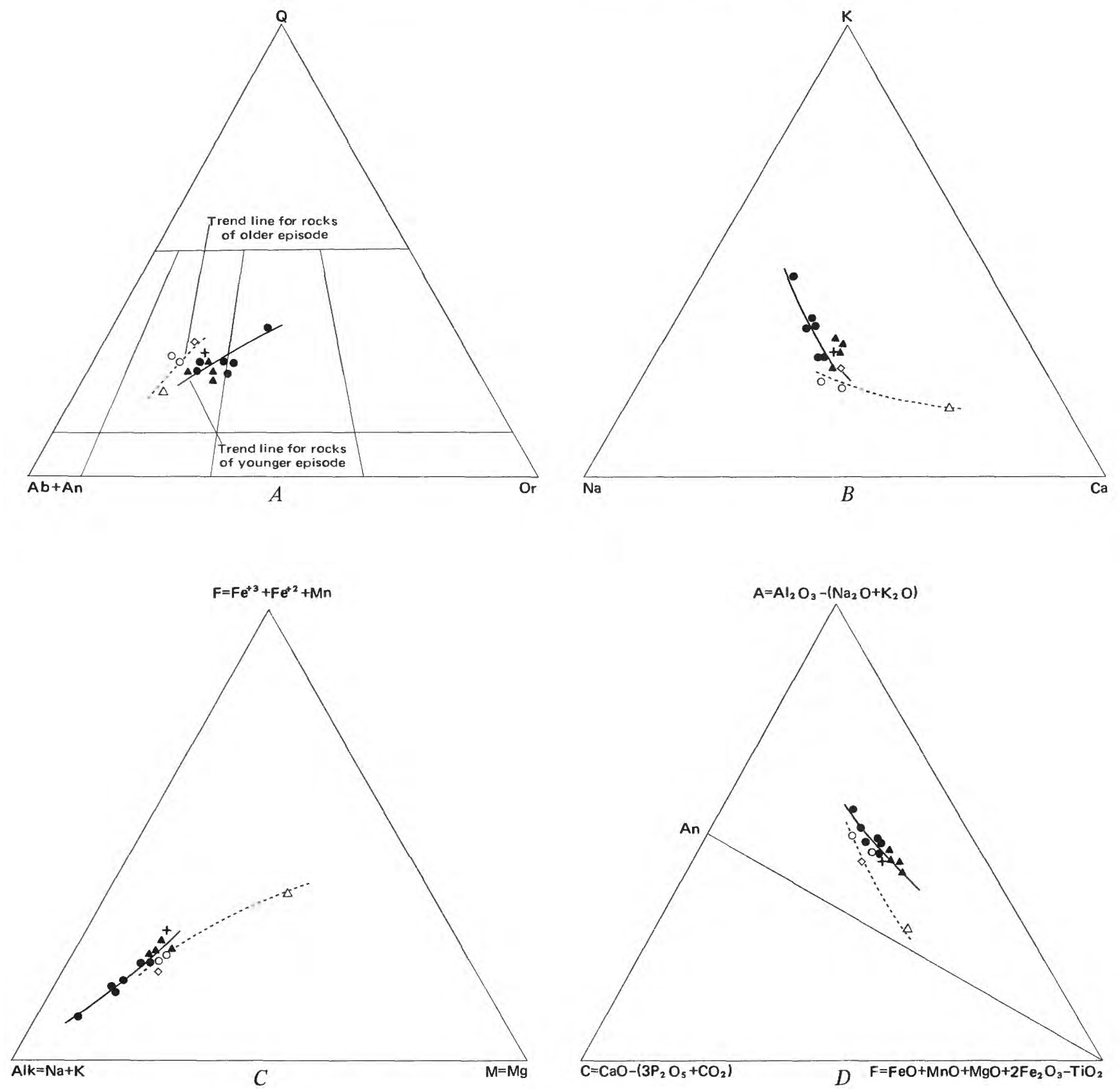

\section{EXPLANATION}

Cretaceous

Younger igneous episode

- Granodiorite porphyry dike

- Quartz monzonite of Copper Nunataks pluton

$+\quad$ Assimilated rocks - Of same age as Copper Nunataks pluton
Cretaceous

Older igneous episode

$\triangle$ Dacite dike

- Granodiorite pluton

- West RARE pluton - Of same age as granodiorite pluton

FIGURE 19.-Ternary plots of selected normative minerals, Barth's cations, and oxides from fresh rocks from the major igneous units, Copper Nunataks. From data and recalculation of data in table 2. (A) Normative quartz-orthoclase-plagioclase (Ab+An), (B) Na-K-Ca (cation percent), (C) Alk-F-M (cation percent), (D) A-C-F (weight percent). 


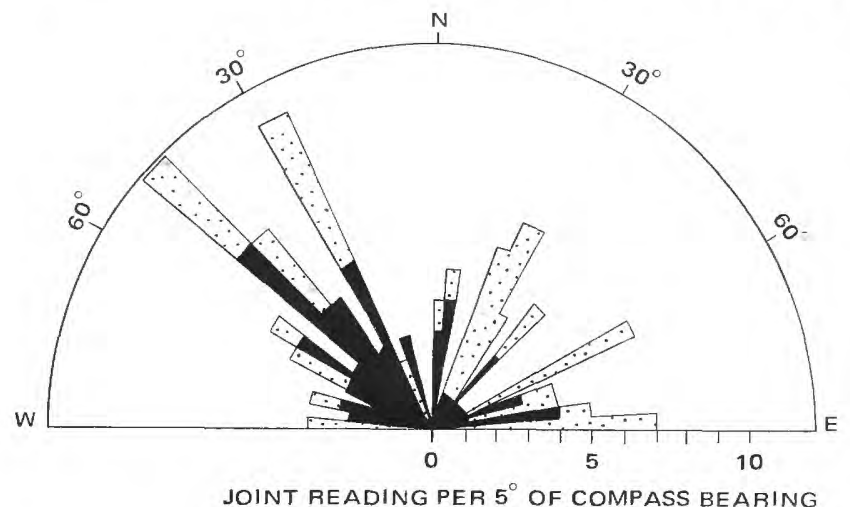

JOINT READING PER $5^{\circ}$ OF COMPASS BEARING

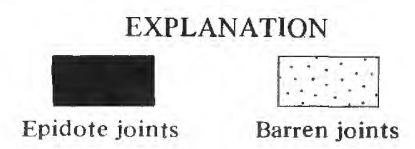

Figure 20.-Rose diagram of strikes of systematic steeply dipping joints in rocks of the Copper Nunataks.

ters of recrystallized biotite distinguish it from fresh rock. Hydrothermally altered rock consists of chloritization of biotite and light to moderate saussuritization of relic feldspars. It occurs within parts of the shear fractures and the adjacent wallrock, but is not necessarily axial to the shear features. A semiquantitative

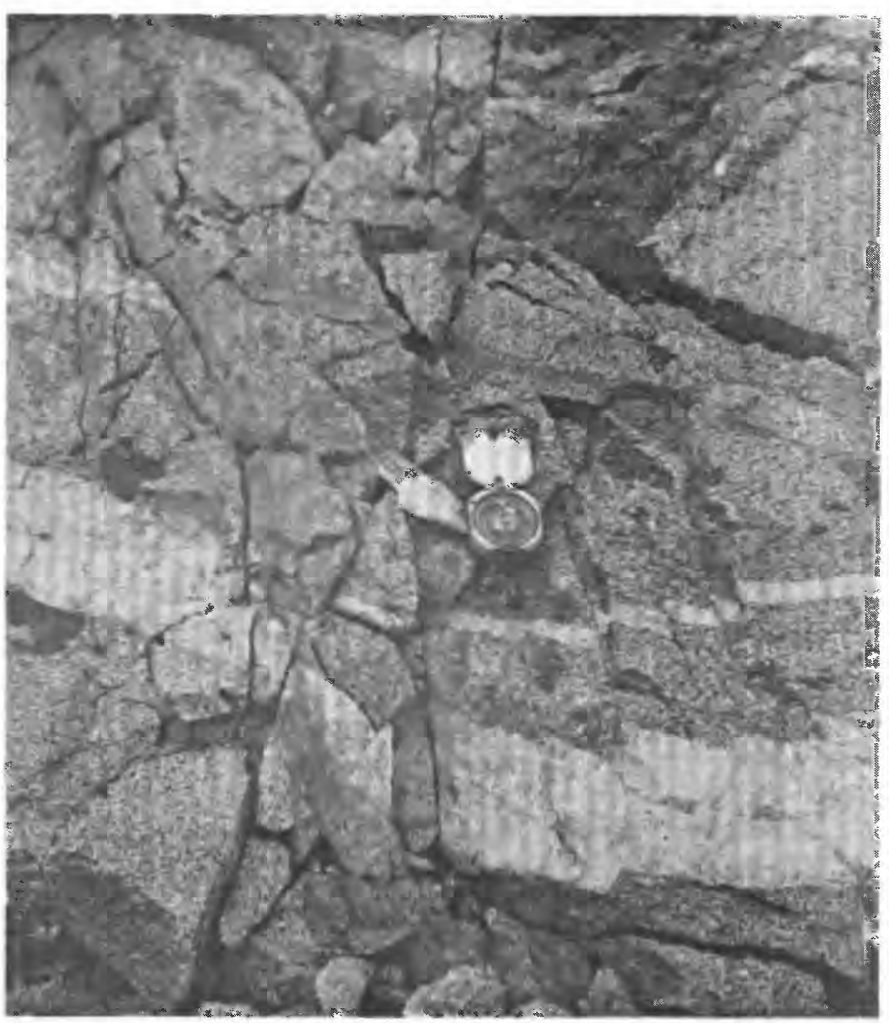

Figure 21.-Pegmatite and aplite dikes at outcrop M300, Nunatak B. The dikes crosscut their parent granodiorite pluton and are offset by a series of parallel small black shear fractures.

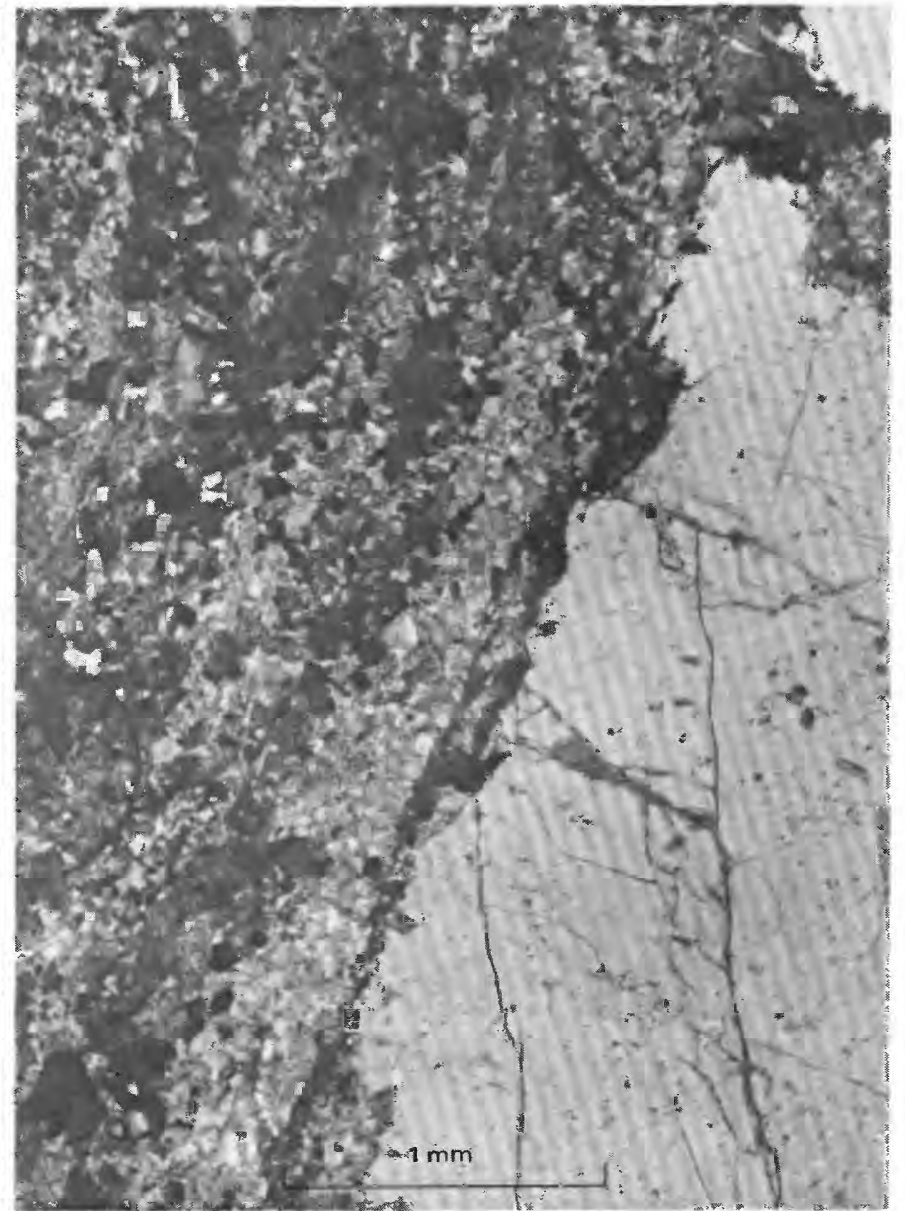

Figure 22.-Edge of a black shear fracture. Sheared and recrystallized fine-grained anhedral crystals of quartz, feldspar, hornblende, and, in smaller amounts, magnetite and pyrite in contact with a partly sheared relic quartz crystal. Specimen S57h. Partly crossed polars.

spectrographic analysis (table 3, sample B26g) reveals that the gray shear-fractures are almost completely devoid of element additions. The rock shows a possible increase in $\mathrm{V}$ and depletions in $\mathrm{Fe}, \mathrm{Mg}, \mathrm{Ca}, \mathrm{Ti}, \mathrm{Mn}, \mathrm{Cr}$, $\mathrm{Sc}, \mathrm{Sr}, \mathrm{Y}, \mathrm{Zr}$, and apparently $\mathrm{Ba}, \mathrm{Be}, \mathrm{Co}, \mathrm{Cu}$, and $\mathrm{Ni}$ relative to fresh rock.

The black shear fractures have significantly more recrystallized and altered rock within their wallrocks than do the gray shear fractures. Furthermore, in several places pyrite veins as much as $5 \mathrm{~mm}$ wide occur in or adjacent to black shear fractures. Microscopic study of nine thin sections reveals that the mylonitized rock in the core of the shear fracture is in large part recrystallized to equant anhedral crystals of quartz, feldspar, hornblende, and opaque minerals that average 10 $100 \mu \mathrm{m}$ in size. Both hornblende and opaque minerals are more abundant (as much as 50 percent by volume) and commonly occur as larger crystals (as much as $1 \mathrm{~mm}$ ) in black shear fractures than in the gray shear 
fractures. In many rocks pyrite makes up most of the opaque minerals, and the abundance of ferromagnesian minerals undoubtedly causes the black color in the shear fractures. In some places the shear fractures contain sparse to abundant, sheared and recrystallized fragments of wallrock and coarse-grained quartz. The feldspar and quartz in the wallrock is partially but extensively recrystallized to a fine-grained quartzfeldspar rock similar to that within the shear fractures for at least $3 \mathrm{~cm}$ outward from the shear fracture. Relic wallrock in and about $5 \mathrm{~mm}$ beyond this zone lacks biotite and contains introduced pyrite and possibly magnetite. Hornblende occurs as fresh anhedral poikilitic crystals, either relic or replacing biotite; plagioclase is at least slightly saussuritized. Rock about $1 \mathrm{~cm}$ beyond this zone is relatively fresh but, like the wallrock near the gray shear fractures, original biotite has been recrystallized into clusters of randomly oriented, small (maximum $0.3-0.4 \mathrm{~mm}$ ) crystals. This rock in turn grades into fresh wallrock 4 or $5 \mathrm{~cm}$ beyond the edges of even the smallest shear fractures. The shear fractures are commonly hydrothermally altered, but maximum alteration does not necessarily coincide with the central part of the shear fracture. Alteration within the shear fracture results in extensive saussuritization of feldspar, chloritization of biotite, and occasionally moderate epidotization of plagioclase and biotite. Hydrothermal alteration is presumed synchronous with crackling. Semiquantitative spectrographic analyses of nine black shear fractures (table 3 ) shows some changes in elements by alteration solutions relative to that of fresh rock. The analyses show that $\mathrm{Fe}, \mathrm{Mg}, \mathrm{Mn}, \mathrm{Co}, \mathrm{Cr}, \mathrm{Cu}, \mathrm{Mo}, \mathrm{Ni}, \mathrm{Pb}$, and $\mathrm{V}$ have been introduced, and $\mathrm{Al}, \mathrm{Na}, \mathrm{Ca}, \mathrm{Ba}, \mathrm{Sr}, \mathrm{Y}, \mathrm{Yb}$, and $\mathrm{Zr}$ have been lost.

\section{YOUNGER SHEAR-FRACTURING, HYDROTHERMAL ALTERATION, AND MINERALIZATION}

Following intrusion of the granodiorite porphyry dikes, rocks at scattered places in Nunataks A, B, and $\mathrm{C}$ were sheared to various degrees with accompanying hydrothermal alteration and mineralization. The end result of these associated events, which terminated the Copper Nunataks pluton intrusive episode, was the Lassiter Coast copper deposit.

Shearing took place along narrow linear "sheared phyllic-argillic zones" that crosscut all igneous rocks in the area (figs. $4,23 A, B, C, D$ ). Mineralization consisted mostly of copper and iron sulfides and oxides occurring both as disseminations and as concentrated masses (as much as $10 \mathrm{~cm}$ across) in veins of coarsegrained quartz and in altered wallrock. Most mineralized rock occurs at Nunatak $\mathrm{C}$, with a lesser amount at Nunatak B, and a minor amount at Nunatak A. Mineralized rock is most abundant where sheared phyllic-argillic zones are most abundant; however, it rarely occurs within such zones but is usually found adjacent to them. Most mineralized rock is in the granodiorite batholith within several hundred meters of the Copper Nunataks pluton contact. This localization of mineralized rock probably is caused by two factors-the great abundance here of sheared phyllicargillic zones and the great amount of fracturing (including both gray and black shear-fracturing) that this rock has undergone; both factors provide pathways for mineralizing solutions. Mineralization and alteration are considered to be genetically related to, and roughly simultaneous with, each other.

Sheared phyllic-argillic zones are made up of lighttan to medium-brown hydrothermally altered rock. They range in width from less than a centimeter to at least $20 \mathrm{~m}$, averaging $1-2 \mathrm{~m}$. All sheared phyllicargillic zones are vertical to steeply dipping and most strike west-northwest (the dominant direction at Nunataks A and B) to north-northwest (at Nunatak C) (fig. 23D). Unlike the gray and black shear fractures characterized by mylonite and only lesser altered rock, sheared phyllic-argillic zones are recognized by intensely altered rock with only minor volumes of observed slickensides or mylonite. Phyllic and argillic altered rock (terminology of Lowell and Guilbert, 1970) and minor silicified rock characterize the zones. The contact between zones and less intensely altered propylitic rock (Lowell and Guilbert, 1970) is gradational within $10 \mathrm{~cm}$ in most places, and thus it is well defined. Propylitic altered rock extends for several meters to several tens of meters beyond the edges of the zones, and there it grades into fresh rock. Sheared phyllic-argillic zones are best developed at Nunatak C. Here all rock is transected by zones of various widths occurring at intervals of from several meters to about $10 \mathrm{~m}$; thus all rock at Nunatak C is altered to some degree by either sheared phyllic-argillic zones or intervening propylitic rock. Phyllic-argillic altered rock at Nunataks A and B is restricted to several zones less than $3 \mathrm{~m}$ wide.

Where offset could be determined for the sheared phyllic-argillic zones, it is vertical and commonly less than several meters (fig. 23D); some aplite-pegmatite dikes cut by sheared phyllic-argillic zones are not offset. However, two zones at Nunatak B have relatively large measurable displacement. The westnorthwest-striking fault at the northwestern part of the nunatak (fig. 4) cuts the subvertical dacite dike, subvertical granodiorite dike, and east-dipping quartz monzonite contact with right-lateral apparent offset of 

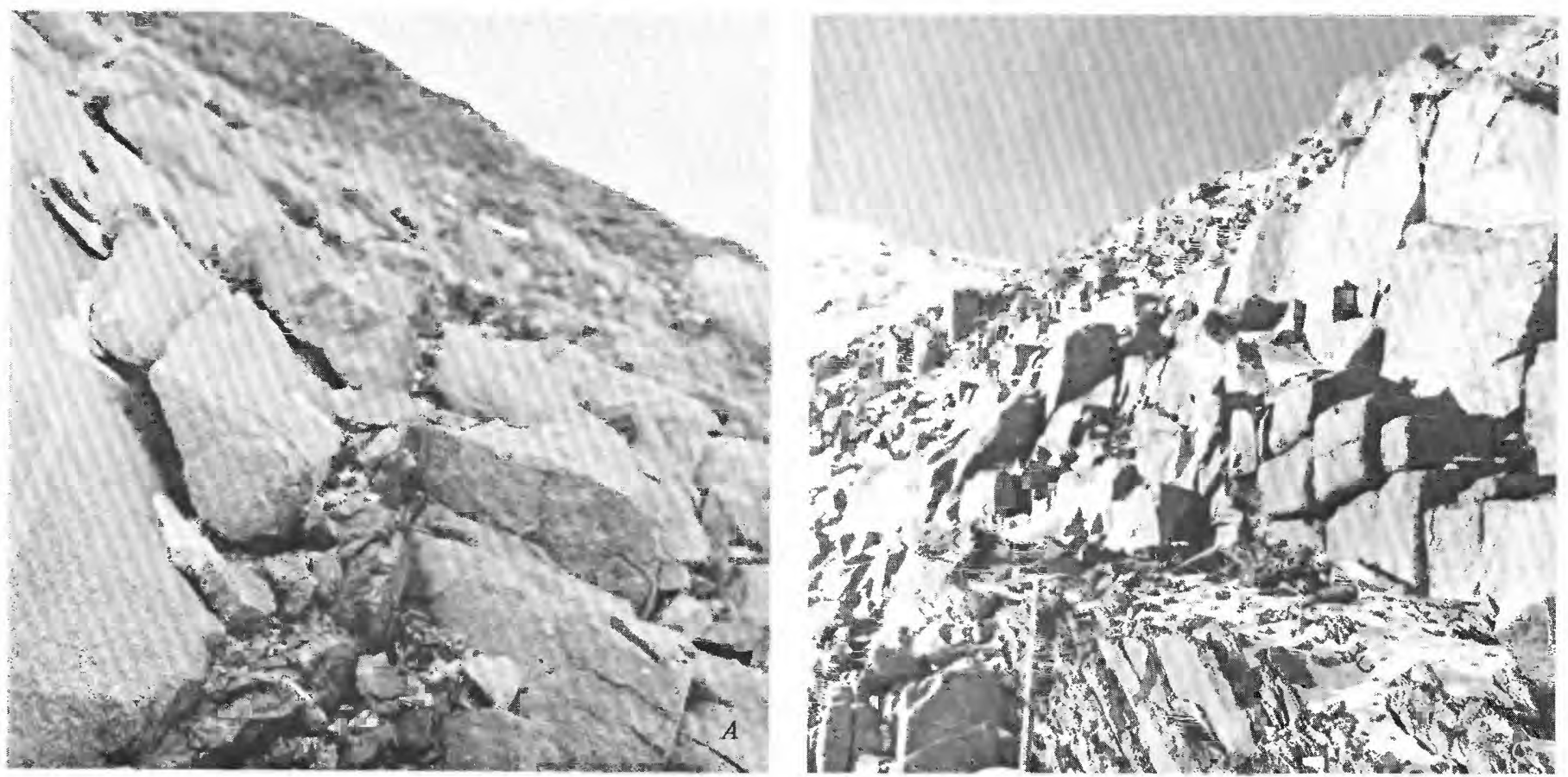

FIGURE 23.-Sheared phyllic-argillic zones.

$A$, Narrow $(10 \mathrm{~cm})$ northwest-striking zone cutting lighter colored rock of Copper Nunataks pluton, outcrop M301, Nunatak B.

$C$, Dark, relatively crumbly rock of a sheared zone near the ice ax, at outcrop M317, Nunatak A. Lighter, more resistant, fresh to propylitic altered rock of the Copper Nunataks pluton makes up the jointed northwest-trending face.
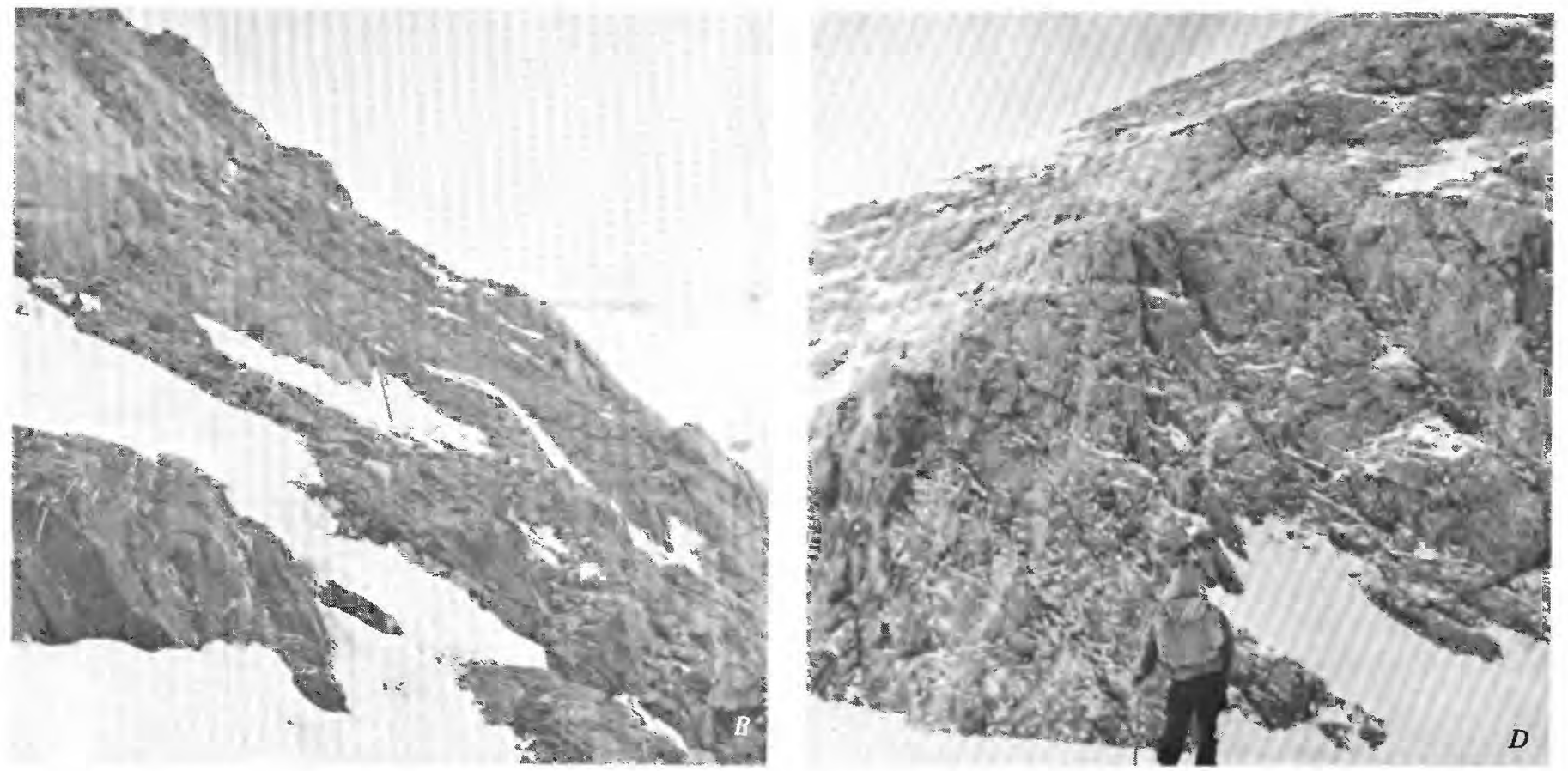

$B$, Darker and mostly weaker rocks of several bifurcating $1-3 \mathrm{~m}$ wide zones that transect rock of the Copper Nunataks pluton. View is southeast along strike of the zone from outcrop M301, Nunatak B. The areas of lowest relief and the rock fragments of smallest size mark the axial, most intensely altered parts of the zones. The freshest rock shown is the lighter colored propylitic altered rock in the upper left corner. Ice ax in center of photograph for scale.

$D$, A series of small parallel sheared phyllic-argillic zones, striking to the upper left (northwest) and dipping steeply to the right (northeast) at outcrop M326, Nunatak C. Note offset of a subvertical pegmatite dike by several sheared zones, left and above the man's head. Most of the outcrop is rock of the granodiorite pluton. 
about $10 \mathrm{~m}, 20 \mathrm{~m}$, and $100 \mathrm{~m}$, respectively. The best estimate of actual displacement is that the north block was upthrown relative to the south block at least 50 $100 \mathrm{~m}$. The north-northeast-striking fault near the eastern end of the nunatak requires one of the following: at least $50-100 \mathrm{~m}$ of vertical component displacement, about $20 \mathrm{~m}$ of left-lateral strike-slip movement, or a combination of both in order to offset the subvertical dacite dike as shown on the map (fig. 4). Elsewhere on the Lassiter Coast, significant high-angle faulting has not been found. Therefore we consider offset associated with the sheared phyllic-argillic zones to be a localized breaking due to late-stage igneous movement; it probably does not represent regional tectonism.

\section{MINERALIZATION}

The Lassiter Coast copper deposit consists of coarsely disseminated hypogene sulfide and oxide minerals and quartz veins containing hypogene sulfide and oxide minerals. Minerals are most abundant in nunataks where sheared phyllic-argillic zones are most abundant; minerals usually occur in propylitically altered rock and are sometimes found in the sheared phyllic-argillic zones themselves. Field evidence on the relative ages of minerals and sheared phyllic-argillic zones is unequivocal in four locations at Nunatak C. Here quartz veins and minerals appear to cut sheared phyllic-argillic zones in some places, but in two outcrops sheared phyllic-argillic zones cut quartz veins. We conclude that mineralization and shearingalteration probably were nearly concurrent, but mineralization locally may have predated shearing and alteration slightly.

Mineralized quartz veins do not appear to have alteration envelopes of their own. They have an average width of $2 \mathrm{~cm}$ and may be more than $10 \mathrm{~cm}$ wide, which is unusually wide for veins of porphyry deposits. Most mineralized quartz veins occur at Nunatak $\mathrm{C}$ and the western half of Nunatak B, where they are irregularly spaced at intervals of from several meters to a dozen meters. Thus they are generally widely scattered, another feature dissimilar to those of porphyry deposits; more than one quartz vein rarely crops out within an area of a square meter. Most veins consist largely of quartz, with few or no megascopic sulfide and oxide minerals. Some veins, however, consist largely of opaque minerals. The principal opaque vein minerals are magnetite, pyrite, chalcopyrite, and molybdenite; in some places lenticular masses as much as several tens of centimeters long consist of fine- to coarsegrained epidote. Minor hornblende may accompany magnetite.

Disseminated sulfides and oxides are slightly more abundant than veins and occur as either single crystals or elongated masses as much as $10 \mathrm{~cm}$ long. These sulfides and oxides are found mostly at Nunatak $\mathrm{C}$ and in the western half of Nunatak B. They occur as bodies of disseminated crystals or clots several cubic meters in size or as widely distributed crystals or clots irregularly spaced anywhere from several to $20 \mathrm{~m}$. Finely disseminated minerals also occur locally in the chilled margins of the granodiorite porphyry dikes. Thus disseminated minerals also are much coarser grained and more widely scattered than those in commercial porphyry copper deposits; nowhere did we find large outcrops comprised of finely disseminated sulfides. Chalcopyrite and pyrite are the most common ore minerals, whereas molybdenite is uncommon. In some places clots are concentrically zoned with chalcopyrite more abundant near the center and pyrite and limonite more abundant on the margins. Most disseminated crystals or clots are surrounded by halos of rusty limonite and (or) bright-yellow oxide stains extending $10 \mathrm{~cm}$ or more beyond the edges of the sulfide minerals.

Supergene minerals are rare in this extremely arid region where ground water is absent. Malachite and possibly chrysocolla, however, are conspicuous in many places adjacent to concentrations of hypogene copper minerals and occur as small crusts that rarely exceed several square centimeters in size. Limonite and hematite occur in cracks or surround magnetite, pyrite, and chalcopyrite.

Examination of 7 thin sections and 13 polished sections shows that the major copper mineral is chalcopyrite; malachite, chalcocite, and possibly bornite are rare. Pyrite crystals and leafy masses (as much as several centimeters long) of molybdenite are commonly intimately associated with the copper minerals. Magnetite is one of the most abundant opaque minerals in the veins and occurs either in massive form as much as $10 \mathrm{~cm}$ in diameter or as small to mediumgrained plates or radiating plates. Magnetite masses may occur alone or may be associated with all or some of the other minerals. Limonite and hematite are mostly secondary and form rims in cavities adjacent to magnetite, pyrite, and chalcopyrite.

In many places the wallrock adjacent to ore minerals is remarkably fresh with only minor epidotization of plagioclase and minor chloritization of biotite. In other places feldspar is moderately to highly altered to sericite and clay minerals, biotite is altered to chlorite and epidote, hornblende is altered to uralite, magnetite is partially altered to hematite, and rutile and limonite are present. In some areas biotite is recrystallized to clusters of tiny, randomly oriented crystals, and feldspar is partly recrystallized to fine-grained anhedral quartz-feldspar masses; quartz is increased in volume by addition of rims of fine-grained quartz crystals. Al- 
tered rock generally grades into fresh rock within 1 or $2 \mathrm{~cm}$ from the ore minerals.

Most rocks from mineralized areas (table 3, 19 semiquantitative spectrographic analyses) show increases in $\mathrm{Fe}, \mathrm{Ag}, \mathrm{Bi}, \mathrm{Co}, \mathrm{Cu}, \mathrm{Mo}, \mathrm{Ni}, \mathrm{Pb}$, and $\mathrm{Zn}$, and depletions in $\mathrm{Al}, \mathrm{Mg}, \mathrm{Ca}, \mathrm{Na}, \mathrm{K}, \mathrm{Mn}, \mathrm{Ti}, \mathrm{Ba}, \mathrm{Be}, \mathrm{Cr}, \mathrm{La}$, $\mathrm{Sc}, \mathrm{Sr}, \mathrm{Y}, \mathrm{Yb}$, and $\mathrm{Zr}$. Trace element changes are similar to, but greater than, those due to sheared phyllicargillic zones. Highest values were recorded for the quartz veins. A few of these quartz veins locally contain over 10 percent $\mathrm{Fe}$ by weight, 3 percent $\mathrm{Cu}, 0.7$ percent $\mathrm{Pb}, 0.15$ percent $\mathrm{Mo}, 700 \mathrm{ppm} \mathrm{Zn}, 700 \mathrm{ppm} \mathrm{Bi}$, $500 \mathrm{ppm} \mathrm{W}$, and $300 \mathrm{ppm} \mathrm{Ag}$. The grade of the rock at Nunatak C, where sulfides are most abundant, probably does not average over $200 \mathrm{ppm} \mathrm{Cu}$ or $100 \mathrm{ppm} \mathrm{Pb}$, and averages less than $50 \mathrm{ppm} \mathrm{Mo-and} \mathrm{such} \mathrm{values}$ are well below ore grade for commercial porphyry copper deposits.

In line with recent studies of copper content in biotites of plutons associated with copper deposits (for example, Lovering and others, 1970; Banks, 1974), semiquantitative spectrographic analyses were determined for a biotite-hornblende separation from three samples each of the granodiorite batholith, Copper Nunataks pluton, and granodiorite porphyry dikes. All samples were fresh rocks collected from three of the major nunataks (fig. 6). The results of the nine analyses (table 5) show that neither copper nor any other minor elements added during mineralization are concentrated to any significant degree in the biotite or hornblende of the associated fresh igneous units.

\section{PHYLLIC AND ARGILLIC ALTERATION}

Most sheared phyllic-argillic zones contain a medium-brown, completely sericitized rock and a less altered rock in which feldspar is tan or brownish pink owing to various stages of alteration and biotite is altered to green chlorite. The former rock type (mostly "phyllic alteration" of Lowell and Guilbert (1970); "sericitic alteration" of Meyer and Hemley (1967)) generally occupies the more central parts of the zones, and the latter rock (mostly "argillic alteration") occupies the outer parts; but the two are mutually gradational and were not differentiated in the mapping or in this discussion. "Potassic" altered rock may occur locally in some or most sheared phyllic-argillic zones but it does not appear to make up significant parts of the zones. Phyllic altered rock generally weathers easily to medium-brown pebble- or sand-size grus and produces long linear "trenches" on the outcrop. The grade of alteration in some small shear fractures is only argillic. Eleven thin sections of phyllic and argillic rock (five from the granodiorite, four from the Copper Nunataks
TABLE 5.-Semiquantitative spectrographic analyses of biotitehornblende separates from fresh igneous rocks in the Copper Nunataks, Antarctica

[Sample localities shown in figure 6. Kg. granodiorite pluton: Kc, Copper Nunataks pluton Kgd, granodiorite porphyry dike. Analyses by L. A Bradley. Not detected or at limit of detection: Ag, As, Au, B. Bi, Cd. Eu, Ge, Hf, In, Li, P. Pd, Pf, Re, Sb, Sm, Ta, Te, Th, Tl, U. W Zn. Looked for when Y found but not found: Dy, Er, Gd, Ho. Lu, Tb, Tm Not looked for: $\mathrm{Pr}$. detected but below limit of determination]

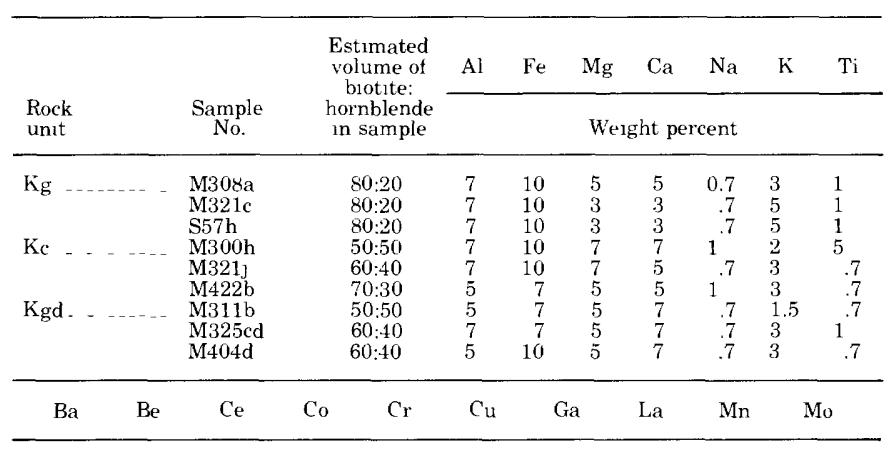

\begin{tabular}{|c|c|c|c|c|c|c|c|c|c|}
\hline \multicolumn{10}{|c|}{ Parts per million } \\
\hline 500 & $\mathrm{~L}$ & L & 50 & 50 & 30 & 20 & $\mathrm{~N}$ & 3,000 & N5 \\
\hline 300 & $\mathrm{~N}$ & $\mathrm{~L}$ & 50 & 50 & 7 & 20 & 50 & 3,000 & N5 \\
\hline 300 & $\mathrm{~N}$ & $\mathrm{~L}$ & 30 & 70 & 15 & 20 & $\mathrm{~N}$ & 3,000 & N5 \\
\hline 70 & 2 & $\mathrm{~L}$ & 30 & 15 & 3 & 20 & 50 & 3,000 & 15 \\
\hline 700 & 2 & $\mathrm{~L}$ & 50 & 15 & 3 & 20 & 70 & 5,000 & N5 \\
\hline 500 & 3 & $\mathrm{~L}$ & 30 & 15 & 7 & 20 & 50 & 3.000 & N5 \\
\hline 150 & $\mathrm{~L}$ & $\mathrm{~L}$ & 20 & 15 & 30 & 20 & 70 & 3,000 & N5 \\
\hline 150 & 1.5 & 200 & 30 & 50 & 30 & 20 & 100 & 3,000 & N5 \\
\hline 700 & $\mathrm{~L}$ & $\mathrm{~L}$ & 30 & 15 & 7 & 20 & 70 & 3,000 & N5 \\
\hline $\mathrm{Nb}$ & $\mathrm{Nd}$ & $\mathrm{N}_{1}$ & $\mathrm{~Pb}$ & $\mathrm{Sc}$ & $\mathrm{Sr}$ & $\mathrm{V}$ & $\mathrm{Y}$ & $\mathrm{Yb}$ & $Z \mathrm{rr}$ \\
\hline \multicolumn{10}{|c|}{ Parts per million } \\
\hline 15 & $\mathrm{~L}$ & 30 & $\mathrm{~N}$ & 70 & 70 & 500 & 50 & 7 & 70 \\
\hline 20 & 100 & 30 & $\mathrm{~N}$ & 70 & 70 & 300 & 70 & 7 & 100 \\
\hline 20 & $\mathrm{~L}$ & 30 & 15 & 70 & 70 & 500 & 50 & 7 & 70 \\
\hline 10 & $\mathrm{~L}$ & 15 & $\mathrm{~N}$ & 70 & 70 & 300 & 30 & - & 70 \\
\hline 15 & $\mathrm{~L}$ & 15 & 10 & 100 & 30 & 300 & 30 & 5 & 150 \\
\hline 20 & $\mathrm{~L}$ & 15 & 15 & 70 & 70 & 200 & 30 & 7 & 100 \\
\hline 15 & 150 & 10 & $\mathrm{~L}$ & 70 & 150 & 300 & 70 & 7 & 100 \\
\hline 20 & 150 & 15 & 10 & 70 & 300 & 300 & 70 & 7 & 100 \\
\hline 15 & 150 & 10 & 20 & 70 & 150 & 300 & 70 & 7 & 70 \\
\hline
\end{tabular}

pluton, two from the granodiorite porphyry) were studied.

Phyllic rock is mostly intensely altered, and it consists almost entirely of quartz and fine-grained sericite and clay (figs. 24, 25, 26). Most quartz forms relic crystals containing some secondary growth on the outside of the crystals, and it has undulose extinction and irregular to vaguely sutured boundaries. All feldspars have been recrystallized to fine-grained sericite and clay. Biotite alters to mostly fine- or medium-grained sericite; the sericite commonly is associated with minor leucoxene and limonite. Hornblende changes to fine-grained sericite and lesser leucoxene, rutile(?), limonite, and hematite; the oxide minerals sometimes occur as a rim around the sericitized crystals. Hematite blades lace some altered hornblende crystals. Calcite may be present in the rock. Opaque minerals consist of minor magnetite-limonite and pyrite; sphene is altered to leucoxene. Tiny sericite veins are locally visible in some thin sections. In less altered rocks, patches of fresh K-feldspar show through the sericite and clay. 


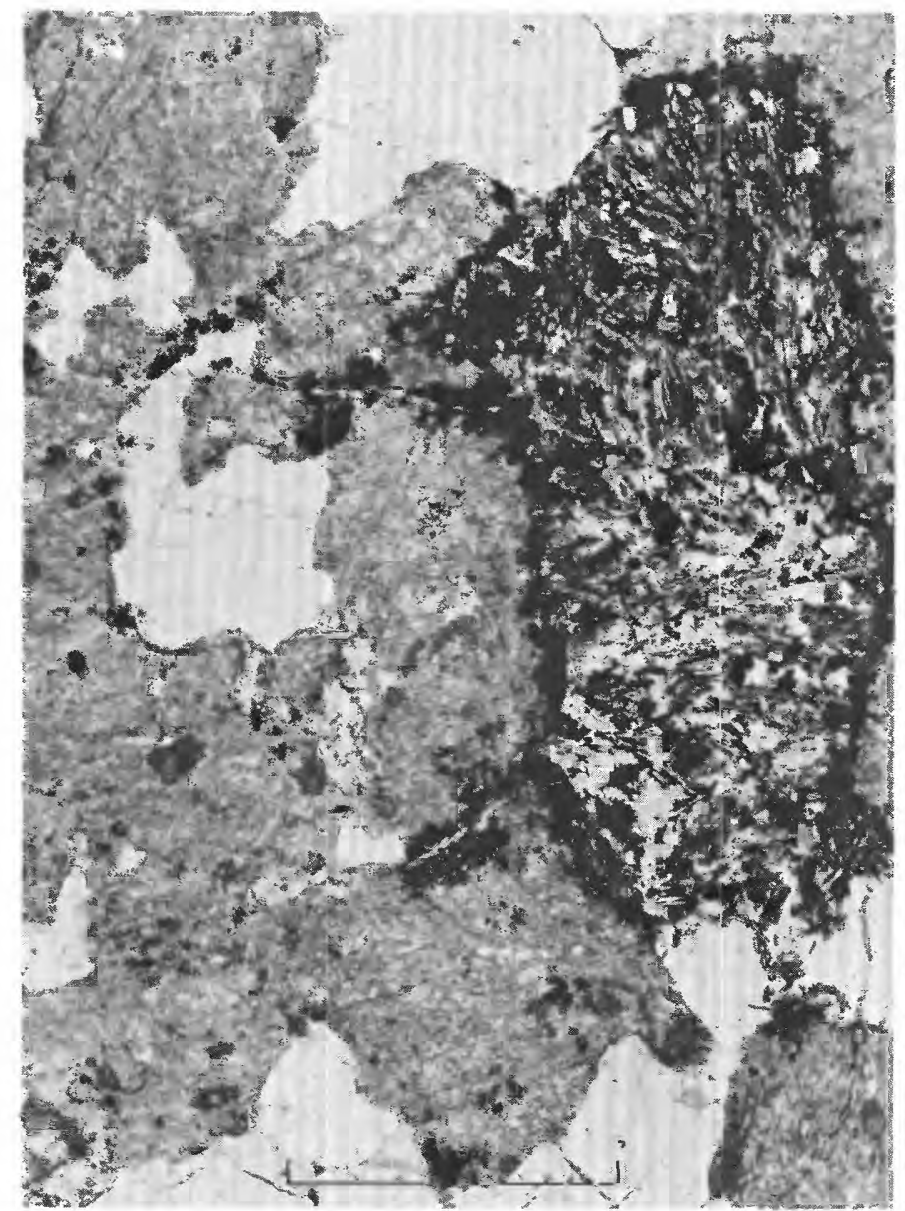

FIGURE 24.-Phyllic altered rock of the granodiorite pluton: all feldspar (light gray in photo) is converted to fine-grained sericite and clay, and relic quartz (white) remains. Hornble nde crystal is converted to medium-grained sericite spotted with leucoxene and is surrounded by a dark limonite-hematite rim. Specimen M309h. Plane light.

In argillic rock, plagioclase is moderately to completely converted to sericite, clay minerals, and minor calcite, and K-feldspar is slightly altered to sericite and clay (fig. 27). Biotite is moderately to totally altered to chlorite (penninite?), minor leucoxene, and rare epidote. Hornblende is either fresh or moderately altered to chlorite and subordinate leucoxene, hematite, limonite, sericite, and minor epidote. Accessory minerals include magnetite, hematite, and pyrite; sphene may be totally altered to leucoxene. Relic quartz with secondary growth and uralite after hornblende develops with more intense alteration.

$\mathrm{X}$-ray studies (table 4) show that total sheet-silicate content is greater in the phyllic rocks than in the argillic rocks. Sericite is most abundant in both alteration types. Montmorillonite is significantly higher and kaolinite may be higher in phyllic rocks than in argil-

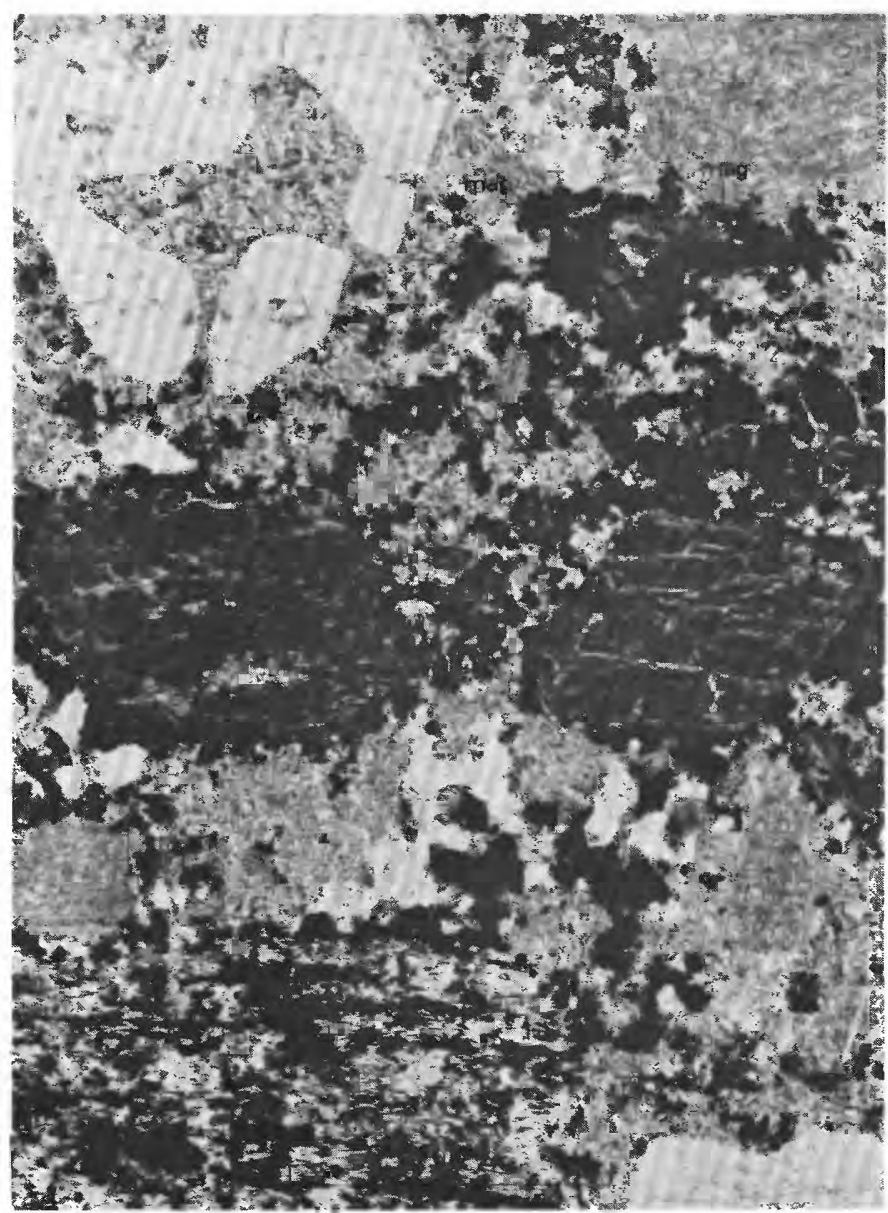

FIGURE 25,-Phyllic altered rock of the granodiorite porphyry dike: all feldspar, which occurs as phenocrysts and in the groundmass, is altered to fine-grained sericite and clay (light gray in photo), whereas relic embayed "beta" quartz phenocryst (upper left) and quartz in the groundmass remain largely unchanged. The biotite phenocryst (lower left) is altered to medium-grained sericite spotted with leucoxene and limonite-hematite. Two large dark hornblende phenocrysts (center) are altered to fine-grained sericite-leucoxene and are largely rimmed by limonite-hematite. Several small crystals of magnetite (mag) are laced with hematite. Specimen M303e. Plane light.

lic rocks. Chlorite is less abundant in phyllic rocks than in argillic rocks.

Semiquantitative spectrographic analyses of 20 samples from sheared phyllic-argillic zones (table 3) show that $\mathrm{Cu}, \mathrm{Pb}, \mathrm{Mo}$, and probably $\mathrm{Ni}, \mathrm{Ag}$, and $\mathrm{Bi}$ were introduced, and that $\mathrm{Al}, \mathrm{Na}, \mathrm{Ba}$, and probably $\mathrm{Mg}, \mathrm{Sr}, \mathrm{Y}$, and $\mathrm{Zr}$ were depleted.

\section{PROPYLITIC ALTERATION}

Phyllic-argillic altered rock grades sharply into propylitic rock over several centimeters or even over several millimeters. Study of six thin sections (two of the granodiorite, two of the Copper Nunataks pluton, two of the granodiorite porphyry) shows that altered 


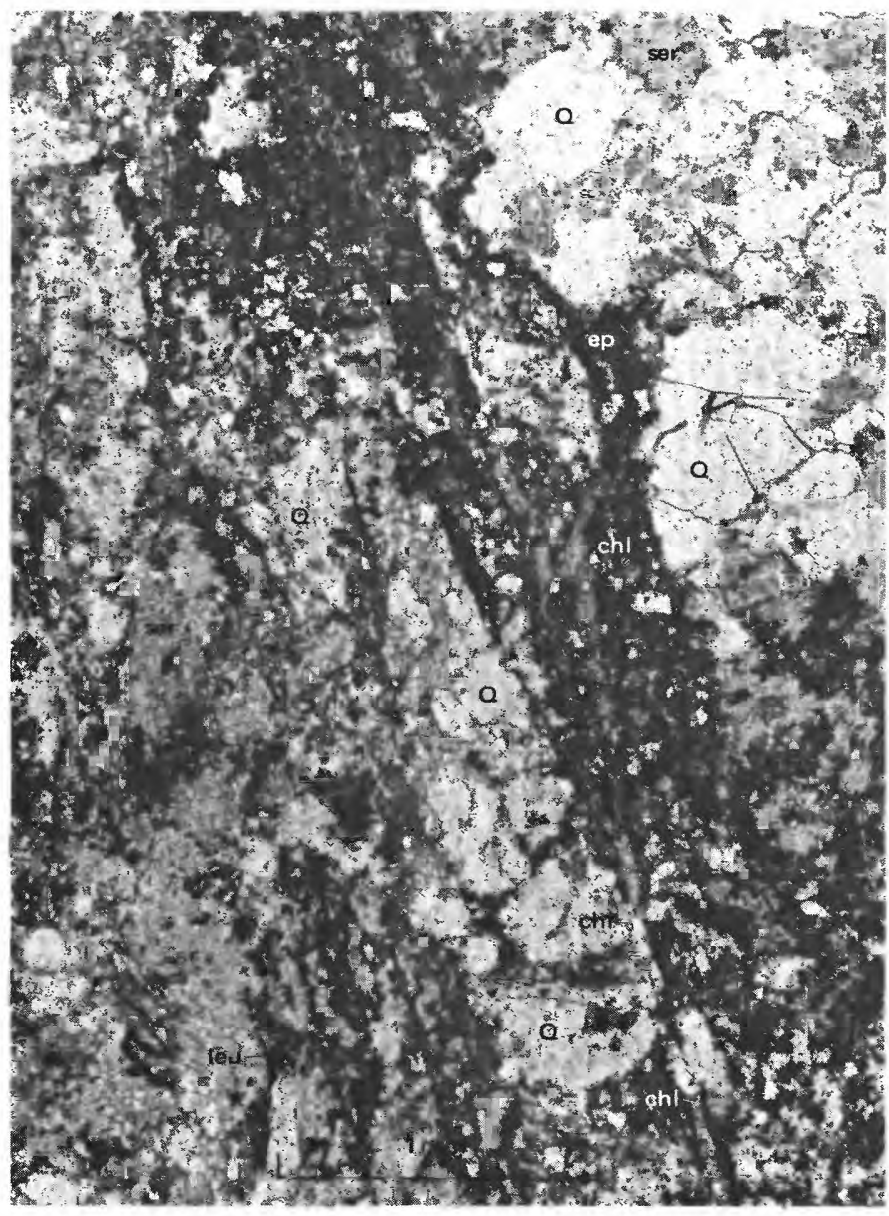

FIGURE 26.- Sheared and phyllic altered rock of the Copper Nunataks pluton: feldspar is sheared and almost totally altered to fine-grained sericite and clay (ser). Ferromagnesian minerals are totally altered to darker sericite, chlorite (chl), leucoxene (leu), and epidote (ep). Several of the shear planes are filled with chlorite. Relic quartz (Q) is sheared and broken, and it commonly has sutured boundaries. Specimen M301c. Plane light.

plagioclase contains tiny crystals of sericite and clay minerals and minor epidote and calcite (fig. 28). Biotite is slightly to largely altered to chlorite (penninite?) and is altered to less abundant epidote and leucoxene; altered minerals are concentrated along mineral cleavage planes. Hornblende is generally fresh, but it may be slightly altered to chlorite or sericite, either of which may contain minor leucoxene and hematite. Some opaque crystals are rimmed by hematite or limonite. In most rocks $\mathrm{K}$-feldspar is not altered.

X-ray studies (table 4) show that sheet silicates are significantly lower in concentration in propylitic rocks than in more intensely altered rocks. Sheet silicates consist mostly of sericite; montmorillonite and kaolinite are uncommon. Chlorite is somewhat less abundant than in argillic rocks.

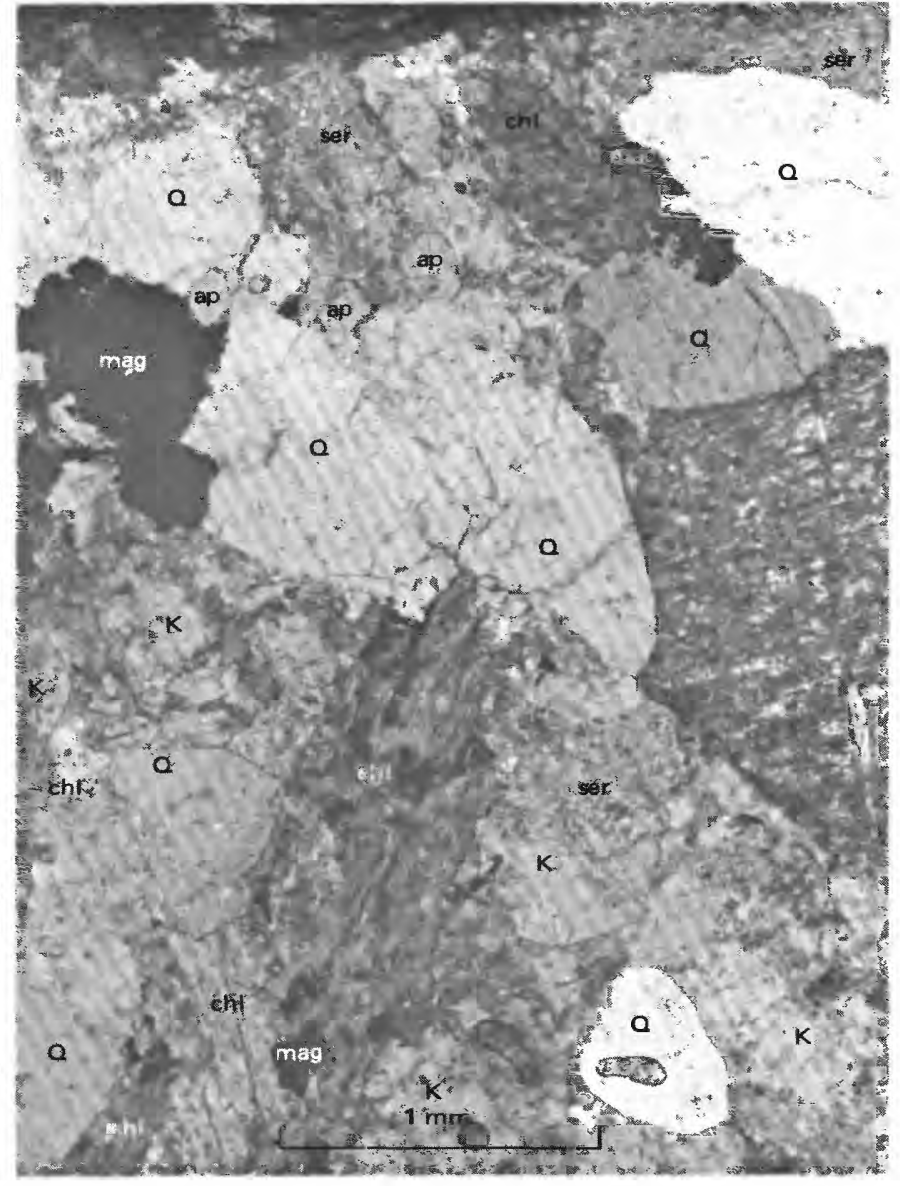

FigURE 27.-Argillic altered rock of the Copper Nunataks pluton: plagioclase is completely replaced and $\mathrm{K}$-feldspar $(\mathrm{K})$ moderately replaced by fine-grained sericite and clay (ser). Hornblende and biotite are completely replaced by chlorite (chl) and leucoxene spots. Quartz(Q) is unchanged. Magnetite (mag), laced with hematite, and apatite (ap) are present. Specimen M301i $\mathrm{i}_{2}$. Partly crossed polars.

\section{EPIDOTE ALTERATION}

Epidote occurs as a replacement mineral in the form of small irregular masses and coatings along fractures not only in the Copper Nunataks but also in plutonic rock throughout the Lassiter Coast. Its occurrence is almost universally confined to subvertical joints (see p. 20) cutting plutonic rocks and striking in the extension direction to the northwest. Crosscutting relations show that some epidote-coated joints developed following intrusion of the granodiorite pluton and prior to intrusion of the Copper Nunataks pluton, but most appear to postdate the Copper Nunataks pluton. Presumably epidote is related to very late-stage igneous solutions on a regional scale and is not confined to any alteration or mineralization event, such as those associated with the copper deposit. However, some epidote masses and coatings are abundant in and adjacent 


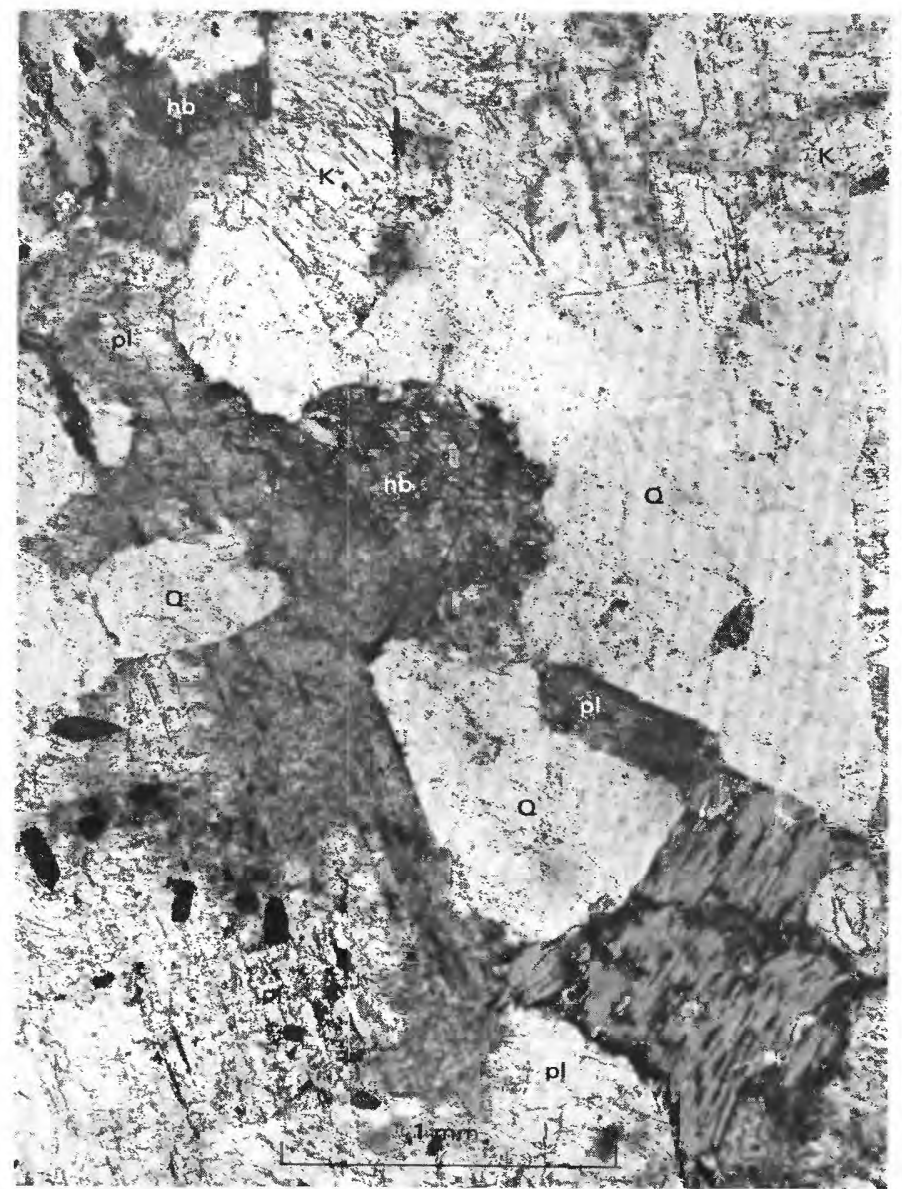

FIGURE 28.-Propylitic altered rock of the granodiorite pluton: plagioclase ( $\mathrm{pl}$ ) is lightly to moderately altered to fine-grained sericite and clay, especially along mineral cleavage, but $\mathrm{K}$-feldspar (K) is only slightly altered. Biotite is totally altered to chlorite (chl), and minor epidote (ep) is spotted with leucoxene, but hornblende (hb) is fresh. Quartz (Q) is unchanged. Specimen M301e. Plane light.

to the sheared phyllic-argillic zones and thus probably result from a low-intensity hydrothermal event.

Microscope examination of three epidotized rocks shows that most biotite and hornblende in the rock are altered to chlorite and fine- to medium-grained epidote. Plagioclase may be altered to sericite and clay minerals or it may be fresh with the exception of some contained fine epidote grains. Locally, all minerals except quartz are replaced by epidote.

\section{SILICIFICATION}

Masses of pale-green silica, as much as several cubic meters in volume, were mapped within part of a single 3-m-wide sheared phyllic-argillic zone at Nunatak B. The rock in one thin section (M309g) consists almost entirely of introduced fine-grained (mostly less than $0.4 \mathrm{~mm}$ ) quartz as anhedral to subhedral prismatic crystals (fig. 29). Some sericite, and minor hematite

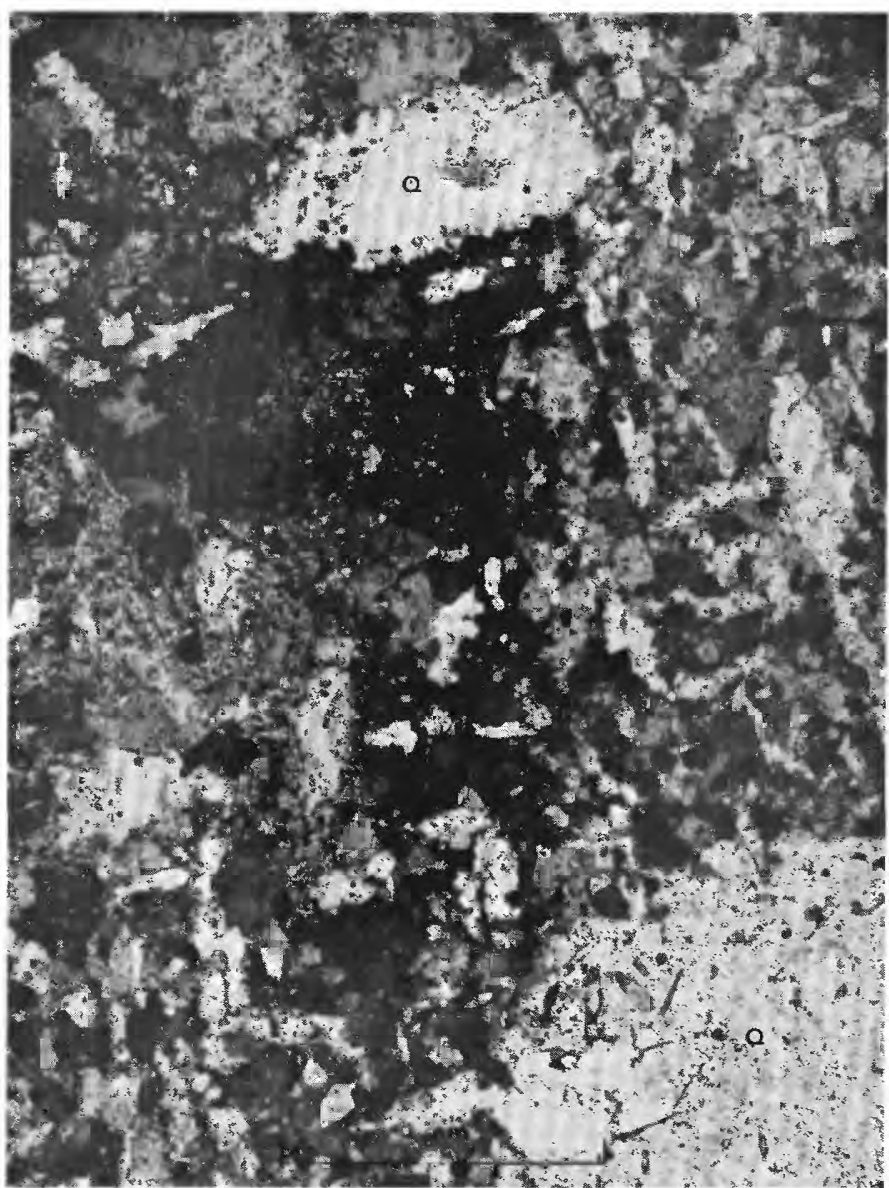

FIGURE 29.- Silicified rock from the interior of a sheared phyllicargillic zone that cuts the granodiorite pluton. Most of the rock consists of small prismatic crystals of hydrothermal quartz, grown largely along two preferred directions. Two large crystals of relic quartz $(\mathrm{Q})$ are visible, and minor sericite and clay minerals have replaced small amounts of remaining feldspar and ferromagnesian minerals. Specimen M309g. Crossed polars.

and limonite, and some original relic quartz crystals constitute the rest of the rock. Semiquantitative spectrographic analysis shows that this same specimen (table 3) is similar to other rocks from the sheared phyllic-argillic zones.

\section{MINERALIZED AND ALTERED ROCK ELSEWHERE IN THE LASSITER COAST AND SOUTHERN BLACK COAST}

Other sightings of mineralized and hydrothermally altered rock were made in the Lassiter Coast and southern Black Coast (figs. 1,2) by all members of the three field parties. No occurrences were found that were as rich as or as extensive as the Lassiter Coast copper deposit; they were noted during our reconnaissance geologic studies and were not investigated in detail. Many of these were sampled, however, and the 
TABLE 6. Semiquantitative spectrographic analyses of selected fresh, altered, and mineralized

[Sample localities shown in figure 2. Analyses of specimens B21d, B28d, P9b, S6, S31a, S33 d, S34a, S34g, S38a, S38k, S39b, S41b, S42b, S42f, S45h, S48Ala, S50g, S54c. S59de. S71caz, W39aa, W41d, and W87c3 by Jerry Matooka and E. F. Cooley; looked for but not found: As, Au, Cd, Sb, Sn. Analyses of specimens N5, Re37a, Re37b, Rol2a, Ro13abc, Ro54a, Ro75bc. Hf, In, Ir, Lu, Os, Pd, Pt, Re, Rh, Ru, Sb, Sm, Ta, Tb, Te, Th, Tl, Tm, U; value of As for specimen R054a: 1,400 ppm; value of Ge for spec. R0149b: 4 ppm; value of Ge for spec. Wi44c: $160 \mathrm{ppm}$; value of Sm for spec. N5: 5 ppm; value of Sm for spec. Ro150b: 6 ppm; value of Sn for spec. Ro150ze: 5 ppm. Analyses of remainder of specimens by J. L. Harris; less than

\begin{tabular}{|c|c|c|c|c|c|c|c|c|c|c|c|c|c|c|c|c|c|c|c|}
\hline Host & Sample & & & Weigh & $t$ perc & ent & & & & & & & rts per $m$ & illic & & & & & \\
\hline type & & Al & $\mathrm{Fe}$ & $\mathrm{Mg}$ & $\mathrm{Ca}$ & $\mathrm{Na}$ & k & $\mathrm{Ti}$ & $\mathrm{Ag}$ & B & $\mathrm{Ba}$ & $\mathrm{Be}$ & $\mathrm{Bi}$ & $\mathrm{Ce}$ & $\mathrm{Co}$ & $\mathrm{Cr}$ & $\mathrm{Cu}$ & Dy & $\mathrm{Eu}$ \\
\hline & & & & & & & & & gmatite & & & & & & & & & & \\
\hline $\begin{array}{l}\text { PG } \\
\text { PG }\end{array}$ & $\begin{array}{l}\text { Ro } 103 \mathrm{~b}----- \\
\text { S34a- }\end{array}$ & 3 & 0.3 & 0.01 & 0.3 & $>0.3$ & 2 & 0.01 & 0.1 & $<10$ & 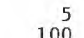 & 2 & $<1$ & $<20$ & $<1$ & 10 & 2 & 4 & $<1$ \\
\hline & & & & & & & Hyc & rother & $11 y$ alt & ered & rock & & & & & & & & \\
\hline $\mathrm{PQM}$ & Bo68c- & 11 & 3 & 0.6 & 3 & $>0.3$ & 5 & 0.2 & $<0.1$ & $<10$ & 800 & 2 & 2 & 50 & 5 & 10 & 4 & $<3$ & 1 \\
\hline PQM & Bo71b--.... & 10 & 5 & 1.8 & 6 & $>.3$ & 5 & .6 & $<.1$ & $<10$ & 700 & 4 & $<1$ & 80 & 11 & 5 & 70 & $<3$ & 2 \\
\hline $\mathrm{DL}$ & P9b---.--- & - & 3 & 1.5 & 2 & -- & -- & .1 & $\mathrm{~N}$ & 100 & 100 & N & $\mathrm{N}$ & -- & 20 & 150 & 150 & -- & -- \\
\hline PG & Ro12a-...-- & 5 & 5 & 1.8 & 4 & $>.3$ & 2 & .2 & .1 & $<10$ & 600 & 2 & $<1$ & 50 & 9 & 10 & 2 & $<3$ & 1 \\
\hline PG & Ro13abc---- & 7 & 2 & 2.0 & .3 & .03 & $>1$ & .2 & .5 & 20 & 200 & 1 & $<1$ & 40 & 3 & 10 & 7 & 7 & 2 \\
\hline PQD & Ro $75 b c$ & 7 & 6 & 4.8 & 5 & $>.3$ & 5 & 1 & $<.1$ & $<10$ & 100 & $<1$ & $<1$ & $<20$ & 40 & 30 & 90 & $<3$ & $<1$ \\
\hline PG & Ro 86 & 6 & 5 & 1.0 & 3 & $>.3$ & 1 & .1 & $<.1$ & $<10$ & 600 & $<1$ & $<1$ & $<20$ & 5 & 5 & 10 & $<3$ & $<1$ \\
\hline $\mathrm{PQD}$ & Ro113b----- & 4 & 3 & .9 & 3 & $>.3$ & 2 & .1 & .1 & $<10$ & 400 & $<1$ & $<1$ & 40 & 8 & 20 & 15 & $<3$ & $<1$ \\
\hline PG & Rol50b----- & 6 & 4 & 1.3 & 3 & $>.3$ & 3 & .4 & $<.1$ & $<10$ & 500 & 2 & $<1$ & 100 & 5 & 5 & $>10$ & $<3$ & 2 \\
\hline PG & Rol98d & 6 & 1 & .3 & 1 & $>.3$ & 4 & .2 & $<.1$ & $<10$ & 500 & 2 & $<1$ & 40 & 1 & 7 & 7 & $<3$ & 1 \\
\hline PG & Ro19 & 6 & 2 & 1.0 & 3 & $>.3$ & 3 & 1 & $<.1$ & $<10$ & 500 & $<1$ & $<1$ & & 8 & 2 & 20 & $<3$ & $<1$ \\
\hline PG & Rol99g--.-- & 4 & 2 & .7 & 1 & $>.3$ & 5 & .1 & $<.1$ & $<10$ & 300 & 1 & $<1$ & 6 & 3 & 20 & 20 & $<3$ & $<1$ \\
\hline PG & Ro215c---- & II & 3 & .6 & 4 & $>.3$ & 5 & .2 & .1 & $<10$ & 800 & 2 & $<1$ & $<20$ & 5 & 7 & 10 & 4 & $<1$ \\
\hline PG & Ro 225 & 10 & 2 & .4 & 4 & $>.3$ & 5 & .1 & $<.1$ & $<10$ & 1,200 & 3 & $<1$ & $<20$ & 1 & 10 & 120 & 4 & $<1$ \\
\hline$P G$ & Ro22 & 11 & 2 & .7 & 3 & $>.3$ & 3 & 1 & $<.1$ & $<10$ & 50 & 4 & $<1$ & 6 & 4 & & 30 & $<3$ & 1 \\
\hline PQM & Ro313a----- & 11 & 2 & .3 & 3 & $>.3$ & 5 & .2 & .3 & $<10$ & 1,000 & 2 & 6 & 60 & 4 & 1 & 70 & 5 & $<1$ \\
\hline PQM & Ro $313 \mathrm{~b}-\cdots$ & 11 & 4 & 1.3 & 4 & $>.3$ & $>1$ & .2 & $<.1$ & $<10$ & 600 & 3 & $<1$ & $<20$ & 7 & 60 & 30 & $<3$ & $<1$ \\
\hline PG & s31a- & -- & 5 & 1.5 & 2 & -- & $\ldots$ & .5 & $\mathrm{~N}$ & $\mathrm{~L}$ & 1,000 & 2 & $\mathrm{~N}$ & -- & 15 & 10 & 20 & -- & -- \\
\hline PG & S34c & -- & 10 & 1.5 & 2 & - & -- & .3 & $\mathrm{~N}$ & L & 1,500 & 2 & $\mathrm{~N}$ & -- & 15 & 10 & 15 & -- & -- \\
\hline $\mathrm{L}$ & S38k-.....- & -- & 2 & .3 & .1 & -- & -- & .2 & $\mathrm{~N}$ & 15 & 300 & $\mathrm{~L}$ & $\mathrm{~N}$ & -- & 5 & 30 & 7 & -- & -- \\
\hline DL & $\mathrm{S} 71 \mathrm{ca}_{3}-$ & -- & 5 & 1.5 & 2 & -- & -- & .2 & $\mathrm{~L}$ & $\mathrm{~L}$ & 700 & L & $\mathrm{N}$ & -- & 5 & L & 30 & -- & -- \\
\hline PG & v16b-- & 10 & 3 & .7 & 3 & $>.3$ & 5 & .2 & $<.1$ & $<10$ & 500 & 2 & $<1$ & $<20$ & 6 & 10 & 20 & 4 & 1 \\
\hline $\mathrm{L}$ & W39a & -- & 10 & 1.0 & 2 & -- & -- & .2 & $\mathrm{~N}$ & 10 & 50 & I & $\mathbb{N}$ & - & 10 & 1 & 10 & -- & -- \\
\hline $\mathrm{PQD}$ & W87 $c_{3}-$ & -- & 5 & .7 & .1 & -- & -- & .3 & & L & 1,000 & L & $\mathrm{N}$ & -- & 5 & 70 & 20 & -- & -- \\
\hline PG & W144b- & 6 & 3 & 1.0 & 2 & $>.3$ & 3 & .1 & $<.1$ & $<10$ & 400 & $<1$ & $<1$ & 50 & 7 & 20 & 10 & $<3$ & $<1$ \\
\hline PG & W1 50ze & 6 & 4 & 1.3 & 3 & $>.3$ & 3 & .4 & .1 & $<10$ & 700 & 2 & $<1$ & 100 & 6 & 5 & 20 & $<3$ & 2 \\
\hline DL & Wa $17 \mathrm{~b}_{1}-$ & 10 & 4 & .8 & 2 & $>.3$ & 4 & .2 & $<.1$ & $<10$ & 1,000 & 2 & $<1$ & 70 & 5 & 10 & 70 & $<3$ & 1 \\
\hline $\mathrm{PQM}$ & Wa37b-- & 9 & 3 & .4 & 3 & 3.3 & 5 & .1 & .1 & 18 & 400 & 2 & 4 & 40 & 4 & 7 & 100 & $<3$ & $<1$ \\
\hline & rage (a11)-- & 8 & 4 & 1.1 & 3 & $>0.3$ & 4 & 0.2 & $>0.1$ & $>6$ & 600 & $>1$ & $>0.4$ & $>40$ & 8 & 20 & $>40$ & $>1$ & $>1$ \\
\hline & & & & & & & & Barr & vanadil & & & & & & & & & & \\
\hline PG & B21d--- & $\rightarrow$ & 2 & 0.2 & 15 & -- & -- & 0.1 & $\mathrm{~N}$ & $\mathrm{~L}$ & 150 & 2 & $\mathrm{~N}$ & -- & 7 & $\mathrm{~L}$ & 7 & -- & -- \\
\hline L & S33d-- & -- & 2 & .5 & .2 & -- & -- & .5 & N & 30 & 700 & 2 & $N$ & -- & $\mathrm{L}$ & 30 & 20 & -- & -- \\
\hline $\mathrm{L}$ & S38a- & -- & .5 & .1 & .3 & -- & -- & .1 & N & $\mathrm{L}$ & 20 & $\mathrm{~N}$ & N & 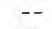 & L & I & 5 & -- & - \\
\hline DL & S39b - - & -- & 2 & .2 & $\mathrm{~L}$ & -- & -- & .1 & N & L & $\mathrm{L}$ & N & N & -- & $\mathrm{N}$ & $\mathrm{L}$ & 20 & -- & -- \\
\hline $\mathrm{L}$ & S42f-n-.... & -- & 10 & 1.5 & 2 & -- & - & .2 & .5 & L & L & L & N & -- & 10 & 20 & 70 & -- & -- \\
\hline $\mathrm{L}$ & S45h-- & -- & 5 & .1 & 10 & -- & - & .02 & $\mathrm{~N}$ & $\mathrm{~L}$ & $\mathrm{~L}$ & $\bar{I}$ & $\mathrm{~N}$ & -- & 30 & N & 5 & -- & -- \\
\hline $\mathrm{L}$ & $550 \mathrm{~g}-$ & -- & 1 & .02 & .1 & -- & -- & .1 & $\mathrm{~N}$ & L & 100 & 1 & $\mathrm{~N}$ & -- & 5 & 20 & 100 & -- & -- \\
\hline L & S59de-- & -- & 7 & .3 & 1 & -- & -- & .2 & 1.5 & 10 & 300 & 1 & N & -- & 15 & 30 & 20 & -- & -- \\
\hline & rage (a11)-- & -- & 4 & 0.4 & 4 & -- & -- & 0.2 & $>0.3$ & $>5$ & $>160$ & $>1$ & $\mathrm{~N}$ & -- & $>8$ & $>13$ & 30 & -- & -- \\
\hline & & & & & & & & Mine & lized $\mathrm{r}$ & ock & & & & & & & & & \\
\hline $\mathrm{v}$ & B28d--- & -- & 1 & 0.1 & 0.2 & -- & -- & 0.1 & 0.5 & $\mathrm{~L}$ & 1,500 & $\mathrm{~N}$ & $\mathrm{~N}$ & -- & 5 & 10 & 5 & -- & -- \\
\hline PG & Bo $44 \mathrm{e}-$ & 3 & 5 & .3 & & $\mathrm{H}$ & $>1$ & 1 & & 14 & 100 & 1 & $<1$ & 60 & 3 & 8 & 200 & $<3$ & $<1$ \\
\hline $\mathrm{PQM}$ & Bo68b- - & 8 & 1 & 1 & 1 & 3 & 7 & .1 & 1.2 & $<10$ & 1,10 & 2 & 11 & 30 & 5 & 2 & 50 & $<3$ & $<1$ \\
\hline$P Q M$ & Bo $71 \mathrm{c}--$ & 7 & .5 & .1 & 1 & 4 & 6 & .1 & $<.1$ & $<10$ & 400 & 1 & $<1$ & $<20$ & $<1$ & 7 & $<1$ & $<3$ & $<1$ \\
\hline$P Q M$ & Ka316-4 & 3 & 7 & 2.1 & 1 & .02 & 1 & .04 & $<.1$ & $<10$ & 50 & 2 & $<1$ & $<20$ & 20 & 2 & 100 & $<3$ & $<\overline{1}$ \\
\hline L & Ke7g - - & 4 & 1 & .6 & .4 & .2 & $>1$ & .2 & $<.1$ & 17 & 300 & 2 & $<1$ & 20 & 3 & 8 & 300 & 3 & $<1$ \\
\hline PD & Ke4lde- & 8 & 8 & 4.2 & $6^{\circ}$ & $>.3$ & $>1$ & .5 & $<.1$ & $<10$ & 400 & $<1$ & $<1$ & $<20$ & 30 & 20 & 100 & $<3$ & 1 \\
\hline PD & $\mathrm{Ke} 41 \mathrm{fg}-$ & 9 & 6 & 3.2 & 8 & $>$ & $>1$ & .3 & & $<1$ & 2 & $<1$ & 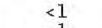 & & & & 800 & $<3$ & $\frac{1}{2}$ \\
\hline PG & N5--.- & 7 & 4 & 1.0 & 1 & $>$ & 4 & .5 & $<.1$ & 2 & 7 & 2 & $<1$ & & & & $>10$ & 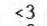 & \\
\hline$P Q D$ & Re37a-..... & 4 & 4 & .9 & 3 & $>$. & 2 & .2 & $<.1$ & $<10$ & 400 & $<1$ & $<1$ & $<2$ & 20 & 30 & 5 & $<3$ & $<1$ \\
\hline $\mathrm{L}$ & Ro54a-- & . & 3 & .01 & $<.1 \quad r \quad r$ & $>.3$ & .1 & .03 & 7 & $<10$ & 3 & $<1$ & $<1$ & $<20$ & 6 & 5 & 300 & $<3$ & $<1$ \\
\hline PD & Ro $241 \mathrm{~b}$ & $9^{\circ}$ & 5 & 2.2 & 7 & 3 & $2^{\circ}$ & .2 & $<.1$ & $<10$ & 30 & $<1$ & $<1$ & $<20$ & 30 & 8 & 100 & $<3$ & $<1$ \\
\hline PG & Ro25 & 5 & 3 & .6 & 1 & $>.3$ & 5 & .1 & $<.1$ & $<1$ & 40 & 1 & $<$ & $<2$ & 7 & & 200 & $<3$ & $<1$ \\
\hline $\mathrm{L}_{\mathrm{L}}$ & Ro $256 c-$ & 7 & 4 & 1.0 & 1 & $>$. & $>1$ & .2 & $<.1$ & 3 & 30 & 2 & $<1$ & 8 & 10 & 3 & 70 & $<3$ & 1 \\
\hline DL & Ro $315 \mathrm{~d}-\ldots$ & 11 & 5 & 1.8 & 5 & $>.3$ & 3 & 3 & $<.1$ & $<1$ & 600 & 2 & $<1$ & 60 & 10 & 3 & 70 & $<3$ & 1 \\
\hline $\mathrm{L}$ & Ro315h--.-- & & 10 & .03 & & & $<. I$ & & 1.2 & $<10$ & $<15$ & $<1$ & $<1$ & $<20$ & 60 & 5 & 100 & $<3$ & $<1$ \\
\hline $\mathrm{PQD}$ & S6- & -- & 2 & .3 & 2 & -- & -- & .2 & 2 & $\mathrm{~L}$ & 100 & 2 & $\mathrm{~N}$ & - & 70 & 50 & 1,000 & -- & -- \\
\hline $\mathrm{PQD}$ & S54c- & -- & 2 & .03 & .2 & - & -- & .01 & $\mathrm{~N}$ & $\mathrm{~L}$ & 200 & $\mathrm{~N}$ & $\mathrm{~N}$ & -- & 5 & $\mathrm{~L}$ & 100 & $\cdots$ & -- \\
\hline $\mathrm{PQM}^{-1}$ & v32c- - & I & 3 & .5 & .1 & .2 & & .004 & $<1$ & $<10$ & 10 & $<1$ & $<1$ & $<20$ & 10 & 1 & 500 & $<3$ & $<1$ \\
\hline DL & W41d-. & -- & 5 & 3.0 & 5 & & $\cdots$ & & $\mathrm{N}$ & & L & $\mathrm{N}$ & $\mathrm{N}$ & & 50 & 1,500 & 150 & -- & -- \\
\hline PD & W113de--.-- & 1 & 10 & 6.2 & 6 & .1 & .2 & .3 & 1.8 & $<10$ & 20 & $<1$ & $<1$ & $<20$ & & & 800 & $<3$ & $<1$ \\
\hline $\mathrm{PQD}$ & W139h- & .3 & 6 & .03 & .1 & .1 & 1 & .02 & $<1$ & $<10$ & 50 & $<1$ & $<1$ & $<20$ & 2 & $<1$ & & $<3$ & $<1$ \\
\hline PG & W144c---.-- & 5 & 7 & 1.7 & 4 & $>.3$ & 3 & .1 & 5 & $<10$ & 300 & $<1$ & $<1$ & $<20$ & 30 & 20 & $>1,000$ & $<3$ & $<1$ \\
\hline PG & & 1 & 2 & 3 & 1 & .04 & 1 & .1 & .1 & 33 & 70 & $<1$ & $<1$ & $<2$ & 5 & 2 & & $<3$ & $<1$ \\
\hline $\mathrm{PQM}$ & Wa21- & 6 & 5 & 1.5 & 2 & $>.3$ & 3 & .1 & $>10$ & $<10$ & 400 & $<1$ & 1,200 & $<20$ & 30 & 6 & 7,000 & $<3$ & $<1$ \\
\hline & rage (all)-- & 5 & 5 & 1.3 & 2 & -- & -. & 0.2 & $>1.2$ & $>5$ & $>300$ & $>1$ & $>50$ & $>20$ & $>20$ & 70 & $>500$ & $<3$ & $>0.3$ \\
\hline & & & & & & & & & ote rocl & & & & & & & & & & \\
\hline PQM & Bo64b- & 13 & 5 & 2.2 & 7 & $>0.3$ & 1 & 0.4 & $<0.1$ & $<10$ & 100 & 2 & $<1$ & 80 & & 30 & 10 & 7 & 2 \\
\hline PQD & $\operatorname{Re} 37 \mathrm{~b}--$ & 6 & 4 & 1.4 & 4 & $>.3$ & 4 & .2 & $<.1$ & $<1$ & 500 & $<1$ & $<1$ & $<2$ & 2 & 8 & 5 & $<3$ & $<1$ \\
\hline PG & Rol49b- & 6 & 5 & .6 & 8 & $>.3$ & 2 & .1 & .5 & $<10$ & 400 & I & $<1$ & 60 & 1 & 3 & 300 & $<3$ & 1 \\
\hline PG & S4lb- & -- & .5 & & . & & & & & $\mathrm{L}$ & & $\mathrm{N}$ & $\mathrm{N}$ & -- & $\mathrm{N}$ & $\mathrm{N}$ & 5 & -- & -- \\
\hline PG & S48Ala-..-- & -- & 2 & 1.0 & $I^{\circ}$ & -- & $\ldots$ & .2 & $\mathrm{~N}$ & $\mathrm{~L}$ & 500 & $\mathrm{~N}$ & $\mathrm{~N}$ & - & 7 & 10 & 30 & -- & -- \\
\hline $\mathrm{PQD}$ & Wl $39 \mathrm{~d}_{2}-$ & 5 & 3 & 1.0 & 3 & $>.3$ & 1 & 1 & $<.1$ & $<10$ & 300 & $<1$ & $<1$ & 40 & 7 & 8 & 20 & $<3$ & $<1$ \\
\hline & rage (all)-- & 7 & 3 & 1.1 & 4 & $>0.3$ & 2 & 0.2 & 0.1 & $<10$ & 300 & $>1$ & $<1$ & $>40$ & $>7$ & I & 60 & $>2$ & 1 \\
\hline
\end{tabular}


rock from scattered locations elsewhere in the Lassiter Coast and southern Black Coast

lower limits: As, Au, Cd, Cs, Er, Ge, Hf, Hg. In, Ir, Li, Lu, Os, Pd, Pt. Rb, Re, Rh, Rn, Sb, Sm, Ta, Tb, Te. Th, T1, Tm, U; value of Cd for spec. Bo44e: 15 ppm; value of Er for spec. Ke7g: 3 ppm; value of Ge for spec. Bo71b: 2 ppm; value of Li for spec. Ka316-4: 45 ppm: value of Li for spec. V32c: 38 ppm. G, greater than 10 percent; H, interference; leaders (-), not $V$, volcanic rocks: DL, dike cutting Latady Formation; PD, plutonic rocks of diorite com position; PQD, plutonic rock of quartz diorite composition; PG, plutonic rock of granodiorite composition; PQM, plutonic rock of quartz monzonite composition]

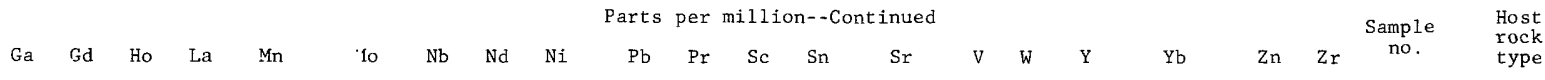

$$
\begin{aligned}
& \text { Pegmatite--Continued }
\end{aligned}
$$

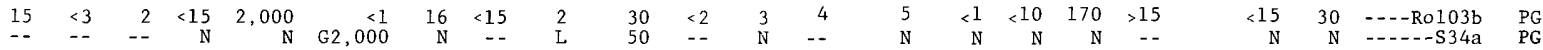

$$
\begin{aligned}
& \text { Hydrothermally altered rock--Continued } \\
& \begin{array}{rrrrr}
18 & 3 & <1 & 30 & 500 \\
23 & 4 & <1 & 30 & 3,000 \\
-17 & -1 & -2 & N & 300 \\
15 & 7 & 1 & 30 & 1,300 \\
15 & 7 & 1 & 600
\end{array} \\
& \begin{array}{rrrrr}
3 & 7 & <1 & <15 & 1,000 \\
13 & 4 & 1 & <15 & 1,100 \\
9 & <3 & <1 & 20 & 1,000 \\
18 & 13 & 3 & 50 & 900
\end{array} \\
& \begin{array}{rrrrr}
19 & 6 & <1 & 30 & 400 \\
9 & 4 & <1 & 15 & 700 \\
9 & <3 & <1 & 40 & 400
\end{array} \\
& \begin{array}{rrrrrrrrr}
17 & <3 & <1 & <15 & 400 & <1 & 3 & 40 \\
15 & & 4 & 5 & <15
\end{array} \\
& \begin{array}{rrrrr}
23 & <3 & 1 & <15 & 600 \\
11 & <3 & <1 & 30 & 500
\end{array} \\
& \begin{array}{rrrrr}
11 & <3 & <1 & 30 & 500 \\
21 & 4 & 2 & 30 & 600 \\
21 & 4 & 2 & 50 & 1,100
\end{array} \\
& \begin{array}{lllll}
-- & -- & -- & 30 & 1,500 \\
-- & -- & -- & 30 & 1,500
\end{array} \\
& \begin{array}{rrrrr}
-- & -- & -- & 30 & 1,500 \\
-- & -- & -- & 20 & 200 \\
\hline & - & - & &
\end{array} \\
& \begin{array}{rrrrr}
14 & <3 & <1 & <15 & 700 \\
-- & - & -- & N & 1,500
\end{array} \\
& \begin{array}{rrrrr}
-- & -- & - & \mathbb{N} & 1,500 \\
-\overline{9} & -\overline{<} & -- & 50 & 300 \\
<1 & 20 & 700
\end{array} \\
& \begin{array}{lllll}
17 & 12 & 23 & 50 & 1,000 \\
15 & <3 & <1 & 40 & 1,000
\end{array} \\
& \begin{array}{lllll}
15 & <3 & <1 & 40 & 1,000 \\
18 & <3 & <1 & 20 & 1,500
\end{array} \\
& 15>4>1 \quad>30 \quad 1,000 \\
& \begin{array}{rrrrr}
- & -- & -- & 50 & 200 \\
-- & -- & -- & 50 & 300 \\
-- & -- & -- & \mathrm{N} & 70 \\
- & -- & \mathrm{N} & 100
\end{array} \\
& \begin{array}{lllll}
-- & - & - & 20 & 1,500
\end{array} \\
& \begin{array}{rrrrr}
-- & -- & -- & \mathrm{N} & 2,000 \\
-- & -- & -- & \mathrm{N} & 700 \\
- & - & - & 20 & 1,000
\end{array} \\
& \begin{array}{llllll}
- & -- & - & >20 & 700
\end{array} \\
& \begin{array}{rrrr}
3 & 4 & <15 & \\
5 & 5 & 30 & \\
\mathrm{~N} & \mathrm{~N} & <-15 & 30 \\
2 & <2 & <15 & \\
50 & 4 & 20 &
\end{array} \\
& \begin{array}{rrrrrrrrr}
40 & 5 & 5 & <3 & 500 & 70 & <10 & 20 & 2 \\
10 & 8 & 15 & 8 & 400 & 200 & <10 & 50 & 6 \\
\mathrm{~N} & -6 & 15 & -- & \mathrm{N} & 500 & \mathrm{~N} & \mathrm{~L} & - \\
10 & 6 & 10 & <3 & 800 & 100 & <10 & 20 & 5 \\
30 & 4 & 7 & <3 & 30 & 100 & <10 & 60 & 4
\end{array} \\
& \begin{array}{rrrr}
2 & <2 & 20 & 20 \\
1 & <2 & 30 & 3 \\
1 & 2 & 20 & \\
7 & 9 & 50 & 2
\end{array} \\
& \begin{array}{rrrrrrrrr}
3 & \mathrm{H} & 20 & <3 & 400 & 100 & <10 & 7 & 1 \\
3 & 5 & 7 & <3 & 600 & 70 & <10 & 15 & 2 \\
3 & 6 & 5 & 3 & 200 & 50 & <10 & 10 & 1 \\
10 & 13 & 10 & 4 & 700 & 150 & <10 & 70 & 7
\end{array} \\
& \begin{array}{rrrrr}
10 & 5 & 5 & <3 & 200 \\
10 & 5 & 10 & <3 & 300 \\
3 & 6 & 7 & <3 & 200 \\
20 & 4 & 7 & <3 & 500
\end{array} \\
& \begin{array}{ll}
30 & <10 \\
70 & <10 \\
70 & <10
\end{array} \\
& \begin{array}{rrrrrrrr}
30 & <2 & 7 & 3 & 600 & 30 & <10 & 20 \\
30 & 5 & 10 & <3 & 400 & 50 & <10 & 30
\end{array} \\
& \begin{array}{rrrr}
8 & 6 & <15 & 2 \\
2 & 5 & 30 & 6 \\
3 & 8 & 20 & 2 \\
3 & 5 & <15 & 11
\end{array} \\
& \begin{array}{rrrr}
\mathrm{N} & 10 & - & \mathrm{L} \\
10 & 10 & - & \mathrm{L} \\
\mathrm{N} & \mathrm{N} & -- & \mathrm{L} \\
\mathrm{N} & \mathrm{N} & -- & \mathrm{L}
\end{array} \\
& \begin{array}{rrrrr}
40 & 6 & 5 & 4 & 600 \\
30 & <2 & 7 & <1 & 500
\end{array} \\
& \begin{array}{ll}
30 & <10 \\
70 & <10
\end{array} \\
& \begin{array}{rrrrr}
20 & -- & 20 & -- & 500 \\
30 & -- & 15 & -- & 500 \\
30 & -- & 7 & -- & \mathbb{N} \\
10 & -- & 7 & -- & 300
\end{array} \\
& \begin{array}{rrr}
7 & <15 & 3 \\
\mathbb{N} & -- & 30 \\
10 & -- & 20 \\
<2 & 20 & 10
\end{array} \\
& \begin{array}{rrrrr}
30 & <2 & 10 & <1 & 400 \\
30 & -- & 7 & -- & 200 \\
10 & -- & 15 & -- & 200 \\
5 & 4 & 7 & <3 & 200
\end{array} \\
& \begin{array}{rrrr}
2 & 7 & 70 & 2 \\
10 & 4 & 20 & 5 \\
3 & 6 & 15 & 3
\end{array} \\
& \begin{array}{rrrrr}
10 & 10 & 15 & 6 & 700 \\
15 & 7 & 7 & <3 & 600 \\
20 & 4 & 4 & <3 & 150
\end{array} \\
& >17>5 \quad 10>1 \quad>400
\end{aligned}
$$

\begin{tabular}{|c|c|c|c|c|c|c|c|c|c|c|c|c|c|c|}
\hline $\begin{array}{r}\mathrm{N} \\
15 \\
\mathrm{~N} \\
\mathrm{~N}\end{array}$ & $\begin{array}{l}= \\
=- \\
=-\end{array}$ & $\begin{array}{l}\mathrm{L} \\
5 \\
\mathrm{~L} \\
\mathrm{~N}\end{array}$ & $\begin{array}{r}20 \\
30 \\
\mathrm{~N} \\
\mathrm{~N}\end{array}$ & $\begin{array}{l}-- \\
=- \\
--\end{array}$ & $\begin{array}{r}5 \\
15 \\
N \\
5\end{array}$ & $\begin{array}{l}= \\
=- \\
--\end{array}$ & $\begin{array}{r}\mathrm{N} \\
100 \\
\mathrm{~N} \\
\mathrm{~N}\end{array}$ & $\begin{array}{r}70 \\
150 \\
10 \\
10\end{array}$ & $\begin{array}{l}\mathrm{N} \\
\mathrm{N} \\
\mathrm{N} \\
\mathrm{N}\end{array}$ & $\begin{array}{r}15 \\
30 \\
\mathrm{~L} \\
30\end{array}$ & $\begin{array}{l}-- \\
-- \\
--\end{array}$ & $\begin{array}{l}\mathrm{N} \\
\mathrm{N} \\
\mathrm{N} \\
\mathrm{N}\end{array}$ & $\begin{array}{r}50 \\
200 \\
70 \\
15\end{array}$ & 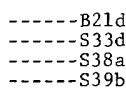 \\
\hline $\begin{array}{l}\text { N } \\
\text { N } \\
\text { N } \\
\text { L }\end{array}$ & $\begin{array}{l}-: \\
-z \\
-z\end{array}$ & $\begin{array}{r}15 \\
70 \\
7 \\
50\end{array}$ & $\begin{array}{l}\text { N } \\
50 \\
15 \\
50\end{array}$ & $\begin{array}{l}-- \\
-- \\
--\end{array}$ & $\begin{array}{r}15 \\
5 \\
5 \\
10\end{array}$ & $\begin{array}{l}-- \\
-- \\
--\end{array}$ & $\begin{array}{r}300 \\
300 \\
\mathrm{~N} \\
\mathrm{~N}\end{array}$ & $\begin{array}{r}50 \\
\mathrm{~N} \\
30 \\
70\end{array}$ & $\begin{array}{l}\mathrm{N} \\
\mathrm{L} \\
\mathrm{N} \\
\mathrm{N}\end{array}$ & $\begin{array}{l}50 \\
15 \\
20 \\
20\end{array}$ & $\begin{array}{l}-: \\
-: \\
--\end{array}$ & $\begin{array}{l}\mathrm{N} \\
\mathrm{N} \\
\mathrm{N} \\
\mathrm{L}\end{array}$ & $\begin{array}{r}300 \\
20 \\
70 \\
200\end{array}$ & $\begin{array}{l}----S 42 \mathrm{f} \\
---S 45 h \\
-\cdots--S 50 \mathrm{de}\end{array}$ \\
\hline$>2$ & -- & $>2$ & $>2$ & -- & $>$ & -- & $>90$ & $>50$ & $\mathrm{~N}$ & $>25$ & -. & $\mathrm{N}$ & 100 & jerage \\
\hline
\end{tabular}
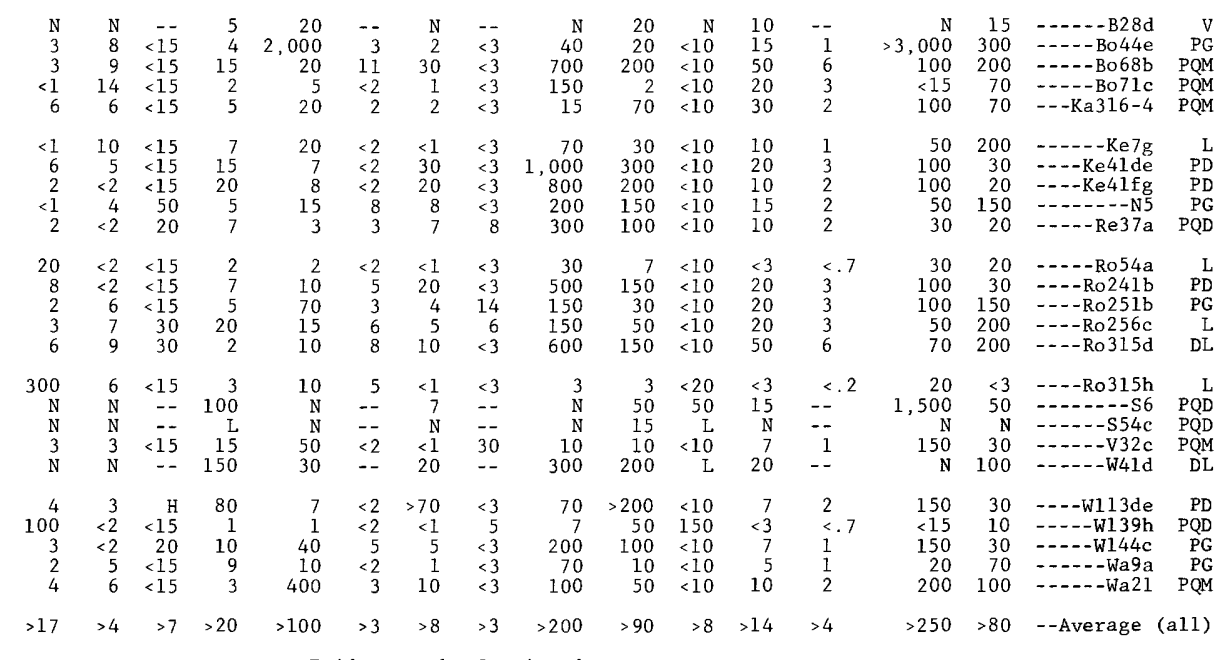
results of about 70 semiquantitative spectrographic analyses of these specimens (table 6 ) reveals that, in overall families of trace elements, the mineralized rock is similar to that of the Lassiter Coast copper deposit, and that the hydrothermally altered rock is similar to that of the sheared phyllic-argillic zones. The main element additions consisted of $\mathrm{Cu}$ and less abundant $\mathrm{Fe}, \mathrm{Zn}, \mathrm{Mo}, \mathrm{Pb}$, and perhaps Ag. Essentially all occurrences were within or immediately adjacent to stocks or batholiths that are probably similar in age (Mehnert and others, 1975; Rowley and others, 1976) to the plutons at the copper deposit. The number of occurrences appears to increase somewhat to the north, paralleling the northward increase in the proportion of igneous rock to metamorphosed sedimentary and volcanic rock.

Quartz veins are a major locus of mineralized rock and are abundant at many outcrops in the Lassiter Coast. The results of semiquantitative spectrographic analyses of numerous veins reveal two categories of quartz veins. Those veins that occur in sedimentary rocks far from igneous contacts do not contain sulfide minerals and almost invariably do not exhibit any high values of minor elements. They undoubtedly are veins related to metamorphic and tectonic processes during deformation of the sedimentary and volcanic rock; many of the veins do not have roots and are metamorphic quartz segregations. Quartz veins in or adjacent to igneous rocks, on the other hand, may contain macroscopic sulfide minerals and most exhibit an addition of some minor elements.

Semiquantitative spectrographic analyses of the sulfide-bearing quartz veins reveal moderately high $\mathrm{Cu}$ from the eastern Werner Mountains (specimen Ro256c), southern Playfair Mountains ( $\mathrm{Ke} 7 \mathrm{~g}$ ), and the western RARE Range (S54c). High to moderate values of $\mathrm{Cu}$ and $\mathrm{Zn}$ occur in unnamed mountains of the southern Black Coast (Ka316-4), Werner Mountains (Ro251b), Ferguson Nunataks (V32c), and chalcopyrite-bearing rock from the northern Latady Mountains (S6). Pyrite-bearing rock (Wa9a) from the eastern Werner Mountains and rock (Ro54a) from the eastern Guettard Range show anomalous As and moderate $\mathrm{Cu}$. High $\mathrm{Mo}$ and moderate $\mathrm{Cu}$ characterize pyritebearing rock in the southern Black Coast (Ro315h), and high Mo and $\mathrm{W}$ occur in chalcopyrite-molybdenite bearing rock from the western RARE Range (W139h). High $\mathrm{Zn}$ and $\mathrm{Pb}$ and moderate $\mathrm{Cu}$ values were determined for altered and silicified rock in the western Werner Mountains (Bo44e). Sulfides also occur as pods or disseminated crystals in localized areas. A zone containing pyrite, chalcopyrite, malachite-chrysocolla(?), and azurite, and containing high values of $\mathrm{Cu}, \mathrm{Pb}, \mathrm{Zn}$, $\mathrm{Bi}$, and apparently Ag occurs in plutonic rock (Wa21) in the northern Dana Mountains. A possible malachite stain was noted at Mount Poster (B28d) west of the Latady Mountains. Several pyrite zones were found in plutonic rock (S53) in the northern Latady Mountains. Veins and disseminated crystals of pyrite in silicic porphyry dikes occur at outcrops in the southern Black Coast (Ro315d) and Scaife Mountains (W41d); malachite-chrysocolla(?) stains occur at the contact of a silicic porphyry dike cutting plutonic rocks in the northern Dana Mountains (Wa20). Molybdenite was observed in pegmatites in the eastern Hutton Mountains (Ro168e) and Latady Mountains (S34a). Malachite-chrysocolla(?), occasionally accompanied by chalcopyrite and quartz veins, commonly occurs in more mafic (mostly pyroxene and hornblende diorite or gabbro) plutonic contact phases in the southeastern Dana Mountains (Ro303), Werner Mountains (Ke37g, Ke41de, Ke41fg, Ro24lb), Watson Peaks (V31e), Rivera Peaks (Ke20gk), southwestern Playfair Mountains (F1, V3, V5), and Guettard Range (W113de); semiquantitative spectrographic analyses of samples for some of these outcrops reveal high to moderate values of $\mathrm{Cu}, \mathrm{Zn}$, and for some rocks $\mathrm{Pb}$.

Hydrothermally altered igneous rock of argillic and phyllic facies was sampled in numerous areas in the Lassiter Coast and southern Black Coast. Such altered rock commonly occurs at igneous contacts, as in the southern Dana Mountains (Ro225a), northern Hutton Mountains (Ro198de), Guettard Range (Ro12a, Ro13abc), RARE Range (Ro75bc, Ro86a), and Latady Mountains (S34d, S38k, W87c). Some silicic dike rocks are intensely hydrothermally altered, as in the southeastern Werner Mountains (Wa17b $b_{1}$, northeastern Latady Mountains (P9b), and western Scaife Mountains (S71ca3). Poorly defined areas of hydrothermally altered rock within plutons were observed in the southern Black Coast (Bo71b), southwestern Dana Mountains (Ro228b), southern Hutton Mountains (Ro150b, W150ze), and Latady Mountains (S31a). In some places the altered rock follows narrow linear zones as much as several meters in width that cut plutonic rocks. These are similar in appearance and petrology to the sheared phyllic-argillic zones of the copper deposit; this similarity and their linearity indicate that they also were the sites of fracturing and perhaps of shearing. Such sheared phyllic-argillic zones were mapped in the southern Black Coast (Bo68c, Ro313a, Ro313b, Wa37b), Rivera Peaks (Ro215c), northern Playfair Mountains (V16b), and northwestern RARE Range (Ro113b, Ro199bc, Ro199g, W144b). Ore minerals occur adjacent to the zones at two of these locations; semiquantitative spectrographic analyses prove that samples containing pyrite (Bo68b) and pyrite and malachite-chrysocolla(?) (W144c) have been enriched in $\mathrm{Cu}$ and $\mathrm{Zn}$. 


\section{CONCLUSIONS}

The Lassiter Coast copper deposit evolved during a complex series of igneous and structural events. The Late Cretaceous history in the immediate vicinity of the deposit consists of two essentially identical broad episodes, both of which were initiated by batholith intrusion of granodiorite and by stock intrusion of quartz monzonite (Copper Nunataks pluton) into a terrane of tightly folded Upper Jurassic eugeosynclinal sedimentary and volcanic rocks. Each of these plutonic events was followed by intrusion of hypabyssal, mostly porphyritic, more mafic dikes, and each broad episode was terminated by shear-fracturing, hydrothermal alteration, and weak mineralization. The major copper mineralization occurred during the younger quartz monzonite episode. At this time phyllic and argillic altered rock was formed along linear sheared zones between which is a broad propylitic zone. Mineralized rock occurs over a broad area and is not confined to the sheared phyllic-argillic zones; however, it is most intensely developed in the wallrock where the zones are most abundant.

The Lassiter Coast copper deposit bears many similarities to the typical porphyry copper deposit described by Lowell and Guilbert (1970). The associated and slightly older porphyry dikes are similar in petrology, chemistry, and age to those that preceded mineralization in the typical porphyry deposits of the circum-Pacific province. The alteration and mineralization assemblages also have many similarities in petrology and chemistry. Probably the chief departures of the Lassiter Coast deposit from the typical commercial porphyry deposit are the coarseness and relatively low grade of the mineralized rock and the linear pattern of altered and mineralized rock instead of the typical concentric zones of altered and mineralized rock.

Using the porphyry model (Lowell and Guilbert, 1970; Sillitoe, 1973) we can speculate on the location of a possible zone of higher grade. The coarseness of the quartz veins and disseminated sulfides, the presence of magnetite, and the lack of a significant potassic alteration zone suggest a site marginal to a higher grade deposit. Reconnaissance geologic mapping of numerous plutons elsewhere in the Lassiter Coast area suggests that it is unlikely that the roofs of the plutons in the area of the copper deposit were more than $1,000 \mathrm{~m}$ above the present peaks of the nunataks. This may suggest that erosion has not removed any significant ore deposit. Richer deposits may lie below the present erosion surface at the Copper Nunataks site or they may occur adjacent to the copper deposit described.

The Lassiter Coast is part of the circum-Pacific igneous-tectonic province, which contains most of the world's economic porphyry deposits. The existence of the Lassiter Coast copper deposit and the numerous other occurrences of similar metallized and hydrothermally altered rock nearby prove that the southern Antarctic Peninsula locally contains anomalous copper concentrations. And from what can be determined by a review of the literature of other types of mineralized rock farther north (Rowley and others, 1975), we conclude that the Antarctic Peninsula is a copper province and that at least locally there are affinities with the porphyry type of copper deposit in this province. A tie between the copper provinces of Antarctica and South America has been proposed by Sillitoe (1972, p. 193); this proposal is not surprising in light of the geologic similarities already mentioned. The discovery of the Lassiter Coast copper deposit provides the first geologic data for completing the southern extension of the circum-Pacific copper province. While this deposit has very low economic potential in the foreseeable future, the presence of the Lassiter Coast deposit suggests that economic deposits might be present in the Antarctic Peninsula.

\section{REFERENCES CITED}

Adie, R. J., 1954, The basement complex; early Paleozoic plutonic and volcanic rocks, [pt.] 1 of The petrology of Graham Land: Falkland Islands Dependencies Survey Sci. Rept. 11, 22 p.

1955, The Andean granite-gabbro intrusive suite, [Pt.] 2, of The petrology of Graham Land: Falkland Islands Dependencies Survey Sci. Rept. 12, 39 p.

1957, Metamorphic rocks of the Trinity Peninsula Series, [Pt.] 3 of The petrology of Graham Land: Falkland Islands Dependencies Survey Sci. Rept. 20, 26 p.

1964, Geologic history, in Priestly, R. E., Adie, R. J., and Robin, G. D., eds., Antarctic research-A review of British scientific achievements in Antarctica: London, Butterworths, p. 118-162.

1969, Geologic map of Antarctica, in Bushnell, V. C., and Craddock, Campbell, eds., Geologic maps of Antarctica: Am. Geog. Soc. Antarctic Map Folio Ser. 12, pls. 1, 2.

Banks, N. G., 1974, Distribution of copper in biotite and biotite alteration products in intrusive rocks near two Arizona porphyry copper deposits: U.S. Geol. Survey Jour. Research, v. 2, no. 2, p. 195-211.

Bateman, P. C., 1961, Granitic formations in the east-central Sierra Nevada near Bishop, California: Geol. Soc. America Bull., v. 72, no. 10 , p. 1521-1538.

Bibby, J. S., 1966, The stratigraphy of part of northeast Graham Land and the James Ross Island Group: British Antarctic Survey Sci. Repts. 53, 37 p.

Boyer, S. J., 1975, Chemical weathering of rocks on the Lassiter Coast, Antarctic Peninsula, Antarctica: New Zealand Jour. Geology and Geophysics, v. 18, no. 4, p. 623-628.

Bradshaw, J. D., and Andrews, P. B., 1973, Geotectonics and the New Zealand geosyncline: Nature; Phys. Sci., v. 241, p. 14-16.

Craddock, Campbell, 1970a, Tectonic map of Antarctica, in Bushnell, V. C., and Craddock, Campbell, eds., Geologic maps of Antarctica: Am. Geog. Soc. Antarctic Map Folio Ser. 12, pl. 21. 1970b, Map of Gondwanaland, in Bushnell, V. C., and Craddock, Campbell, eds., Geologic maps of Antarctica: Am. Geog. Soc. Antarctic Map Folio Ser. 12, pl. 23. 
1972, Antarctic tectonics, in Adie, R. J., ed., Antarctic geology and geophysics, Symposium on Antarctic geology and solid earth geophysics, Oslo, August 6-15, 1970: Internat. Union Geol Sci., ser. B, no. 1 , p. $449-455$.

Dalziel, I. W. D., and Elliot, D. H., 1973, The Scotia Arc and Antarctic margin, in Nairn, A. E. M., and Stehli, F. G., eds., The South Atlantic, Volume 1 of The ocean basins and margins: New York, Plenum Press, p. 171-246.

Elliot, D. H., 1972, Aspects of Antarctic geology and drift reconstructions, in Adie, R. J., ed., Antarctic geology and geophysics, Symposium on Antarctic geology and solid earth geophysics, Oslo, August 6-15, 1970: Internat. Union Geol. Sci., ser. B, no 1, p. $849-858$.

Ford, A. B., 1972, Fit of Gondwana continents-drift reconstruction from the Antarctic continental viewpoint: Internat. Geol. Cong., 24th, Montreal 1972, Proc., sec. 3, p. 113-121.

Halpern, Martin, 1971, Evidence for Gondwanaland from a review of west Antarctic radiometric ages, in Quam, L. O., ed., Research in the Antarctic: Am. Assoc. Adv. Sci. Pub. 93, p. 717-730.

Kellogg, K. S., and Rowley, P. D., 1974, Structural geology of the Lassiter Coast: Antarctic Jour. U.S., v. 9, no. 5, p. 224-225.

Laudon, T. S., 1972, Stratigraphy of eastern Ellsworth Land, in Adie, R. J., ed., Antarctic geology and geophysics, Symposium on Antarctic geology and solid earth geophysics, Oslo, August 6-15, 1970: Internat. Union Geol. Sci., ser. B, no 1, p. 215-223.

Laudon, T. S., Lackey, L. L., Quilty, P. G., and Otway, P. M., 1969, Geology of eastern Ellsworth Land, in Bushnell, V. C., and Craddock, Campbell, eds., Geologic maps of Antarctica: Am. Geog. Soc. Antarctic Map Folio Ser. 12, pl. 3.

Lovering, T. G., Cooper, J. R., Drewes, Harald, and Cone, G. C., 1970, Copper in biotite from igneous rocks in southern Arizona as an ore indicator, in Geological Survey research 1970: U.S. Geol. Survey Prof. Paper 700-B, p. B1-B8.

Lowell, J. D., and Guilbert, J. M., 1970, Lateral and vertical alteration-mineralization zoning in porphyry ore deposits: Econ. Geology, v. 65 , no. 4 , p. $373-408$.

Mehnert, H. H., Rowley, P. D., and Schmidt, D. L., 1975, K-Ar ages of plutonic rocks in the Lassiter Coast area, Antarctica: U.S. Geol. Survey Jour. Research, v. 3, no. 2, p. 233-236.

Meyer, Charles, and Hemley, J. J., 1967, Wall rock alteration, in Barnes, H. L., ed., Geochemistry of hydrothermal ore deposits: New York, Holt, Rinehart, and Winston, p. 166-235.

Nockolds, S. R., 1954, Average chemical compositions of some igne- ous rocks: Geol. Soc. America Bull., v. 65, no. 10, p. 1007-1032. Peacock, M. A., 1931, Classification of igneous rock series: Jour. Geology, v. 39 , no. 1 , p. 54-67.

Plummer, C. C., 1974, Contact metamorphism of the Latady Formation, southern Lassiter Coast, Antarctic Peninsula: Antarctic Jour. U.S., v. 9, no. 3, p. 82-83.

Rowley, P. D., 1973, Geologic observations on the northern Lassiter Coast and southern Black Coast: Antarctic Jour. U.S., v. 8, no. 4, p. 154-155.

Rowley, P. D., Farrar, Edward, and McBride, S. L., 1976, Preliminary interpretation of potassium-argon ages of plutons in northern Lassiter Coast and southern Black Coast: Antarctic Jour. U.S., v. 11, in press.

Rowley, P. D., and Williams, P. L., 1974, Plutonic rocks of the Lassiter Coast: Antarctic Jour. U.S., v. 9, no. 5, p. 225-226.

Rowley, P. D., Williams, P. L., Schmidt, D. L., Reynolds, R. L., Ford, A. B., Clark, A. H., Farrar, Edward, and McBride, S. L, 1975, Copper mineralization along the Lassiter Coast of the Antarctic Peninsula: Econ. Geology, v. 70, no. 5, p. 982-987.

Sillitoe, R. H., 1972, A plate tectonic model for the origin of porphyry copper deposits: Econ. Geology, v. 67, no. 2, p. 184-197.

-1973 , The tops and bottoms of porphyry copper deposits: Econ. Geology, v. 68 , no. 6 , p. $799-815$.

Thornton, C. P., and Tuttle, O. F., 1960, Chemistry of igneous rocks- [Pt.] 1, Differentiation index: Am. Jour. Sci., v. 258, no. 9, p. 664-684.

Wade, F. A., 1969, Geology of Marie Byrd Land, in Bushnell, V. C., and Craddock, Campbell, eds., Geologic maps of Antarctic: Am. Geog. Soc. Antarctic Map Folio Ser. 12, pl. 17.

Wahlstrom, E. E., 1947, Igneous minerals and rocks: New York, John Wiley and Sons, $367 \mathrm{p}$

Williams, P. L., 1970, Geology of the Lassiter Coast: Antarctic Jour. U.S., v. 5, no. 4, p. 98-99.

Williams, P. L., and Rowley, P. D., 1971, Geologic studies of the Lassiter Coast: Antarctic Jour. U.S., v. 6, no. 4, p. 120. 1972, Composition of Jurassic sandstones, Lassiter Coast: Antarctic Jour, U.S., v. 7, no. 5, p. 145-146.

Williams, P. L., Schmidt, D. L., Plummer, C. C., and Brown, L. E., 1972, Geology of the Lassiter Coast area, Antarctic Peninsula-preliminary report, in Adie, R. J., ed., Antaretic geology and geophysics, Symposium on Antarctic geology and solid earth geophysics, Oslo, August 6-15, 1970: Internat. Union Geol. Sci., ser. B, no. 1, p. 143-148. 

